\author{
UNIVERSIDADE DE SÃO PAULO
}

FACULDADE DE FILOSOFIA, LETRAS E CIÊNCIAS HUMANAS

DEPARTAMENTO DE LETRAS ORIENTAIS

PROGRAMA DE PÓS-GRADUAÇÃO EM LITERATURA E CULTURA RUSSAS

ELENA VASILEVICH

A composição da novela "Uma novela enfadonha" de Antón Tchékhov

São Paulo

2018 
UNIVERSIDADE DE SÃO PAULO

FACULDADE DE FILOSOFIA, LETRAS E CIÊNCIAS HUMANAS

DEPARTAMENTO DE LETRAS ORIENTAIS

PROGRAMA DE PÓS-GRADUAÇÃO EM LITERATURA E CULTURA RUSSAS

\section{ELENA VASILEVICH}

A composição da novela "Uma novela enfadonha" de Antón Tchékhov

Tese apresentada ao Programa de Literatura e Cultura Russa do Departamento de Letras Orientais da Faculdade de Filosofia, Letras e Ciências Humanas da Universidade de São Paulo para a obtenção do título de

Doutora em Letras

Orientador: Prof. Dr. Noé Silva de Oliveira Queiroz Policarpo Polli

São Paulo 
Nome: VASILEVICH, Elena

Título: A composição da novela "Uma novela enfadonha" de Antón Tchékhov.

Tese apresentada ao Programa de Literaura e Cultura Russa do Departamento de Letras Orientais da Faculdade de Filosofia, Letras e Ciências Humanas da Universidade de São Paulo para a obtenção do título de Doutora em Letras

Aprovada em:

Banca Examinadora

Prof. Dr. Noé Silva de Oliveira Instituição: DLO - FFLCH - USP

Queiroz Policarpo Polli

Assinatura:

Julgamento:

Profa. Dra. Elena Vássina

Instituição: DLO - FFLCH - USP

Julgamento:

Assinatura:

Profa. Dra. Maria Glushkova

Instituição:

FFLCH -USP

Julgamento:

Assinatura:

Prof. Dr. Euro de Barros Couto Júnior

Instituição: _EMASP (Escola municipal de administração de São Paulo)

Julgamento:

Assinatura:

Profa. Dra. Natalia Cristina Quintero Erasso

Instituição: Externo

Julgamento:

Assinatura: 


\section{AGRADECIMENTOS}

Agradeço especialmente a meu orientador, Prof. Dr. Noé Silva de Oliveira Queiroz Policarpo Polli pela orientação, paciência, revisões, ajuda na tradução do texto, e pela amizade.

Aos Professores Dra. Elena Vássina e Mário Ramos, que participaram da minha banca de qualificação, pelo incentivo e pelas sugestões que enriqueceram tanto este trabalho.

A cada um dos membros da banca examinadora, Profa., Dra. Elena Vássina, Dra. Maria Glushkova, Dra. Natalia Cristina Quintero Erasso, Dr. Euro de Barros Couto Júnior, pela sua generosa disposição em participar da avaliação de meu trabalho.

À minha família: aos meus pais, Vyacheslav e Era Mileniny, por sempre estarem ao meu lado, apesar das distâncias geográficas.

A todos os meus queridos amigos russos e brasileiros, pela paciência, inspiração e pelo apoio.

À CAPES, pela concessão da bolsa de doutorado e pelo apoio financeiro para a realização desta pesquisa. 


\section{RESUMO}

\section{Vasilevich. E. A composição da novela "Uma novela enfadonha" de}

Antón Tchékhov. 2017. 205 f. Tese (Doutorado) - Faculdade de Filosofia Letras e Ciências Humanas, Universidade de São Paulo, 2017.

O presente trabalho tem por objeto a análise da composição da obra "Uma novela enfadonha" de Antón Tchékhov.

O protagonista da novela é único dentro da criação tchekhoviana. Trata-se de um cientista de renome mundial que, ao enfrentar pela primeira vez a dúvida acerca da significância de sua própria existência, tenta resolver esse problema, tão doloroso para ele próprio, por meio de reflexões lógicas registradas em seu diário. Contudo, sofre um fracasso absoluto.

Redigida em primeira pessoa, nesta obra, como em toda a criação tchekhoviana, é característico um método de escrita objetivo, de tal forma que a opinião das personagens é, de fato, a opinião delas, e não representa o parecer do autor. É possível compreender a posição de Tchékhov na novela, onde não há uma única palavra direta do autor, apenas pela observação de certos sinais expressos no subtexto. A partir disso, analisamos aqueles sinais que constituem os elementos estilísticos básicos da composição - partes do enredo que incluem o tempo presente e as recordações, o léxico, os temas da morte, a natureza, os animais, a música, além dos detalhes, símbolos, ritmo, a caracterização das personagens e o cronótopo. Mostramos como todos esses elementos, ao se entrelaçarem e realçarem uns aos outros, conformam o subtexto da obra, e contribuem para a realização da ideia central do autor: mostrar a situação psicológica da pessoa quando sua vida se aproxima do fim, quando é levantada a questão do sentido último e concreto da vida humana, no pano de fundo do processo histórico infinito.

Além disso, examinamos a história da criação da novela, observando esse processo por meio da análise das cartas do autor. Também ponderamos os trabalhos da crítica dedicados a "Uma história enfadonha" em diversos momentos históricos de estudo da obra.

Palavras-chave: 1. Literatura russa 2. Antón Tchékhov 3. Composição 4. Subtexto 5. Simbologia 


\section{ABSTRACT}

\section{VASILEVICH. E. The Composition of the Short Story "A Dreary}

Story" by Anton Chekhov. 2017. 205 pag. Thesis (PhD) - Faculty of Philosophy, Languages, Literature, and Human Sciences (FFLCH), São Paulo University, 2017.

The purpose of this work is to study the composition of the Chekhov's novel "A Dreary Story". The main character of this novel is unique for Chekhov since he is a World known scientist. Being in doubt for the first time about the meaning of his life he is trying to resolve this painful problem with the help of logical reflections in his diary - but fails. The novel has the form of a narrative of the main character. In Chekhovs' writings the opinion of the character never reflect the opinion of the author. Therefore, to understand the Chekhov point of view in a novel that does not contain single word directly from the author, one has to be attentive to special signs in the subtext. We analyze these signs, that are main stylistic elements of the composition such as the plot, the narrative in the present and in recollections, the lexis, the themes of death, of nature, of animals, musics, as well as the details, symbols, the rhythm, the characters and the chronotop. We show that all these factors interact and clarify each other to compose the subtext of the novel. They conspire to underline the main idea of the author to show the psychology a man when his life is coming to an end and then he is concerned with the meaning of his particular finite life at the background of an infinite historic process. Besides, we consider the history of creation of "A Dreary Story" by looking at the author's correspondence and analyzing the critics dedicated to the novel.

Keywords: 1. Russian Literature 2. Anton Chekhov. 3. Composition 4. Subtext 5. Symbols 


\section{Аннотация}

Василевич Е. Композиция повести А. Чехова «Скучная история». 2017. 205 f. Диссертация на соискание ученой степени кандидата филологических наук - Факультет Философии, Филологии и Гуманитарных Наук Университета Сан-Пауло. 2017.

Целью представленной работы является исследование композиции повести А. Чехова "Скучная история". Персонаж этой повести уникален для творчества Чехова - это ученый с мировым именем. Столкнувшись впервые с сомнением в значимости собственной прожитой жизни, он пытается разрешить эту болезненную для себя проблему с помощью логических размышлений в своем дневнике, однако, терпит полный крах. Повесть написана от 1-го лица, а так как для всего творчества Чехова характерен объективный метод письма, когда мнение героя является только его мнением и не выражает авторскую точку зрения, чеховскую позицию в повести, где нет ни одного прямого авторского слова, возможно понять только обращая внимание на особые знаки, выраженные в подтексте. Исходя из этого мы анализируем эти знаки - основные стилистические элементы композиции, такие, как сюжетные линии, включающие линию настоящего времени и воспоминаний, лексику, темы смерти, природы, животных, музыки, а также детали, символы, ритм, характеристику персонажей и хронотоп и показываем, как все они, сплетаясь и подчеркивая друг друга, составляют подтекст произведения и работают на основную мысль автора - показать психологическое состояние человека в тот момент, когда его жизнь подходит к концу, когда встает вопрос о смысле конечной, конкретной человеческой жизни на фоне бесконечного исторического процесса. Кроме этого, мы рассматриваем историю создания повести, прослеживая этот процесс по письмам писателя и анализируем критику, посвященную "Скучной истории" в различные исторические периоды ее изучения.

Ключевые слова: 1. Русская литература 2. А. П. Чехов 3. Композиция 4. Подтекст 5. Символика 


\section{Índice}

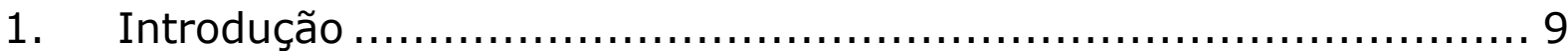

2. História da criação da novela (cartas 1888 - 1889) ......................13

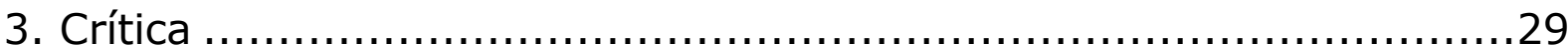

4. Elementos da composição da novela .......................................41

4.1 Conceito geral de composição duma obra literária ....................41

4.2 Título, subtítulo .................................................... 43

4.3 A composição dos apontamentos - desenvolvimento das reflexões e

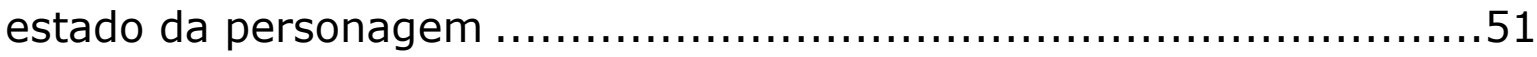

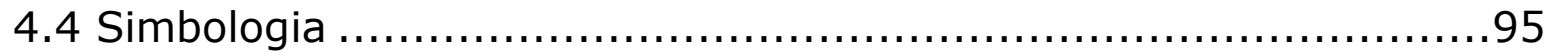

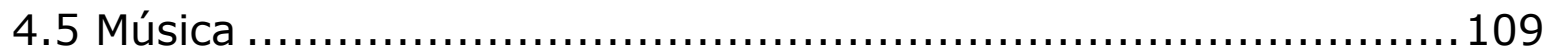

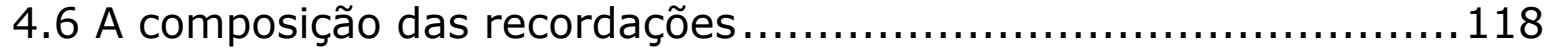

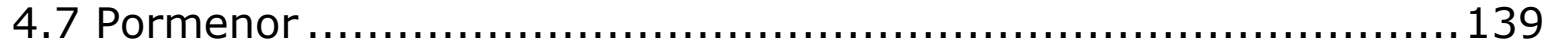

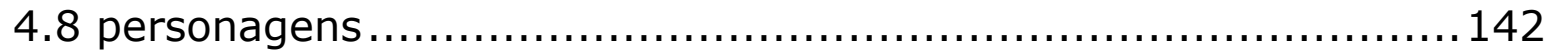

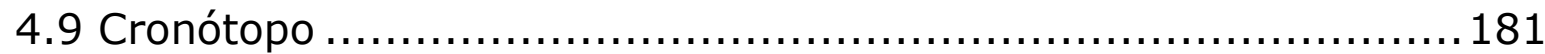

5. Conclusão .............................................................. 194

6. Bibliografia .............................................................. 195

6.1 Obras de A. P. Tchékhov ......................................... 195

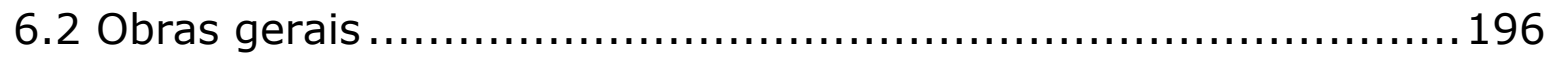

7. Anexo .................................... Erro! Indicador não definido. 


\section{Introdução}

O trabalho inclui uma breve exposição da história da escrita da novela, com base em cartas do autor, escritas em 1889, um exame da crítica, composta de três partes (crítica anterior à Revolução de Outubro, soviética e do nosso período contemporâneo de estudo da obra do escritor e, concretamente, de "Uma História Enfadonha") e uma análise nossa da composição da novela, dedicada a questões de estilística, a símbolos, às personagens e às suas particularidades espaciais e temporais.

A maneira artística, elaborada por Tchékhov por volta do fim dos anos 1880, foi um descobrimento para todos e determinou em muito a orientação da literatura mundial do século vinte. Os meios artísticos, que auxiliam o leitor a compreender mais profundamente o pensamento do autor, começam a desempenhar novos papéis nos textos de Tchékhov. A partir da metade do decénio de oitenta do século 19, Tchékhov faz uso de vários procedimentos, escondendo, no fundo do texto, os seus juízos, os verdadeiros sentimentos das personagens, o estado psicológico delas e as relações de umas com as outras. A posição do autor, assim, é quase imperceptível, o que é notado sobretudo na sua dramaturgia. As suas rubricas, pausas, diálogos semelhantes a monólogos que permitem comunicar os mínimos matizes dos sentimentos e pensamentos das personagens e, muitas vezes, não estão ligados entre si nem com a ação, como que vão para segundo plano, sobre o fundo do crescente papel dos sons e silêncios, da iluminação, da mudança da hora do dia ou da estação do ano, da cor da roupa etc. As palavras perdem o significado próprio, rompem os seus nexos lógicos e são percebidas como enganadoras pelo leitor ou espectador. Ao mesmo tempo, o meio que circunda as personagens, com todos os seus atributos - luz, cheiro, sons familiares ou inesperados, como o duma corda rompida ou o crepitar de fogo, a mímica involuntária das personagens, um verso de canção ou poema que se repita cá e lá etc. - agora, ao contrário, torna-se a única realidade artística, a "corrente subterrânea", o subtexto que permite compreender a 
ideia e intenção do autor.

É sabido que a determinação da posição do autor, nas obras de Tchékhov, em geral, é difícil e suscita muita discordância entre os estudiosos. É particularmente difícil fazê-lo nas suas peças, nas quais, de acordo com o género dramático, inexiste uma genuína narrativa do autor. Os pesquisadores têm, com ressalvas, de recorrer a uma aproximação da posição do escritor à posição duma personagem ou outra, isto é, buscar algum tipo de indivíduo filosofador. Toda a tentativa dessas, até aquela baseda em coincidências textuais com declarações do escritor, tem sob si uma base muito precária. Deve dar-se atenção não apenas a este ou àquele dito da personagem, senão também ao modo como o autor o encara. ${ }^{1}$

Os estudiosos dedicaram-se muito menos ao tema do subtexto tchekhoviano na sua prosa, e esse campo permanece pouco estudado até hoje, embora represente um material riquíssimo. O autor está como que dissolvido no texto, e até nos contos e novelas, em que se tem um patente texto autoral, é impossível identificá-lo com a posição do próprio Tchékhov; o narrador está presente mais como mais uma personagem. "Uma História Enfadonha" pertence àquelas obras tchekhovianas, em que enxergar a posição do autor é ainda mais complicado do que na dramaturgia, uma vez que foram escritas em nome duma personagem; nelas, não há nem rubricas do autor. Tanto mais importante e interessante é analisar como o "subtexto" revela a profundidade do conteúdo, o modo do autor de encarar a personagem, a situação e os temas tratados na novela, o papel desempenhado pelos pormenores "fortuitos", a composição, as digressões da linha composicional básica, as recordações, o léxico, a estilística, o espaço e o tempo na novela, e, tendo feito isso, examinar como todos esses meios, reunindo-se em um sistema artístico uno, levam à decifração do subtexto tchekhoviano.

No nosso trabalho, nós nos basearemos em estudos clássicos e novos (A.Tchudakov, I.Sukhih, V.Katáev e outros).

${ }^{1}$ S. KUZNETSOV , Russkaja literatura, 1985, № 1,p.146 
No início dos anos 1880, em substituição ao conhecido autor de contos humorísticos, Antocha Tchekhonté ${ }^{2}$ de seu nome, vem o já famoso Antón Tchékhov com uma estilística já constituída e uma nova maneira de encarar a prosa e a dramaturgia, as quais, inicialmente, não foram compreendidas e valorizadas pelos contemporâneos e ainda constituem objeto de muitos estudos. Uma das principais dificuldades da compreensão de Tchékhov consiste no seu modo peculiar de encarar o papel do autor na obra. À diferença dos seus grandes predecessores e contemporâneos (Tolstói, Dostoiévski, Turgueniev), ele não declara as suas opiniões e não coloca o seu modo de ver a vida, as pessoas e os problemas mais importantes do seu tempo nos lábios das suas personagens. O que estas dizem ou pensam, os juízos que emitem, as suas ilusões, falsidade, inclusive a involuntária, tudo isso pertence somente a elas.

... o mundo representado passa inteiramente pelo prisma da percepção da personagem principal. Desenha-se apenas o que ele sente, vê e sabe. O microcosmo de um tal conto torna-se o mundo percebido pelas personagens. Essa capacidade da narrativa tchekhoviana de transformar-se em personagem foi notada já pelos contemporâneos do escritor. ${ }^{3}$

Tchékhov defendeu essa sua posição em cartas tanto a Suvórin, quanto a jovens literatos, considerando-a uma questão de princípios.

Como compreender o famoso e misterioso "subtexto" tchekhoviano? Por que sinais se pode extrair informação dele?

O objeto do nosso estudo é a novela "Uma História Enfadonha", de 1889. A escolha de precisamente essa obra foi ditada pelos seguintes fatores:

1) a época da sua escrita;

${ }^{2}$ O pseudónimo mais difundido de A. Tchékhov no período inicial da sua obra

${ }^{3}$ A.TCHUDAKOV, M.,1971, p.48 
2) os meios artísticos, empregados na novela, foram pouco estudados; 3) ela foi escrita em primeira pessoa. 


\section{História da criação da novela (cartas 1888 - 1889)}

"Uma História Enfadonha" ("Скучная история") foi primeiramente publicada em 1889, na edição de Novembro da revista O Mensageiro do Norte (Северный вестник), e em 1890 foi incluída na coletânea "Gente Carrancuda" ("Хмурые люди"). A essa altura, Tchékhov não apenas era já um famoso e apreciado autor de contos humorísticos, como também dera mostras de ser um escritor profundo, um dos mais lidos na Rússia de então. Da sua pena haviam já saído obras expressivas, entre as quais os contos "Егерь", "Злоумышленник","Тоска", "Каштанка", "Спать хочется", "Огни", а рес̧а "Иванов" е a novela "Степь". Muitas questões e temas, evidenciados em "Uma História Enfadonha", haviam já sido aventados, duma forma ou outra, nessas obras anteriores, mas a maneira particular de ver os acontecimentos representados, a posição de Tchékhov em relação a eles e às personagens, incomum para a literatura do seu tempo, o estilo de Tchékhov e a especial maneira "objetiva" de escrita, podemos dizê-lo, estavam já formados, constituídos. Isso foi notado, embora nem sempre corretamente compreendido, ainda ao tempo de Tchékhov e permitiu aos críticos de então definir o período 1889-1890 como de viragem na estilística tchekhoviana. Lugar central, no referido período, é ocupado por "Uma História Enfadonha".

Um dos mais importantes fatos biográficos, que serviram de base para a escrita da novela, talvez tenha sido a formação médica, obtida por Tchékhov na Universidade de Moscou, não apenas por a personagem principal ser um catedrático de Medicina e à universidade serem dedicadas muitas páginas das suas memórias, senão também porque a formação recebida despertou no jovem literato o interesse pela psiquiatria e psicologia do seu tempo (principalmente no que se refere ao tema da relação entre os sexos), pela filosofia antiga e da época, pelos descobrimentos no campo das Ciências Naturais e, principalmente, pelo "tratamento científico" da criação artística, o qual se manifesta de modo 
particularmente expressivo em "Uma História Enfadonha". Tudo isso não somente se refletiu na novela, como também determinou em muito a representação das situações e do mundo interior das personagens, a qual é psicologicamente exata tanto sob a ótica dum escritor, quanto sob a ótica dum cientista médico. Tchékhov teve, como professores na universidade, os fundadores da psiquiatria russa: Zakhárin, Babúkhin e Sklifossóvskii. Ele próprio considerava a sua formação médica como o fator decisivo para a sua decisão de tornar-se escritor.

Em 1900, em breve autobiografia, ele escreve:

"Não tenho dúvidas, o exercício das ciências médicas tiveram séria influência na minha atividade literária; ele ampliou significativamente o campo das minhas observações e enriqueceu os meus conhecimentos, cujo verdadeiro valor para mim como escritor só poderá entender quem também for médico; ele teve, também, uma influência definidora de rumos, e, provavelmente, graças à minha proximidade à Medicina, eu consegui evitar muitos erros. O conhecimento das ciências naturais sempre me manteve alerta, e eu esforcei-me, onde fosse possível, por proceder conforme os dados científicos e, onde era impossível, preferia simplesmente não escrever. Direi, a propósito, que as condições da criação artística nem sempre permitem inteira harmonia com os dados científicos; não se pode representar, no palco, a morte por envenenamento tal qual ela ocorre na realidade. Mas deve sentir-se harmonia com os dados científicos também nessa convencionalidade, ou seja, é preciso que ao leitor ou espectador fique claro que isso é apenas uma convencionalidade e que ele está diante dum escritor entendido. Aos literatos que encarem a ciência negativamente, eu não pertenço; e àqueles que a tudo cheguem pela própria razão, eu não gostaria de pertencer. ${ }^{4}$

\footnotetext{
${ }^{4}$ A.TCHÉKHOV, Moscou, 1979, p.271
} 
Tendo resolvido dedicar a P. I. Tchaikovskyi a coletânea de contos "Gente Carrancuda", na qual o lugar central cabe a "Uma História Enfadonha", Tchékhov escreve ao compositor, mencionando "elementos médicos":

"Neste mês, eu pretendo começar a publicar um novo livro de contos; eles são tediosos e maçadores, como o Outono, monótonos pelo tom, e elementos artísticos, neles, estão densamente misturados com médicos, mas isso, apesar de tudo, não me tira a ousadia de dirigir-me ao senhor com um pedido encarecido: permita-me dedicar-Ihe este livro." 5

No estudo da novela, nós não deixaremos de levar tal aspecto em conta.

Claro está, entre as premissas mais importantes de muitos temas, nela tratados, também estão as obras literárias, às quais o autor remete 0 leitor muito discretamente. Entre elas, os críticos costumar citar "A Morte de Ivan Ilitch", de Tolstói, "O Aluno", de Bourget (Paul Charles Joseph Bourget foi um romancista e crítico literário francês, autor de romances psicológicos. Bourget exerceu grande influência nas letras francesas no período que antecedeu o naturalismo, o qual combateu.), e "Fausto", de Goethe. No texto, há muitas referências a outros autores, sobretudo Shakespeare e Marco Aurélio, o que também foi assinalado pela crítica. Bem como muitas reminiscências, o que, com outros meios artísticos, nos permite procurar uma chave para o "subtexto" tchekhoviano. Basta enumerar os nomes de cientistas, escritores, personagens literárias, filósofos e músicos, mencionados na novela (com a concisão da escrita de Tchékhov, embora!) para falarmos da necessidade dum estudo esmerado desse material (Shakespeare, Marco Aurélio, Epíteto, Pascal, Pirogov, Nekrássov, Skóblev, Perov, Hekuba, Bach, Bhrams e outros). Infelizmente, esse interessantíssimo tema está pouco estudado.

\footnotetext{
5 P. TCHAIKOVSKY $12 \quad 10$ 1889 г. Disponivel em:http://chehov.niv.ru/chehov/letters/18881889/letter-696.htm
} 
A nosso ver, são importantes não somente os aspectos históricos, filosóficos ou literários da menção a tais nomes, senão também outros, igualmente importantes.

Nós tentaremos mostrar que, na novela, as reminiscências estão intimamente ligadas às noções de tempo e espaço e determinaram em muito a composição da obra.

É difícil falar de quando a Tchékhov veio a ideia de escrever "Uma História Enfadonha", mas, em algumas cartas de 1888-1889, encontramse menções a ideias usadas nela. A primeira menção concreta acerca da futura obra está em carta a A. Evréinova, de 10 de Março de 1889. A ideia era de que seria um conto.

"Eu tenho um enredo para um conto não muito grande. Tentarei fazê-lo para o livro de Maio ou Junho. "6

É sabido que, em Março de 1889, realiza uma viagem a Khárkov, e essa cidade tornar-se-ia um dos lugares da ação da novela. Precisamente nesse período, a Primavera de 1889, ele lê o livro "Meditações", do estóico Marco Aurélio, e faz notas à margem. O referido livro conserva-se na casa-museu de Ialta, e nós tivemos a oportunidade de manuseá-lo em 1983. Na obra subsequente do escritor, o tema do estoicismo aparecerá mais de uma vez, especialmente em "Enfermaria № 6".

Se examinarmos as cartas de Tchékhov, escritas no período que vai dos fins de 1888 aos de 1889, poderemos notar como mudaram o seu estado de espírito e a sua percepção do mundo.

Do fim de 1888 ao início de 1889, ele está feliz, agitado e cheio de idéias de criação e constrói planos. Recebera, pouco tempo antes, o prémio Púchkin e estava, bem como os seus parentes e amigos, muito comovido e orgulhoso do fato. Em Peterburgo, é encenado "Ivánov", com a sua ativa participação nos ensaios. Para além disso, ele está a escrever

\footnotetext{
${ }^{6}$ A. IEVREÍNOVA 10.031889 г. Москва. Disponivel em:http://chehov.niv.ru/chehov/letters/1888-
} 1889/letter-619.htm 
um romance, que nunca seria concluído, mas cuja idéia o arrebatara naquele período, fato testemunhado por cartas (muito seria usado em outras obras, entre as quais "Uma História Enfadonha").

A partir de Março de 1889, a situação começa a mudar, com o adoecimento do seu irmão Nikolai; o que, incialmente, não parecia muito grave (febre tifóide), transforma-se em tísica com desfecho fatal em Junho. Em quase todo o período de doença do irmão, Tchékhov tem-no consigo; depois, toda a família vai para a datcha de Súmy, e o falecimento do jovem pintor ocorre durante uma breve ausência do escritor.

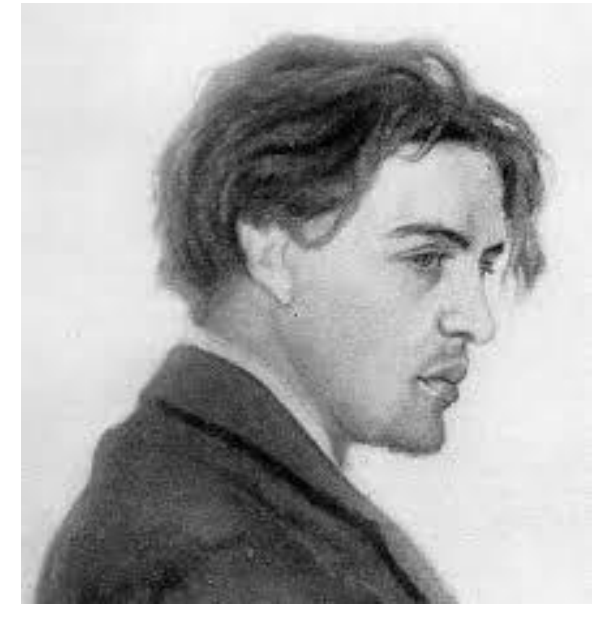

A.Tchékhov N.Tchékhov

À medida do desenrolar dos trágicos acontecimentos, as cartas vão tornando-se, a cada vez, mais desassossegadas, e sente-se a depressão mais claramente; surge a palavra "скучно" ("é tedioso"), precisamente no sentido, em que será usada no título da novela. Às vezes, melhorava o estado de Nikolai e surgia, então, a esperança, e o tom das cartas novamente mudava. Aparecem, nelas, referências a Marco Aurélio, Epíteto, Salomão, Goethe, Fausto e Bourget. Encontram-se reflexões acerca de psicologia, materialismo, filosofia e indiferença, entre outras coisas, e a maioria desses temas encontraria reflexo na futura novela. Ao meio de Maio, fica claro que Nikolai não teria cura.

Escreve Tchékhov a Suvórin, em 14 de Maio:

O meu pintor nunca recobrará a saúde. Ele está com tísica. A 
questão está colocada assim: quanto durará a doença? ${ }^{7}$

\section{A Léikin, em 22 de Maio:}

... nos meus braços, tenho Nikolai, doente de tísica e consumido por ela. É péssimo, o seu estado, e péssimo, também o meu, e o senhor pode imaginar a minha situação. Não vou estender-me. ${ }^{8}$

Nikolai morreria em 17 de Junho.

Escreve Tchékhov a Plechtchéev, em 26 de Junho:

"O pobre pintor morreu. (...) Era impossível dizer quando Nikolai morreria, mas que isso seria logo, para mim estava claro. O desfecho ocorreu nas seguintes circunstâncias. Na minha casa estava hospedado o Svobódin. Aproveitando a vinda do meu irmão mais velho, que poderia substituir-me, eu quis descansar, respirar outro ar durante uns cinco dias; convenci Svobódin e os Lintarióv e fui com eles à província de Poltava, à casa dos Smáguinin. Como castigo pela minha partida, no caminho todo soprou um vento tão frio e esteve o céu tão carregado, que parecia bem a tundra. Na metade do caminho, começou a chover. Chegamos de noite à casa dos Smáginins, molhados e com frio, deitámo-nos em camas frias e adormecemos com o barulho da chuva. De manhã, o mesmo tempo revoltante de Vólogda; a vida inteira, eu não conseguirei esquecer nem a estrada lamacenta, nem o céu cinzento, nem as lágrimas nas árvores; digo - não conseguirei, porque de manhã veio de Mírgorod um mujique baixote, trazendo um telegrama molhado:

"Kólia morreu". Pode imaginar o meu estado de espírito. Foi preciso galopar de volta à estação, tomar a ferrovia e gastar oito horas em espera nas estações... Em Rómny, eu esperei das 7

\footnotetext{
7 A. SUVORIN 14.031898 disponivel em: http://chehov-lit.ru/chehov/letters/1888-1889/letter653.htm

8 H.LÉIKIN 22.051889 disponivel em: http://chehov-lit.ru/chehov/letters/1888-1889/letter656.htm
} 
horas da noite até às duas da madrugada. De tédio [grifo meu - E. V.] fui vadiar pela cidade. Lembro-me: sento-me num jardim, escuridão, um frio de lascar, um tédio monstruoso [Idem], e, atrás da parede castanho-acizentada, perto da qual eu estava sentado, artistas ensaiavam um melodrama.

Em casa, encontrei o sofrimento. A nossa casa até então não conhecera a morte, e vimos um caixão pela primeira vez". ${ }^{9}$

Em 2 de Julho, comunica a Suvórin:

"O pobre Nikolai morreu. Eu estupidifiquei-me e estou baço. Um tédio dos infernos, nem um nadinha de poesia na vida, ausência total de desejos etc. etc." 10

A 18 de Julho, à irmã Macha:

"Um tédio dos infernos, e talvez eu parta daqui amanhã ou depois de amanhã". 11

E a 3 de Agosto a Plechtchéev:

"Partindo, deixei em casa o tédio desalentado e o medo". ${ }^{12}$

Já pelas cartas vê-se que o conceito de "tédio" ("скука") está, para Tchékhov, intimamente ligado com o estado de desespero e tristeza ("скука аспидская" - tédio monstruoso; "скука адская", tédio dos infernos).

\footnotetext{
9 A. PLECHTCHEEV $26 \quad 06 \quad 1889$ disponivel em:http://chehov.niv.ru/chehov/letters/18881889/letter-664.htm

10 A.SUVORIN $2.07 \quad 1889$ : disponivel em:http://chehov-lit.ru/chehov/letters/1888-1889/letter665.htm

11 M. TCHÉKHOVA $18 \quad 07 \quad 1889$ disponivel em http://chehov.niv.ru/chehov/letters/18881889/letter-668.htm

12 A. PLECHTCHEEV $3 \quad 081889$ disponivel em http://chehov.niv.ru/chehov/letters/18881889/letter-669.htm
} 
Tal acontecimento, subentende-se, não apenas atrasou o presumível término do conto, mas também, e principalmente, influenciou o tom de espírito da novela e o tema, que a atravessa como motivo dominante - o tema da morte. Tal como o autor, que acabara de, pela primeira vez, passar pela tragédia da perda dum ente querido, com ser o médico do irmão e um observador diário do desenvolvimento da doença, estando ele próprio acometido da mesma moléstia (a primeira hemoptise ocorrera-Ihe em 1884 e repetira-se no fim de 1888), da mesma forma a personagem sabe que morrerá logo e, ao verificar os sintomas da doença fatal e a observar-lhe o desenvolvimento, estabelece o prazo que lhe resta, provando, simultaneamente, todo o terror de quem tenha tomado consciência do seu fim próximo.

Precisamente isso constitui o ponto de partida das reflexões da personagem, que se tornam a linha principal da composição da novela.

A morte próxima está indissociavelmente ligada ao tema do tempo de que a pessoa não dispõe.

A 16 de Julho, Tchékhov parte para Ialta e do navio escreve ao seu irmão Ivan:

"Eu vou para Ialta e decididamente não sei para que ali vou. É preciso ir também ao Tirol, a Constantinopla, a Súmy; todos os países misturaram-se na minha cabeça, a fantasia fervilha de cidades, e eu não sei qual escolher..." 13

Comparêmo-lo com a viagem de Nikolai Stepánovitch a Khárkov:

"Se é para ir para Khárkov, que seja para Khárkov. Além do quê, nos últimos tempos, eu estou tão indiferente a tudo, que para mim dá no mesmo ir para Khárkov, Paris ou Bérditchev". ${ }^{14}$

\footnotetext{
${ }^{13}$ И.TCHÉCKHOV 16.071889 disponivel em:https://royallib.com/read/chehov_anton/tom_21_pisma_1888_1889.html\#778240

${ }^{14}$ A.TCHÉKHOV Moscou, 1977, p.304
} 
O primeiro título da novela era "O meu Nome e eu" ("Мое имя и я"), o que, à primeira vista, é muito mais consonante com a ideia principal da narrativa, mas, no entanto, em Setembro de 1889, Tchékhov intitula-a "Uma História Enfadonha" e, apesar da advertência de Pleschtchéev de que o novo título poderia provocar a ironia dos detratores, recusou-se terminantemente a mudá-lo.

No capítulo dedicado ao título e ao subtítulo ("Из записок старого человека", "Notas de um Velho"), nós tentaremos provar o caráter de síntese simbólica do título mantido por ele. Alguns pesquisadores estudaram já a questão do conceito de "tédio" na obra de Tchékhov e, claro, também em "Uma História Enfadonha", mas não foi notada a palavra "história" ("история"), que tem vários significados na língua russa e, na nossa opinião, adquire o mais amplo sentido no título da novela, o que está diretamente relacionado com os conceitos de "tempo" e "espaço".

Assim, no "mais infame dos estados de espírito", Tchékhov chega a Ialta e trabalha na novela, que seria concluída somente no Outono. Simultaneamente, escreve a peça "O Silvano" ("Леший"), mais tarde reescrita como "Tio Vánia" ("Дядя Ваня").

Por alguns testemunhos, é possível falar dum suposto protótipo da personagem principal (levando em conta, obviamente, a convencionalidade do conceito de "protótipo"). É Aleksandr Ivánovitch Babúkhin, catedrático da Universidade de Moscou. Isso foi confirmado pelo próprio Tchékhov:

É um vulto coletivo, embora muito tenha sido tomado de Babúkhin. Coincidem alguns traços exteriores: em 1889, Babúkhin, como Nikolai Stepánovitch, tinha 62 anos; tivera encontros com Pirogov nos anos 1860, como o professor de "Uma História Enfadonha"; apesar de defeitos de fala, possuía as mesmas brilhantes capacidades de orador, sabendo, pelas palavras dum orador, "desenhar em figuras vivas as coisas mais 
abstratas... e iluminar tudo isso com um humor muito vivo, entusiástico, e contar coisas com um talento incomparável. ${ }^{15}$

No relato da história da criação da novela, não se pode esquecer o fato de que ela foi escrita com grande dificuldade, do que há muitos testemunhos nas cartas do período de trabalho nela.

A 3 de Agosto, Tchékhov escreve a Plechtchéev:

"... o conto está quase pronto. Apesar do calor e das tentações de Ialta, eu escrevo. O que escrevi já dá uns 200 rublos, isto é, uma folha de impressão inteira... Por força do calor e do meu nojento, melancólico estado de espírito, o conto tem-me saído um tanto tedioso. Mas o motivo é novo. É bem possível que o leiam com interesse". ${ }^{16}$

Tchékhov, no entanto, ficaria insatisfeito com o que escrevera e, adiando a entrega do manuscrito à revista, põe-se a retrabalhá-lo.

A 3 de Setembro, de novo a Plechtchéev:

"Escrevi hoje a Anna Mikháilovna que o conto para o "Mensageiro do Norte" já está pronto, e pedi-Ihe permissão para retê-lo em casa e não enviá-lo até ao próximo livro. Eu quero polir e embelezar uma coisa e outra e, principalmente, pensar um pouco nelas. Eu nunca na vida escrevi algo parecido, os motivos são completamente novos para mim, e eu temo que a minha inexperiência me faça quebrar a cara. Mais exatamente, eu temo escrever alguma asneira". ${ }^{17}$

\footnotetext{
${ }^{15}$ A.TCHÉKHOV, Moscou, 1977, p.671

${ }^{16}$ A. N.PLESCHTCHHEEV 3.08

1889https://royallib.com/read/chehov_anton/tom_21_pisma_1888_1889.html\#798720

17 A. N.PLESCHTCHEEV 309 1889https://royallib.com/read/chehov_anton/tom_21_pisma_1888_ 1889.html\#819200
} 
Depois, ele volta a Moscou e a 7 de Setembro escreve a Evréinova (redatora):

Tendo-Ihe enviado a carta, eu acalmei-me e, entregue ao acabamento do meu conto, escagalhei-o de ponta a ponta e joguei fora um pedaço do meio e o final inteiro, decidido a substituí-los por novos. Que fazer agora? Não posso enviar-lhe o que me parece inacabado e que não me agrada. A coisa por si, pela sua natureza, é meio tediosa, e, se eu não me ocupar dela atentamente, então pode ser que, como dizem os franceses, o Diabo é que sabe o que vai sair... O enredo do conto é novo: a vida dum velho professor catedrático, conselheiro privado. Está difícil escrever. Volta e meia, é preciso refazer páginas inteiras, pois todo o conto está estragado pelo detestável estado de espírito, de que eu não consegui livrar-me no Verão todo. Ele, provavelmente, não agradará, mas que ele fará barulho e que o "Pensamento Russo" vai massacrá-lo, disso eu estou convencido". 18

\section{A 13 de Setembro, escreve a Tíkhonov:}

"Concluí uma extensa novela. É uma coisa pesada, portanto pode matar alguém. Pesada não pela quantidade de folhas de impressão, mas pela qualidade. É uma coisa canhestra e volumosa. Trato um motivo novo". 19

Ao dia seguinte, ele fala novamente a Pleschtchéev da dificuldade de escrever:

"... imagine o senhor Tchékhov, que escreve, sua e corrige,

${ }^{18}$ А. М. ЕВРЕИНОВОЙ 7 сентября 1889

https://royallib.com/read/chehov_anton/tom_21_pisma_1888_188 9. html\#819200

${ }^{19}$ B. TIKHONOV 13.091889

https://royallib.com/read/chehov_anton/tom_21_pisma_1888_1889.html\#839680 
e vê que, com as mudanças e horrores revolucionários, a novela sofre sob a sua pena e não fica nem um tiquinho melhor. $O$ que faço não é escrever, mas promover perturbações. Em tal estado de espírito, concorde comigo, não é lá adequado apressar-se com a publicação.

Na minha novela, não há dois estados de espírito, mas quinze inteiros... tenho a esperança de que o senhor verá nela duas ou três pessoas novas, interessantes para qualquer leitor inteligente; verá uma ou duas novas situações... " 20

A Leóntiev-Chtcheglov, a 18 de Setembro:

"Estou a braços com a novela, e a azáfama está no fim. Daqui a uns cinco dias, este pesado disparate irá para Peterburgo, para a tipografia de Demakov. Isso não é uma novela, mas uma tese de doutorado. Cairá no gosto apenas dos amantes da leitura tediosa e pesada, e eu faço mal em não mandá-la para a "Revista de Artilharia" («Артиллерийский журнал»). ${ }^{21}$

A novela foi concluída a 24 de Setembro, o que testemunham cartas a Evréinova e Plechtchéev de 24 de Setembro:

"Envio-Ihe o conto, "Uma História Enfadonha (Notas dum Velho)". A história é de fato tediosa, e está contada sem arte. Para escrever notas dum velho, é preciso ser velho, mas tenho lá culpa de ser jovem?" 22

Nessa mesma carta, Tchékhov escreve também que não Ihe importa se aquilo será uma novela ou um conto.

\footnotetext{
${ }^{20}$ A. N.PLESCHTCHEEV 14091889

https://royallib.com/read/chehov_anton/tom_21_pisma_1888_1889.html\#839680

${ }^{21}$ и. Л. LEONT'EV-CHTCHEGLOV 18091889

https://royallib.com/read/chehov_anton/tom_21_pisma_1888_1889.html\#860160

${ }^{22}$ A. EVREINOVA 24091889

https://royallib.com/read/chehov_anton/tom_21_pisma_1888_1889.html\#860160
} 
É pouco provável que Tchékhov estivesse insatisfeito com a sua novela, enviando-a a uma revista e a uma coletânea, mas, pelas cartas, pode notar-se que estava muito inseguro quanto à reação dos leitores. Por que duvidava um escritor famoso e reconhecido de que o entenderiam? Por que the fora tão difícil o trabalho de escrevê-la, por que the dera outra composição e mudara o título? Por que escreve que o motivo the era completamente novo e que não escrevera algo semelhante "desde que nascera", se, em obras anteriores, haviam já sido tratados os seus temas principais - morte, busca duma concepção do mundo, isolamento e incompreensão mútua de pessoas próximas? Quais eram os tais quinze estados de espírito?

Ainda em manuscrito, a novela foi lida por Pleschtchéev e Suvórin, que encontraram "notas" tchekhovianas nas reflexões do professor. O primeiro ficou encantado:

"O Sr. não teve nada tão poderoso e profundo, quanto essa novela... E não falo já da absoluta novidade do motivo". ${ }^{23}$

Tchékhov recebeu com respeito as observações, feitas por Plechtchéev, e, na carta de resposta, "tira um pouco o véu" à sua personagem e a alguns aspectos da composição.

Muito obrigado pela carta e pelas indicações, que não deixarei de aproveitar quando eu ler as provas. Apenas em poucas coisas não concordo com o senhor. Por exemplo, acho que não convém mudar o título da novela - os velhacos que, de acordo com suas previsões, irão caçoar de "Uma História Enfadonha" são tão desprovidos de espírito, que não há motivo para temê-los; e se alguém fizer uma piada bem-sucedida, ficarei satisfeito por lhe ter dado essa opurtunidade. O professor não pode escrever acerca do marido de Kátia, porque não o conhece, e Kátia não diz nada a respeito dele; além do mais, o meu herói - e isto constitui um dos

${ }^{23}$ A.TCHÉKHOV ,1977, c. 672 
seus traços principais - trata com demasiada negligência a vida interior dos que o rodeiam, e enquanto, ao seu lado, choram, erram, mentem, ele, com a maior tranquilidade, discorre acerca de teatro e literatura. Se ele fosse de outro tipo, talvez Lisa e Kátia não se tivessem perdido.

Realmente, o passado de Kátia saiu longo e enfadonho. Mas não dá para fazer de outra forma. Se eu tivesse tentado tornar essa passagem mais interessante, há de concordar que a minha novela sairia duas vezes mais longa...

Uma novela, como também o palco, impõe suas condições. Portanto, a intuição diz-me no final duma novela ou dum conto eu devo concentrar artificialmente no leitor a impressão de toda a obra e, para isso, ainda que ligeiramente, um bocadinho, devo me referir àqueles de quem tiver falado antes... ${ }^{24}$

Suvórin, por sua vez, considerou a novela subjetiva e publicitária, ao que Tchékhov lhe respondeu com irritação.

Se Ihe servem café, não o confunda com cerveja. Se the apresento os pensamentos dum professor, não procure neles os pensamentos de Tchékhov, e acredite em mim. Fico imensamente grato. Na novela inteira há apenas um pensamento que eu compartilho, e ele está na cabeça do genro do professor, o trapeceiro Hnecker; é o seguinte: "O velho perdeu o juízo!" Todo o resto é inventado e fabricado... Onde é que você encontrou literatura jornalistica? Será que você dá tanto valor a opiniões de qualquer gênero, que vê somente nelas o centro de gravidade, e não na maneira de expressá-las, nem na origem delas etc.? Então, o Disciple, de Bourget, é também literatura jornalistica? Para mim, como autor, essas opiniões, pela sua essência, não têm nenhum valor. A questâo não está na essência delas, que varia e não é nova. O fundamental está na natureza dessas opiniões, na sua submissão às influências externas etc. É preciso examiná-las como coisas, como sintomas, de modo totalmente objetivo,

${ }^{24}$ A.P.Tchékhov: Cartas para uma poética, 1995, p.151 
procurando não concordar com elas, nem contestá-las. Se eu descrever a dança de São Guido, você não a verá sob a perspectiva dum coreógrafo. Não é? Deve acontecer o mesmo em relação às opiniões. Não tive a menor pretensão de lhe causar espanto com as minhas opiniões surpreendentes acerca de teatro, literatura etc.; eu só quis aproveitar os meus conhecimentos e mostrar o círculo vicioso em que caiu um homem bom e inteligente que, apesar de toda a sua vontade de aceitar de Deus a vida tal com ela é, e de pensar nos outros de modo cristão, querendo ou não, queixa-se e resmunga como escravo, insulta as pessoas, inclusive quando se força a falar bem delas. Ele quer interceder a favor dos estudantes, mas não consegue nada, a não ser hipocrisias e insultos à maneira de Jítiel. Bem, tudo isso é uma longa história... ${ }^{25}$

temas da contemporaneidade, nos contos de Tchékhov, não os houvera até então; da carta vê-se que a "novidade" da novela para o próprio escritor estava não nas "opiniões e reflexões", mas no modo de o professor expressar os seus pensamentos

Bem no início de novembro de 1889, a novela "Uma História Enfadonha" foi publicada no № 11 da revista "Mensageiro do Norte".

Contrariando os temores de Tchékhov, os leitores receberam-na com entusiasmo.

Escreve Plechtchéev já a 5 de Novembro:

"Apresso-me a alegrá-lo, querido Antón Pávlovitch. Ouço, de todos os lados elogios, entusiásticos à sua novela, de pessoas de diferentes opiniões, círculos e campos. Alguns até dizem que ela é o melhor que o Sr. já escreveu. Outros, que a novela deixa uma impressão profunda; terceiros, que é algo inteiramente novo; e, por fim, que é a coisa mais notável do "Mensageiro do Norte" deste ano inteiro... Eu não conseguiria dizer-Ihe quanto isso me é agradável. Eu, devo confessar-lhe, não esperava de modo nenhum que ao "público" essa sua última obra fosse agradar... Ela, parecia-

${ }^{25}$ A.P. TCHÉKHOV: Cartas para uma poética, 1995, p.155 
me, é mais para conhecedores. Eu pensava que a fossem achar tediosa. E imagine só - nem um pouquinho! Achar-lhe-ão defeitos, claro; mas isso não quer dizer nada; que obra não tem defeitos? Mas todos depositam grandes esperanças no seu talento e esperam impacientemente por um seu romance... Vêem na sua novela, não apenas um passo à frente, como também uma viragem para a seriedade e profundidade de conteúdo". ${ }^{26}$

Falam da novela como um "testemunho de maturidade filosófica" (V. Tíkhonov) ${ }^{27}$, uma "coisa inteligente dos diabos" (F. Tchervínskii), como "a sua novela que, dentre todas, tivera o maior êxito" (K. Golóvin ${ }^{28}$.

Liev Tolstói, segundo testemunho de Goldenveiser, durante a leitura dela, "o tempo todo expressava admiração pela inteligência de Tchékhov".

Se os leitores receberam "Uma História Enfadonha" com entusiasmo, dos críticos não se pode dizer o mesmo.

\footnotetext{
${ }^{26}$ A. TCHÉKHOV, Moscou, 1979, p.271

27

p. 674-675.

28 p. 674-675.
} 


\section{Crítica}

De 2002 a 2016, sob a redação de Ígor Sukhikh, saíram três tomos da antologia "A. P. Tchékhov: Pro et Contra", nos quais foram reunidos os principais artigos críticos, dedicados à obra de Tchékhov e publicados nos períodos, propriamente, de 1887 a 1914, 1914 a 1960 e 1960 a 2010.

A antologia é de valor inestimável para todos os estudiosos da obra de Tchékhov. Abre-a um artigo do seu redator, intitulado Современники " "Os que disseram Eh! Os contemporâneos lêem Tchékhov", em que ele analisa as principais correntes da crítica. Conclui-a o artigo "Антон Чехов как зеркало русской критики" ("Antón Tchékhov como espelho da crítica russa"), de A. Stepánov, que analisa os trabalhos mais interessantes à luz dos tratamentos contemporâneos da obra do escritor. ${ }^{29}$

A crítica de tendência realista, antes de mais nada, estabelecera critérios ideológicos para a literatura, como a representação da vida social, e, no entendimento dela, precisamente aos escritores fora dado o direito sagrado e a obrigação sagrada de mostrar as chagas da sociedade, explicando as suas causas aos leitores e opinando acerca delas, de mostrar caminhos e definir ideais, cuja tendência era óbvia: o serviço a algo "supra-pessoal", fosse a Humanidade ou fosse deus. As ideias dos anos de 1860 envelheceram, mas ainda permaneciam dominantes. O principal crítico do período foi N. Mikhailóvskii.

Ao mesmo tempo, porém, abeirava-se o "século de prata" ("серебрянный век"), е a obra de Tchékhov, pelos critérios temporais, inscreve-se bem no início de tal período. Transcorria o desmoronamento das antigas ideias acerca da vida em todas as esferas - política, ciência, religião. Como consequência disso, iniciaram-se buscas dum novo sentido e de novas formas em todos os tipos de arte - pintura, música, teatro, arquitetura, balé e, claro está, literatura. E, naturalmente, também a crítica literária.

O aspecto comum, que se pode notar nela já de saída, é o tratamento da obra tchekhoviana pelo prisma da tendência abraçada pelo crítico,

${ }^{29}$ A.TCHÉKHOV: Pro et Contra, I.Sukhikh, 2002, p.10, p.976. 
fosse ele o democrata N. Mikhailóvskii, lá dos anos sessenta, o simbolista Andriéi Biély, o futurista V. Maiakóvskii ou os filósofos L. Chestov e S. Bulgákov. Quer dizer, o "escapadiço" Tchékhov podia ser examinado de qualquer posição, e, se ele não se inscrevia na ideologia ou corrente do crítico-examinador, tal "falha" era declarada um "defeito" do escritor, uma imaturidade sua, ausência de ideais, falta de ânimo e entusiasmo, indiferença e outros epítetos semelhantes.

\begin{abstract}
"O mundo universal de Tchékhov demonstrou a capacidade de entrar em contacto com quase todas, se não com todas, as doutrinas estéticas do século 20, revelando-se, invariavelmente, maior do que qualquer uma delas". ${ }^{30}$
\end{abstract}

Por si só, isso não é de admirar; contudo, quando lemos os artigos do tempo de Tchékhov, verificamos algo muito interessante: muitas particularidades do seu novo estilo, incompreendidos ou não aceitos pela crítica, foram intuitivamente assinalados já então, bem lá no início, e são considerados, pelos tchekhovistas contemporâneos como os elementos basilares da estilística do escritor.

\begin{abstract}
"A incompreensão do autor-inovador pela crítica contemporânea a ele pode manifestar-se de duas maneiras: ou atribuem-se-lhe qualidades que ele não tem, ou a sua inovação é considerada como defeito. O segundo caso é preferível para os escritores "fortes", e, nesse sentido, Tchékhov teve sorte: à voz do "contra" imediatamente deu o tom um leitor muito refinado, que notara as particularidades da poética, que depois as vozes do "A favor" ignorariam. (Stepánov) $)^{31}$
\end{abstract}

Porquanto a novela "Uma História Enfadonha" foi escrita na forma de apontamentos em primeira pessoa e contém grande quantidade de

\footnotetext{
${ }^{30}$ A.TCHÉKHOV: Pro et Contra, 2002, p.29.

${ }^{31}$ A.TCHÉKHOV: 
reflexões acerca dos mais diversos temas, inclusive o duma "ideia geral" (общая идея), logo após a publicação da revista com a coletânea "Gente Carrancuda", e em seguida dela própria em livro, a crítica quase unanimemente, tendo reconhecido o indubitável talento do jovem escritor, resolveu a questão da identidade do autor e da personagem, atribuindo os pensamentos e dúvidas do velho médico ao próprio Tchékhov. O problema filosófico da existência duma "ideia geral" na vida duma pessoa é reconhecido por todos como central. E a novela acabou por ser muito mais um exemplo adequado para a análise da concepção de mundo do escritor (mais exatamente, na perspectiva da crítica contemporânea a Tchékhov, denunciar a falta de tal concepção) do que objeto de estudo em si, como obra literária. Na maioria dos artigos, cita-se o último diálogo da personagem com Kátia ou as reflexões de Nikolai Stepánovitch acerca de não ter uma "ideia geral", e a isso segue-se a inevitável conclusão de que o próprio escritor também não tinha uma. Assim, aflige-se o crítico P. Piértsev com que a impressão da força do talento e do colorido traz, contudo, a estranha sensação de que "falta algo" (P. Pertsev 183 ).

Praticamente em todos os artigos, encontra-se uma mesma ideia: não há resposta à pergunta acerca do que é a ideia geral, o deus da pessoa viva. Tchékhov detém-se no limiar da coisa principal e não o transpõe, "e fica o leitor um tanto perplexo, diante de portas trancadas" (Albov). ${ }^{32}$

E não fora à toa que Tchékhov temia ironias quanto ao título da novela. L. Liátskii chama ao diálogo de Tchékhov com o leitor "uma história tediosa, muito tediosa". ${ }^{33}$

A crítica não deixou de atentar também para o título da coletânea "Gente carrancuda", e as opiniões acerca da sua correspondência ao estado de espírito principal do ciclo são as mais diversas. OvsiánnikoKulikóvskii considera que Tchékhov estuda a psicologia da "carrancudez"

\footnotetext{
${ }^{32}$ A.TCHÉKHOV: Pro et Contra, 2002, p.382.

p..467. A tradução mais correta do título da obra seria "Uma história tediosa" (não "enfadonha"), segundo o nosso orientador e os membros da minha banca do Exame de Qualificação.
} 
(Ovsianiko-Kulikovski) ${ }^{34}$, ao passo que N. Mikhailóvski é de opinião totalmente oposta, acentuando que o título não corresponde nem um pouquinho ao conteúdo da obra e fora escolhido aleatoriamente (Н.Михайловский ).

Para além da falta de concepção de mundo, ideais e uma ideia geral, as declarações irritadas do professor de sessenta e dois anos contra praticamente todos os fatos da vida contemporânea a ele, tanto da vida

cotidiana quanto da arte, teatro, literatura e a sua insatisfação com os estudantes e a universidade foram quase unanimemente atribuídas ao jovem autor. Convergem os críticos também na consolidação do chavão acerca do "pessimismo" de Tchékhov (Disterlo, Kign, Protopópov, Govorukha-Otrok e outros).

A caracterização da personagem principal de "Uma História Enfadonha" resumia-se, fundamentalmente, a quanto ela era típica da realidade dos dois últimos decênios daquele século e quão típica era a própria realidade representada por Tchékhov. Tendo acusado o próprio escritor e as suas personagens de não possuírem ideais, a maioria dos críticos, seguindo Mikhailóvski, fazem a mesma acusação à geração "apática", "desprovida de ideias" e desiludida dos anos 1880 da época da estagnação cultural e social , e, a partir daí, Tchékhov torna-se um porta-voz dessas novas pessoas "supérfluas". Da posição vantajosa dos nossos contemporâneos de hoje, podemos notar a quantidade de chavões usados para qualificar essa pobre geração, muitos representantes da qual logo depois se tornariam personagens do "século de prata" ou revolucionários e terminariam a vida tragicamente na Rússia ou no exterior e provariam sofrimentos tais, que para muitos deles os "tormentos" das personagens tchekhovianas seriam incompreensíveis, insignificantes, obscuros e até irritantes. A mudança de épocas ocorrera com tanta rapidez, que a nós, às vezes, parece que da geração dos anos 1880-1900 não restara ninguém por volta da revolução russa, embora da publicação de "Uma História

\footnotetext{
${ }^{34}$ A.TCHÉKHOV: Pro et Contra, 2002, p.488.
} 
Enfadonha" até à salva de tiros do cruzador "Aurora" se houvessem passado apenas vinte e oito anos, e muitos parentes e conhecidos de Tchékhov, por exemplo, a sua irmã Maria Pávlovna, a sua esposa, Olga Leonárdovna Knipper, o seu amigo Ivan Búnin, Dmítrii Merejkóvskii e Zinaída Híppius e outros, isto é, os que conseguiram sobreviver, viveram até à metade do século vinte.

O fato de que o fim do século 20 e o começo do 21 , não somente na Rússia, seriam chamados de "o tempo de Tchékhov", ninguém, certamente, poderia ter suposto. É difícil acusar os que escreveram acerca do escritor de falta de clarividência e incapacidade de prever a sua incomparável influência na literatura mundial futura. Nos anos 1890, o seu principal "mérito", segundo a opinião geral, era a representação do estado de espírito da sua geração.

São muito raras as referências ao estilo, à composição e às particularidades artísticas da novela, bem como ao retrato psicológico da personagem, embora os críticos notassem a contenção e o laconismo da escrita tchekhoviana (Ovsianniko-Kulikóvski ${ }^{35}$, Neviédomski ${ }^{36}$ ).

Levantou-se também a questão das fontes da obra, e foi muito lembrada "A Morte de Iván Ilitch", de Tolstói.

"se não tivesse havido "A Morte de Ivan Ilitch", não teria havido nem "Uma História Enfadonha", "Ivánov", nem outras grandes obras de Tchékhov" (Chestóv). ${ }^{37}$

Também houve, no entanto, opinões opostas; I. Búnin e Kign expressaram dúvidas acerca da forte influência de Tolstói em Tchékhov.

I.Sukhikh considera que, ao fim e ao cabo, Tchékhov não encontrou o crítico ideal ou, pelo menos, o seu crítico entre os contemporâneos. ${ }^{38}$

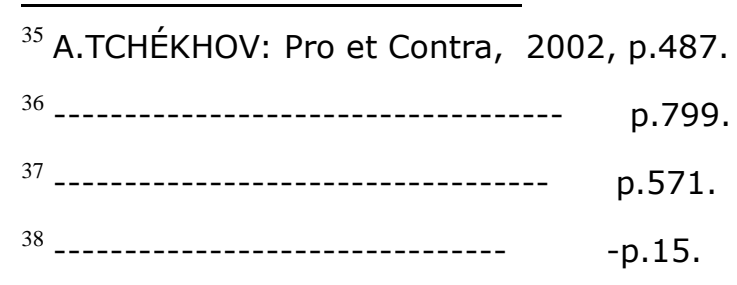


Citemos o testemunho de Búnin, que está no seu livro de reminiscências "Acerca de Tchékhov":

"Ele trabalhou quase 25 anos, e quantos reproches triviais e rudes ouviu ele nesse tempo todo!

- Leu, Antón Pávlovitch? - dizia-Ihe alguém que vira algures um artigo a respeito dele.

Ele apenas olhava de esguelha, por cima do pincenê, e, de pescoço esticado, respondia com a sua voz de baixo:

- Ora, muito obrigado! Escrevem mil páginas acerca de alguma pessoa e acrescentam em baixo: "e existe ainda o escritor Tchékhov: um choramingas..." E que choramingas sou eu? Que "pessoa carrancuda" sou eu, que "sangue frio" sou eu, como me chamam os críticos? Que "pessimista" sou eu? Das minhas obras, a minha preferida é o conto "Estudante"... E que palavra asquerosa: "pessimista"... Não, os críticos são piores do que os atores. Como sabe, em matéria de desenvolvimento, os atores estão setenta anos atrás do povo russo.

$E$, às vezes, acrescentava:

- Quando o xingarem por aí, meu caro senhor, lembre-se mais vezes de nós, pecadores; os críticos batem em nós, como no seminário, pela menor falta. Um crítico até me profetizou que eu morrerei na miséria: ele achava-me um rapaz expulso da escola por bebedeira" (I. Búnin). ${ }^{39}$

Contudo, havia também artigos merecedores de atenção especial. Sobretudo, "Acerca de pais e filhos e do Sr. Tchékhov", de N. Mikhailóvski. Era precisamente este em primeiro lugar que A. Stepánov tinha em mente, ao falar dum "crítico suficientemente sensível" . O referido trabalho de $\mathrm{N}$. Mikhailóvskii teve grande repercussão e foi objeto de aprovação, discussões, citações e discordâncias.

Ele começa com uma ironia acerca duma acalorada discussão da publicística dos anos de 1880 acerca de "pais" e "filhos", isto é, a geração dos anos sessenta, com as suas ideias sociais, "ideais", temas e aqueles

\footnotetext{
${ }^{39}$ Putechestvie k Tchékhovu, Moscou, 1996 p.449.
} 
que vivem a realidade e a aceitam, negando quaisquer ideias (faz-se a divisão não pelo critério etário, mas exclusivamente ideológico). Mikhailovski não emprega a palavra "niilismo", embora, sem dúvida, fale precisamente disso. Os que a si chamam "filhos", são-Ihe desagradáveis, desprovidos de interesse e ridículos.

Ao passar à critica da coletânea "Gente Carrancuda", ele assinala que Tchékhov era, até àquele momento, o único literato talentoso da sua geração literária, mas, por causa da sua falta de ideologia, não era capaz de atingir o alto nível dos clássicos da literatura russa:

"E eu não conheço espetáculo mais triste do que esse talento desperdiçado à toa" (Mikhailóvski). ${ }^{40}$

Mikhailóvski encanta-se com a capacidade de Tchékhov de animar a natureza e espiritualizar tudo o que é inanimado, mas, a par disso, observa que para ele não é importante acerca de que escrever, como se

"passeasse em frente à vida e, nesse passeio, arrancasse algo cá, outra coisa acolá" (Mikhailóvski). ${ }^{41}$

e põe-se a escrevinhar com indiferença, com "sangue frio". O crítico também nota a escolha aleatória dos temas, a falta de hierarquia no sistema artístico do escritor, os promenores fortuitos, sem relação com o enredo nem com as características das personagens, a falta de um claro elo lógico, causas e efeitos e explicações - enfim, tudo o que hoje é reconhecido como a natureza ímpar do estilo tchekhoviano.

$\mathrm{Na}$ ótica de Mikhailóvski, tais traços revelam tão-somente a indiferença e negligência do jovem e talentoso escritor, a sua frieza emocional. Ele vai lendo os contos da coletânea e parece começar "Uma

\footnotetext{
${ }^{40}$ A.TCHÉKHOV: Pro et Contra, 2002, p.84. 41 
História Enfadonha" com decepção, mas aí a sua opinião muda radicalmente, e ele caracteriza a novela como "a melhor coisa e a mais valiosa de tudo o que o Sr. Tchékhov escreveu até hoje". A falta de um ideal ao professor, para Mikhailóvski, é um testemunho indubitável da falta de um ideal também ao escritor, mas precisamente no anseio por um ideal, por "uma ideia geral", o crítico enxerga algo que os hiilistas de então não tinham; foi precisamente tal anseio que lhe suscitou uma impressão tão forte da novela, e era nessa direção que ele via a saída para o talento "condenado a morrer". A figura de Tchékhov como "poeta do anseio por um ideal" e "cantor do crepúsculo" foi levada adiante por muitas outras vozes.

A tendência principal e a essência do escritor, para o filósofo Chestóv, era que Tchékhov, na sua criação, matava as esperanças e ideais humanos com todos os meios possíveis:

"E o próprio Tchékhov empalidecia, murchava e perecia diante dos nossos olhos - nele não perecia apenas a sua arte admirável de só com um toque, até um sopro, um olhar, de matar tudo aquilo de que as pessoas vivem e se orgulham... Nas mãos de Tchékhov, tudo morria (Chestóv).

É necessário assinalar que tal caracterização de Tchékhov foi feita com intenção positiva por Chestóv, um filósofo, para quem o mundo é irracional e quaisquer tentativas de sua explicação e quaisquer respostas a questões globais da Humanidade não passam de engano.

E, no exemplo de "Uma História Enfadonha", Chestóv aponta mais uma caraterística importante da obra de Tchékhov: aversão ao pathos e às palavras elevadas, inaceitação da reserva de ideias gerais e concepções de mundo, acumulada pela literatura, e aversão a ela e recusa a todas as consolações metafísicas e positivas possíveis. Ele achava que Tchékhov

"emancipa-se completamente de todo o tipo de ideias e concepções de mundo e até perde a ideia da relação entre todos 
os acontecimentos da vida", e apresenta isso como o traço mais significante e original da sua obra (Shestov). ${ }^{42}$

A morte do escritor suscitou uma nova vaga de artigos, e durante ainda muitos anos acerca dele escreveram críticos (V,Vorovski, Ju.Ajkhenvald, M.Nevedomski, A.Izmailov, A.Dolinin), escritores (A.Belyi, K.Tchukovskii, V.Majakovskii), filósofos (S.Bulgakov, L.Chestov, D.Filosofov, V.Rozanov), e até médicos psiquiatras (M.Nikitin, N.Shapir)), para não falarmos das inúmeras reminiscências de contemporâneos. Mas já

em Agosto de 1914, o tempo de Tchékhov acabara, extinguira-se, qual corda rompida, o século dezenove, cuja duração fora além do calendário. No "Verdadeiro Século Vinte", durante algum tempo, não se estava para discussões literárias nem se queria saber da própria literatura. Quando, nos anos vinte, de novo se lembraram de Tchékhov, tudo estava mudado: o mundo, o país, as pessoas, as questões, as respostas e, parece, até os próprios textos de Tchékhov" (Sukhih). ${ }^{43}$

O "Século de Prata", com raras exceções (A. Biely, A. Blok, V. Maiakóvski), não aceitou Tchékhov. O que se escreveu acerca dele tem pouco valor e é, via de regra, de caráter negativo (A. Akhmatova, Z. Gippius e outros): era outro tempo, não tchekhoviano. Os formalistas ignoram-no completamente. E, apesar de em 1928 ter aparecido o livro "O Naturalismo de Tchékhov", de Leonid Grossman, pode dizer-se que, no início da era soviética, o interesse pela obra de Tchékhov continuou a diminuir até que entre os críticos do campo do realismo socialista, entre os V. Ermílov, alguém não descobrisse um novo Tchékhov, "soviético", que desmascarava furiosamente o espírito pequeno-burguês e se erguia em defesa de todos os "russos simples e trabalhadores" oprimidos, no anseio

\footnotetext{
${ }^{42}$ A.TCHÉKHOV: Pro et Contra, 2002, p.571. 43 
de responder à pergunta "que fazer?".

"Num tempo difícil, o povo buscador da verdade criou e educou o seu grande escritor, Antón Pávlovitch Tchékhov, e encaminhou-o a difíceis buscas". ${ }^{44}$

E já dessa nova plataforma ideológica, na novela "Uma História Enfadonha", examinam-se temas já tratados pela crítica contemporânea a ele. Porém, o defeito torna-se qualidade e, à diferença do Tchékhov anterior, o Tchékhov soviético passa a ter uma firme posição ideológica e responde às questões do seu tempo "inanimado", de que era intérprete a personagem principal da novela. Assim, os sofrimentos de Nikolai Stepánovitch explicam-se pela falta dum objetivo único na sociedade:

... tudo isso é inevitável numa sociedade dividida em partezinhas separadas, numa sociedade não inspirada por um objetivo único, por uma grande ideia geral (...). Tchékhov não queria ficar na situação da personagem, que à pergunta 'que fazer?' respondia com um honesto mas sincero 'não sei'. E Tchékhov sentia-se obrigado a responder a essa pergunta". ${ }^{45}$

A situação começou gradualmente a mudar na metade do século vinte. Os pesquisadores, para além de grande atenção à biografia do escritor, retomam a questão da continuidade das tradições da literatura russa clássica em Tchékhov, sem deixarem de assinalar a originalidade do seu estilo. Por exemplo, V. Kulechov, M. Gromov e S. Nikolaeva estudam a recepção de figuras e motivos de Dostoiévski em obras de Tchékhov; em trabalhos de G. Biályi, M. Semanova e J. Jalgasbaeva, investiga-se a tradição turgueneviana; V. Lakchin e A. Kuzitcheva analisam a influência de L. Tolstói na formação do escritor.

\footnotetext{
${ }^{44}$ Disponivel em:http://az.lib.ru/c/chehow_a_p/text_0490.shtml

${ }^{45}$ Disponivel em http://az.lib.ru/c/chehow_a_p/text_0490.shtml
} 
A partir dos anos oitenta, na União Soviética, aparecem significativas monografias acerca tanto dos vários aspectos do sistema artístico de Tchékhov, quanto de alguns contos, novelas e peças (A. Tchudakov, V.Kataev, V.Lincov, I.Sukhikh). A. Tchudakov em «Поэтика Чехова» (А poética de Tchekhov), de 1971, foi um dos primeiros que apresentaram métodos exatos de descrição do sistema narrativo do escritor. Com base numa acurada análise de textos e aproveitamento de extenso material, a autora estabelece as características comuns a todos os níveis do referido sistema (narrativas de vários períodos da obra do escritor, enredo e esfera de ideias), dedica atenção especial ao mundo material e introduz o conceito de "pormenor fortuito".O livro Проза Чехова: проблемы интерпретации (A prosa de Tchékhov, 1979), de V. Katáev, é dedicado a questões polémicas da interpretação duma série de obras do escritor e a diversos procedimentos de estudo aplicáveis à análise da sua prosa. 0 trabalho contém a interpretação de alguns contos, novelas e peças e enfatiza a peculiaridade da mentalidade das personagens tchekhovianas, a qual "os leva a um impasse", sendo causa de desconcerto e padecimentos. Na qualidade de princípio artístico original do escritor Katáev aponta "a individualização de cada acontecimento em particular".Na monografia de Ígor Sukhikh, "Проблемы поэтики Чехова" (Problemas da poética de Tchékhov), de 1987, também se apresenta um estudo integral do mundo artístico do escritor e do seu lugar no contexto da literatura russa do século XIX. Analisam-se minuciosamente o primeiro drama e contos da primeira fase, as novelas "A estepe" e "O monge negro", o livro A ilha de Sacalina e o conto "A casa de mezanino". O autor debruça-se sobre a polémica questão da filosofia artística e é quem primeiro a estudar o problema do cronótopo tchekhoviano.

Em outros países, como Alemanha e Estados Unidos, nesse período, o seu legado tornou-se objeto de estudo para a corrente psicoanalítica nos estudos literários, a qual dedicava grande atenção à concepção dos arquétipos mitológicos do inconsciente coletivo, elaborada por K. Jung (S.Senderóvitch). 
Uma nova página nos estudos tchekhovianos veio a ser a série "Tchekhoviana", de trabalhos científicos, publicada pelo Conselho Tchekhoviano de História da Cultura Mundial, da Academia das Ciências da Rússia. Ela reúne artigos e ensaios de estudiosos contemporâneos, que revelam um aspecto e outro da obra do escritor. Atualmente, saem regularmente as coletâneas «Чеховский вестник» (O Mensageiro Tchekhoviano) е «Молодые исследователи Чехова» (Jovens Pesquisadores de Tchékhov), nas quais se publicam trabalhos de jovens tchekhovistas.

Começaram a ser objetos de estudo o cronótopo de Tchékhov, a dinâmica dos motivos, a simbologia, a interstextualidade e a filosofia do escritor, mas tais temas permanecem pouco estudados e à luz das novas pesquisas demandam uma elaboração mais acurada.

Podemos concluir que a novela "Uma História Enfadonha" nunca foi estudada na totalidade da sua estilística, composição, símbolos, pormenores, inclusive os "fortuitos", e ritmos. Quase não se escreveu acerca das suas personagens e do seu papel nela, com as exceções de Nikolai Stepánovitch e Kátia (esta, esquematicamente, com as palavras daquele, sem consideração do subtexto tchekhoviano). Tampouco foram estudados os temas das recordações, infância, música, animais, reminiscências e citações, bem como o tempo e o espaço na sua relação com todos os elementos literários supracitados.

Tentaremos preencher tais lacunas, no nosso trabalho. Cumpre assinalar que representa certa dificuldade a tarefa de, a par do texto original, analisarmos também a sua tradução em português, na qual, infelizmente, apesar do brilhante trabalho de Bóris Schnaiderman, muito se perdeu, enfraquecendo, com isso, a percepção do subtexto da obra. 


\section{Elementos da composição da novela}

\subsection{Conceito geral de composição duma obra literária}

$\mathrm{O}$ artista deve julgar apenas aquilo que entende, seu círculo é tão limitado quanto o de qualquer outro especialista -- é o que repito e no que insisto sempre. Que em sua esfera não haja questões, mas apenas respostas, só quem nunca escreveu e não lidou com imagens é capaz de dizer. O artista observa, escolhe, adivinha, arranja: essas operações já pressupõem, em sua origem, um problema. Se o problema não tiver sido colocado desde o início, não haverá nada por adivinhar nem por escolher. A fim de ser mais breve, terminarei através de psiquiatria: se o problema e a intenção forem negados no ato criativo, será então necessário admitir que o artista cria sem premeditar e sem um propósito, sob a influência da emoção; por isso, se um autor se vangloriasse diante de mim de haver escrito uma narrativa sem intenção premeditada, apenas por inspiração, eu o chamaria de louco. (103) ${ }^{46}$

O modo de construção e organização do texto literário e a interligação entre os seus elementos, que provêem a sua unidade e inteireza, isto é, um material selecionado e disposto de determinada maneira para a obtenção do máximo efeito emocional e semântico sobre o leitor em conformidade com a ideia do autor, eis o que é a composição da obra literária.

Esse é um conceito complexo e multiplanar. Daí a grande quantidade de modos de tratá-lo e a multivariedade de concepções que incluem a diferença das definições do próprio conceito. Apesar disso, reconhece-se como base à revelação dos meios, que tornam possível o diálogo entre o

\footnotetext{
46 TCHÉKHOV, Anton. "O beijo" e outras histórias. São Paulo, 2010, 3a ed. Tradução de Boris Schnaiderman

Aqui e doravante, os números entre parênteses indicam as páginas no texto da novela.

Utilizámos, no nosso trabalho, a tradução de Boris Schnaiderman.
} 
autor e o leitor (M.Bakhtín, V.Vinogradov, L.Vygódski, G.Gukovski, V.Zhirmunski ,J.Lótman, B. Uspénski, V. Chklovski, L. Scherba e outros).

Da composição de obras de Tchékhov trataram diretamente L. Lélis e E. Polótskaia, entre outros.

Em vista da brevidade e concisão e, simultaneamente, saturação semântica das obras de Tchékhov, o estudo dos seus procedimentos composicionais afigura-se especialmente complexo e interessante.

No seu trabalho, Tchékhov contava com um leitor talentoso e dotado de boa intuição, capaz, ademais, de captar matizes, os mínimos pormenores, o significado oculto no subtexto e expresso por sinais linguísticos, ou seja, com uma pessoa que, à leitura, entrasse em diálogo com o autor, individualizando o material recebido com a sua própria experiência e a sua própria e inconfundível (exclusiva) personalidade.

Quando eu escrevo, confio inteiramente no leitor, supondo que ele próprio acrescentará os elementos subjetivos que faltem ao conto. ${ }^{47}$

L. Kaida, no livro Стилистика текста: от теории композиции декодированию (Estilística do texto: da teoria da composição à decodificação $)^{48}$, que constitui o mais minucioso estudo dos problemas contemporâneos da composição, afirma que o leitor é capaz de ler o texto com uma profundidade inimaginável pelo escritor e enxergar o que este quisera dizer e, às vezes, até o dito inconscientemente. E tal não por força dum "feliz lampejo", senão duma habilidade profissional de juntar todas as pontas soltas e contextos num todo único.

Na análise da composição de "Uma história enfadonha", nós nos ateremos aos seus seguintes elementos:

- Título e subtítulo;

\footnotetext{
${ }^{47}$ A.TCHÉKHOV, Moscou, 1977, p.174.

${ }^{48}$ L.KAJDA, Nauka, Flinta, 2005.
} 
- Lances do enredo;

- O início e o final da novela;

- As personagens;

-Elementos extra-enredo ( temas, motivos, pormenores);

- Ritmo;

-Tempo e espaço.

Atenção especial será dada aos procedimentos de repetição, variação e contraposição (antíteses), encontrados no texto.

O objetivo do nosso trabalho é mostrar como todos os elementos supralistados da composição literária, funcionando em prol da ideia do autor, formam o subtexto da novela, agindo tanto na consciência quanto no subconsciente do leitor.

Aquilo em que sem dúvida se pode buscar a posição do autor, principalmente nas obras escritas em nome da pessoa da personagem, são o título, o subtítulo e a correlação entre os diversos elementos artísticos independentes e a sua "montagem" por uma determinada figura, dada pelo autor, isto é, a composição.

\subsection{Título, subtítulo}

O primeiro título da novela foi "O meu nome e eu". Antes de mais nada, observemos que, como pode ver-se, ele é dado pela própria personagem, à diferença do subtítulo "Dos apontamentos duma pessoa velha", dado pelo autor. O mesmo pode encontrar-se em outras obras de Tchékhov, também escritas na pessoa da personagem, por exemplo, "Minha vida" (Conto dum provinciano). Em "O meu nome e eu", já de saída se indica o tema principal: uma pessoa e o seu famoso nome, separados um do outro, tanto na vida cotidiana quanto na percepção das pessoas, e na História. Provavelmente, foi essa a ideia básica da ideia original da novela (ou, naquele momento, do conto). Premissa para isso foram, sem dúvida, as reflexões também acerca da própria fama sobre o fundo da vida cotidiana, mas um impulso especial para a análise desse tema foi a morte do insigne viajante N. M. Prjeválskii, ocorrida em 20 de 
outubro de 1888. Seis dias depois, no jornal "Novo Tempo" (Новое время), saiu um obituário sem título nem assinatura, de autoria de Tchékhov. O texto estava vazado em um estilo insólito para os leitores do escritor - exaltado, quase patético, em relação às "pessoas de façanhas", e invectivador em relação à sociedade de então. Esse deve ter sido o único texto do gênero. Para nós ele é importante não apenas sob o aspecto do surgimento da ideia de representar uma pessoa famosa, uma pessoa que se tornara lenda, o que se subentende sob o conceito de "nome" na vida familiar habitual, como também por algumas outras intersecções com a novela estudada por nós.

"No nosso grande tempo, quando das sociedades europeias se apoderaram a preguiça, o tédio da vida e a descrença, quando, em toda a parte, em uma estranha mútua combinação, reinam o desamor à vida e o medo à morte, quando até as melhores pessoas ficam de braços cruzados, justificando a sua preguiça e a sua depravação com a falta de certo objetivo na vida, os abnegados capazes de proezas são necessários como o Sol". ${ }^{49}$

Tais palavras podem ser diretamente atribuídas tanto à personagem principal quanto a Kátia, o que confirmam cartas de Tchékhov do tempo da escrita da novela. Nesta há "tédio da vida", "preguiça", "falta de objetivos". Também aparece a palavra "Sol" em contexto próximo: "...

...daqui a uns três meses ele, representado por letras douradas na lápide do túmulo, brilhará como o próprio Sol...

$\mathrm{Na}$ perspectiva da sociedade e do processo histórico, Nikolai Stepánovitch, cientista famoso no mundo todo, compreende que logo permanecerá na lembrança das pessoas apenas como um nome, herói, lenda, mas por ora ele, que escreve apontamentos, é simplesmente um

${ }^{49}$ A.TCHÉKHOV, Moscou, 1979, p.236. 
moribundo, assustado com a morte próxima, uma pessoa desconcertada, que vive no seu mundinho exíguo e perdeu a ligação espiritual com as pessoas mais próximas e com a própria vida. Ele próprio tenta entender tal contradição.

O tema da antítese "meu nome e eu" atravessa a novela inteira; "Uma história enfadonha" começa, propriamente, com a apresentação do "nome" e, só depois, da pessoa, isto é, o leitor nota a separação dos dois já nas primeiras palavras da novela. E o último capítulo está recheado de reminiscências da personagem acerca desse tema.

Aparentemente, o título "O meu nome e eu" poderia refletir em completa medida o tema principal da obra. É possível supor que, com a conservação do tema "o meu nome e eu", este deixa, contudo, de ser o principal.

No título "Uma história enfadonha" e no subtítulo "Dos apontamentos de uma pessoa velha", cada palavra é de significado importante. O fato de que os lexemas "скука/tédio" е "скучный/tedioso" estejam entre os mais frequentemente usados por Tchékhov tanto nas suas obras quanto na sua epistolagrafia (como já o assinalámos no capítulo "Históra da escrita da novela"), foi notado há já muito tempo pelos leitores e pelos estudiosos.

No dicionário de Uchakov, «скука» ("tédio") é definido como "ânsia, angústia, estado penoso de alma gerado pela ociosidade, falta de ocupações ou falta de interesse por tudo à volta". ${ }^{50}$

No de Dal', "sentimento penoso gerado por um estado de espírito rotineiro, ocioso e inativo". ${ }^{51}$ Porém, nas obras de Tchékhov, a palavra "скука" (tédio) constitui um conceito muito mais complexo e polissêmico em comparação com o seu significado corrente e possui muitos matizes, uma simbólica e sentidos complementares.

Encontra-se a palavra "скука" em quase todas as obras do escritor,

\footnotetext{
${ }^{50}$ Disponivel em: (http://tolkslovar.ru/s6929.html).

${ }^{51}$ Disponivel em: (http://tolkslovar.ru/s6929.html)
} 
principalmente nas da metade dos anos $80 \mathrm{em}$ diante. Aparece inúmeras vezes até nos títulos ("Скука жизни"/ Tédio da vida). E, da mesma forma como outros símbolos, passa duma obra a outra, ecoando o que encontrara antes e aumentando a sua carga semântica. O tédio é um penoso estado de alma por perda da compreensão das ligações da vida concreta com a marcha mundial da vida, com a marcha do tempo e da História, e por perda da compreensão da ligação com a natureza, com os seus ciclos de nascimento e morte, isto é, com tudo o que existe para além do homem, mas sem o que a vida de cada indivíduo concreto é simplesmente impossível. O homem tem a sensação da sua independência do tempo fugidio e a impossibilidade de detê-lo, mas não vê a si no fluxo natural, resistindo a este desamparadamente e em vão. É daí que vem o mais penoso, lancinante e doentio estado de espírito, o tédio tchekhoviano.

E, porquanto, para Tchékhov, existem conceitos irracionais, não passíveis de explicação, então a personagem, que tenta restabelecer as ligações com a ajuda de reflexões lógicas, sempre é vencida. Os capazes de perceber a vida intuitivamente, pelas sensações, dissolvendo-se naturalmente nela, na natureza e nos cheiros e cores desta, na mudança das estações e no movimento do tempo, esses já existem no fluxo geral da natureza com os mesmos direitos de cada elemento dela e não estão sujeitos a "tédio", e deles não se exige uma "idéia geral'. Assim são, no mundo de Tchékhov, os animais, as crianças e algumas personagens, como o de "O Duelo" e a própria personagem principal de "Uma história Enfadonha" até a certo ponto da sua vida.

Assinalemos que, na obra de Tchékhov, a Música, pela sua base simbólica, é muito próxima dos conceitos de natureza e vida e, apesar de ser criada por pessoas, é percebida como um fenómeno natural incompreensível, distante e, principalmente, reconstituidor daquela mesma ligação perdida. Sob esse prisma, a palavra "história", no título, possui duplo sentido, como "História" no seu sentido global, como transcurso do tempo, e como "história" duma personalidade concreta e a 
interligação das duas.

Passando ao subtítulo da novela estudada ("Из записок старого человека"/ (Dos apontamentos duma pessoa velha), sublinhamos mais uma vez que ele é o único texto direto do autor, daí a sua importância para nós. Dá-se imediatamente uma definição do género da obra apontamentos. Antes de mais nada, atentemos para a última palavra daquele: "человек" (pessoa). À primeira vista, pode parecer que ela, à diferença de "provinciano" "professor catedrático" etc., não possui nenhuma carga semântica nem dá nenhuma informação complementar acerca da personagem, uma vez que apontamentos só podem ser escritos por uma pessoa. Por que não, então, "из записок старого профессора/ apontamentos de um velho professor catedrático"? Precisamente porque, a nosso ver, "pessoa", última palavra do subtítulo, ecoa a última do título e a antítese surgida, história-pessoa (do que já falámos no parágrafo anterior), possui carga semântica muito maior do que a caracterização da personagem e define logo a ideia principal da novela.

Uma caracterização da personagem, no entanto, está presente na palavra "velho". E, de novo, pode suscitar-se a perplexidade: por que, diante de todas as possibilidades, acha o autor de dizer a sua palavra direta acerca da personagem e escolhe não "famoso", não "doente", até nem "moribundo" e nenhuma outra, mas precisamente a definição "velho". Parece-nos que a escolha de "velho", em comparação com as outras palavras, foi muito mais determinada pela associação, que surge, com a vida vivida, ou seja, de novo com o conceito de tempo.

E, finalmente, a enigmática preposição "de". Parece haver um nítido começo clássico e um nítido término. No entanto, ao empregar tal preposição, o autor sublinha que os apontamentos do professor ou haviam começado antes ou eles têm uma continuação desconhecida do leitor. Por que utilizou Tchékhov tal procedimento?

Na nossa opinião, em primeiro lugar, o autor, com isso, delimita os apontamentos da personagem e a sua novela e, em segundo, assinala, mais uma vez, que aqueles existem não como um texto acabado e solto; 
- leitor não consegue saber ao certo quando começaram e quando terminarão; esses apontamentos existem no fluxo geral e infinito da vida. A preposição "de" comunica tal sensação, apesar de que o leitor logo virá a saber que resta pouco tempo de vida à personagem.

Assim, podemos concluir que, no título e no subtítulo de "Uma história enfadonha", Tchékhov dita logo o tema principal da novela - a vida final duma determinada pessoa no fluxo geral e infinito do tempo, na história geral, e o trágico estado de espírito decorrente disso.

Muitos estudiosos, inclusive contemporâneos de Tchékhov, assinalaram que as suas obras não apresentam o início e o fim tradicionais, como se fossem histórias cuidadosamente recortadas do fluxo geral da vida, o qual, em resultado, se torna a principal personagem, ainda que possa parecer apenas tela de fundo para os acontecimentos e diálogos. O que acontece às pessoas é somente um episódio no tempo infinito ( $A$. Tchudakov). $E$, até quando o conto ou peça acaba com a morte da personagem ("Ivánov", "A gaivota"), algum conflito psicológico ("Tio Vánia") ou algum acontecimento ("O jardim de cerejeiras"), cria-se a impressão de que a vida continua e nada mudou substancialmente.

À primeira vista, "Uma história enfadonha" foge a tal grupo, já que nela, aparentemente, se têm o início e o fim tradicionais da literatura anterior a Tchékhov: a apresentação da personagem, com o seu retrato, e a despedida das personagens principais, respectivamente. No entanto, a realidade é outra.

Desde as primeiras linhas, o catedrático separa a si próprio, homem doente e envelhecido, do seu nome excelso e conhecido no mundo inteiro, e é precisamente a apresentação desse nome o ponto de partida da novela.

No decurso de alguns meses, o moribundo professor de Medicina, ciente da proximidade da morte, escreve apontamentos para si, tentando compreender os pensamentos e sentimentos novos para ele, fazer um balanço da vida vivida e uma avaliação dos parentes e conhecidos, fazendo, de passagem, considerações acerca da sociedade, do teatro e da 
literatura contemporâneos a ele, recordando o passado etc. A sua confissão é, frequentemente, contraditória, ora duma imperturbabilidade que beira com a aridez da Medicina, ora repleta de dúvidas (em carta a Suvórin, Tchékhov chama-Ihes "tergiversações") e emoções. Toda a sua vida fora construída de modo bem pensado e correto; realizara-se o sonho da sua juventude, e ele, cientista de talento, perdidamente apaixonado pela Ciência, pedagogo magnífico, que atingira os píncaros do êxito na sua atividade, homem dum casamento feliz e pai de filhos, relacionado com muitas personalidades eminentes do seu tempo e, para além do mais, pessoa duma atitude sempre tranquila e condescendente para com os defeitos das pessoas comuns, ele, um médico, sabedor do que é a morte, parecia disposto a recebê-la com tranquilidade e coragem ou, pelas suas próprias palavras, "não estragar o final com a sua composição talentosamente feita", como ele define a sua vida vivida, de repente começa a vê-la sob uma luz extremamente negativa, e tudo e todos nela irritam-no. Algo se passa não do modo como deveria, rompem-se as ligações, vai-se o controlo sobre os sentimentos e as ideias; a esposa e a filha parecem pessoas estranhas, os colegas e os alunos parecem-lhe medíocres, e Kátia, a sua querida pupila, parece-Ihe estar a malbaratar a vida; o trabalho, em lugar do antigo arrebatamento, suscita-Ihe um sentimento de desespero e vergonha, e, no conjunto, a vida apresenta-seIhe desprovida de sentido. Nikolai Stepánovitch tenta compreender as causas do que está a acontecer, e de fugir ao "circulo vicioso" em que caíra. As suas tentativas de explicação não Ihe satisfazem; algo escapaIhe, suscitando-lhe novos ataques de medo e desespero, e ele, devastado, em estado de apatia, forçando-se a voltar àquilo em que vinha pensando nos meses anteriores, não chega a concluir pela falta, à sua vida, de algum elo de ligação, a que dá o nome de "ideia geral"; no final, à despedida com Kátia, supõe que a causa dos sofrimentos dela seja a mesma que a dos seus: a falta da tal "ideia geral".

O tema principal da novela é a morte iminente, bem como duas coisas ligadas a ela: o medo e o sentir-se a personagem na situação em 
que o tempo de vida se aproxima do seu termo. E, se olharmos dessa perspectiva, então os limites da novela são abertos a la Tchékhov; os apontamentos iniciam-se quando Nikolai Stepánovitch já se fizera um diagnóstico; vêm-lhe pensamentos angustiantes durante um tempo desconhecido pelo leitor, a insónia torna-se o seu estado habitual, e um complexo estado psíquico torna-se patente. Não há nenhum episódio concreto que haja provocado isso. Tal acontecimento poderia ter sido, por exemplo, o facto de o professor haver-se descoberto portador duma doença mortífera, mas como e quando tal se deu, tchekhovianamente, está fora dos seus apontamentos, fora da obra, muito embora isso é que tenha sido o grande momento trágico, o ponto de partida de todas as reflexões de Nikolai Stepánovitch e, possivelmente, o motivo de ele pôr-se a escrever notas.

Apesar de a espera da morte atravessar toda a novela, não se tem a própria morte da personagem no final (à diferença, por exemplo, de "A morte de Ivan Ilitch", de Tolstói, tão frequentemente comparada com "Uma história enfadonha"); o leitor fica a saber tão-somente que, tal qual no início, aquela estava desenganada. A despedida do professor e Kátia parece definitiva a ele próprio, mas, para o leitor, Nikolai Stepánovitch, como antes, segue vivo e, consequentemente, apesar do fim dos apontamentos, a história pode continuar. Assim, nós observamos o mesmo pedacinho cuidadosamente recortado duma vida "individual" e uma determinada etapa sua, que começara havia muito antes e ainda não acabara, sobre o fundo do infinito tempo universal.

A conclusão pela falta duma "ideia geral" por Nikolai Stepánovitch continua a ser considerada, pela imensa maioria dos estudiosos, como a ideia principal da própria novela. Mas, como nela não há nenhuma explicação da própria essência desse conceito, então não há, também, um único juízo acerca de qual ideia o próprio Tchékhov tinha em mente: ideológica, social, religiosa, filosófica ou se as reflexões acerca dela são apenas um sintoma do estado doentio do professor. Não obstante às divergências, suscitadas por essa questão, o caminho, que leva a 
personagem a refletir acerca dela, costuma considerar-se a linha do enredo da obra.

Assim, V. Linkov, partindo da heterogeneidade das reflexões da personagem, assinala dois grupos - as formadoras da dinâmica do desenvolvimento e as "destrutoras', perturbadoras do movimento do sentido (significado) interior, - que a personagem deve descobrir. Às primeiras ele chama "de essência, substância" (сущностные), e são elas , na sua opinião, que constituem a composição; à segundas chama "sintomáticas".

No entanto, nos apontamentos do professor, há fragmentos, breves e desenvolvidos, que com frequência aparecem no texto inesperadamente, sob a afluência de emoções ou associações repentinas, dispersas pelo texto, e não integram a cadeia principal de reflexões e são, nesse sentido, "sintomáticas". Tais fragmentos formam uma cadeia cronológica, e o seu tema desenvolve-se segundo uma lógica, o que nos permite associá-los à segunda linha composicional - as recordações. Ambas as linhas estão ligadas tanto semanticamente, quanto estilisticamente, e, com isso, o procedimento básico torna-se a antítese "antes-agora". Somente condicionalmente podemos considerá-las de enredo: na novela, ação, como tal, não há.

\subsection{A composição dos apontamentos - desenvolvimento das reflexões e estado da personagem}

No fim dos anos oitenta, Tchékhov pensava na criação dum romance, que acabou por não ser escrito; o género da novela correspondia mais aos objetivos do escritor, mas algumas situações, ideias e personagens tornaram-se a base de obras suas, inclusivamente de "Uma história enfadonha". Trata-se dum género mais sucinto, que permite reproduzir rapidamente as variáveis relações da personagem com a realidade e, via de regra, explora não a ação, mas o tempo, o fluxo da 
vida, e possibilita acompanharmos a correlação entre o tempo subjetivo da personagem e o tempo histórico e o universal.

O género, em que a novela está escrita, suscita associações com famosas confissões filosóficas, como a Confissão, de Santo Agostinho, e as Meditações, do imperador Marco Aurélio. As ideias de filósofos acerca da essência da vida, do tempo e de si próprios foram precisamente a premissa para os apontamentos de Nikolai Stepánovitch. O nome de Marco Aurélio encontra-se no texto, e é possível acompanharmos a influência da sua mundividência sobre as opiniões do professor. Tal como para o imperador e Santo Agostinho, para Nikolai Stepánovitch, ele é autor e também personagem dos seus apontamentos.

No entanto, na obra literária, ele constitui apenas personagem, e a forma de escriver é escolhida pelo verdadeiro autor. Com a utilização dos meios do género, cria-se a possibilidade de mostrar a personagem, o curso das suas ideias, dos seus sentimentos e desvairios de dentro, sem avaliação exterior direta. A sós consigo próprio, confessando-se no processo de escrita das notas, ele tenta desfazer o novelo de contradições, em que se transformara a sua existência, aparentemente com a máxima sinceridade pressuposta pelo género. Contudo, ele permanece uma pessoa com todas as fraquezas e erros inerentes ao ser humano e até o autoengano, o qual ele não nota, já que, por força das particularidades da sua personalidade, é incapaz de compreender-se verdadeiramente, ainda mais que a avaliação deste e daquele acontecimento, inclusivamente os acontecimentos do passado, é feita da perspectiva das suas opiniões e objetivos do dia. Tchékhov, ao manter maximamente a subjetividade da novela, dá ao leitor a possibilidade de olhar a personagem de fora; destarte, a própria consciência do narrador, bem como os factos e acontecimentos, são analisados ao mesmo tempo tanto pela personagem, quanto pelo autor.

O leitor atento, notando as insinuações do escritor, vê uma diferença substancial entre o que a própria personagem pensa de si, dos parentes e conhecidos e dos variados acontecimentos da vida, por um lado, e o que a 
opinião objetiva do autor representa, do outro. É possível acompanhar isso, partindo de particularidades da composição e dos meios estilísticos do texto, o que é condicionado pela grande quantidade de citações no nosso trabalho.

A novela tem seis capítulos. O seu desmembramento nessas seis partes, contudo, não coincide nem com a organização do tempo e do espaço, que constituem os três fragmentos principais da composição ${ }^{52}$-a vida na cidade, no inverno (40 páginas), a vida na datcha, na primavera (dois capítulos, 13 páginas), e Khárkov (apenas 1capítulo, 6 páginas). 0 tempo como que apressa o seu curso, fortalecendo a impressão de que se esgota a cada vez mais. Assim, no primeiro fragmento, Nikolai Stepánovitch dá-se meio ano de vida; no segundo, três meses; e no terceiro, ele espera a chegada da morte a qualquer momento.

Os primeiros três capítulos são a descrição dum único dia. Cada qual inicia-se com um relato acerca de parentes e conhecidos, com pensamentos, juízos e recordações do professor; a isso segue-se a descrição de algum acontecimento, diariamente repetido, e termina com uma doentia explosão histérica, depois da qual vem o capítulo seguinte. A transição entre eles é uma pausa, que lembra as das suas obras dramatúrgicas, quando se dá à personagem e ao leitor a possibilidade de "suspirar" e compreender o transcorrido. A personagem não entende os seus repentinos ataques de histeria, tendo-se orientado durante a vida inteira pelo processo mental, e essas fortíssimas sensações físicas e emocionais são completamente novas para ele, incompreensíveis, irracionais, e amiúde não se submetem à sua maneira racional de encarar a vida, uma "composição feita com talento", e com frequência se contrapõem a ela. Por costume, ele tenta dar-Ihes explicação, envolvê-las em palavras e acomodá-las na consciência, distribuídas "por estantezinhas", mas isso não lhe satisfaz. Elas ficam fora do seu

\footnotetext{
${ }^{52}$ De acordo com V. Vdóvin.

Disponível em:.http://samlib.ru/w/wdowin_a_n/chekhov.shtml
} 
entendimento. Vê-se tal processo nos três primeiros capítulos.

Em carta a Suvórin, na caracterização de outra sua personagem, Ivánov, Tchékhov explica a causa de tais acessos sob a perspectiva da Medicina:

O cansaço (o dr. Bertenson também o confirma) não se manifesta apenas em forma de lamento ou sensaçõ de tédio. A vida dum homem cansado não pode representar-se assim:

Ela não é regular. As pessoas cansadas não perdem a capacidade de se exaltar intensamente, mas por pouco tempo, e, além do mais, depois de cada exaltação, começa uma apatia ainda maior. Isso pode ser representado graficamente assim:

A linha descendente, como vocé vê, não segue um plano inclinado, dá-se de outro modo . (102)

Com o auxílio de meios estilísticos, desde o início cria-se a sensação dum círculo fechado - os mesmos acontecimentos, conversas, pessoas, nada muda...

No decurso de toda a narrativa, usam-se verbos no Tempo Presente, do aspecto imperfeito, portanto, e não apenas para designarem ações iniciadas antes e estendidas até ao momento dado, como em:

Como antes, não falo mal; até hoje, posso prender durante duas horas a atenção do auditório. (102)

Mas também para designarem acontecimentos que se repetem diariamente. Nikolai sabe de antemão o que acontecerá e o que Ihe dirão:

Em seguida, corre na frente e abre todas as portas no meu caminho. No gabinete, tira-me cautelosamente a peliça e, nesse ínterim, já consegue comunicar-me alguma noticia da universidade. (107)

E até nos casos em que se descrevem factos isolados: 
Levam a minha excelência para a rua, sentam-na num carro de alugel, transportam-na. Deixo-me levar e, não tendo o que fazer, leio as inscrições à direita e à esquerda. (142)

Surge uma contradição: a vida fica a trocar de pé no mesmo lugar, enquanto o tempo passa sem sentido e sem volta. Apenas no final aparecem dois verbos do Pretérito do aspecto perfeito, o que acentua a excepcionalidade do acontecimento e comunica um admirável e forte efeito de tragicidade.

Como já foi mencionado, a novela começa com a apresentação, pelo professor, do seu "nome" como uma personagem especial, em terceira pessoa. Cria-se imediatamente a impressão de que o "nome" existe por si só, tal qual o "nariz" na novela homónima de Gógol, e possui a sua própria aparência, as suas relações, o seu tempo e espaço. Ele vive à parte e é capaz de "passear tranquilamente" pela cidade. E o retrato, feito pelo professor de si próprio em seguida, é percebido em vivo contraste com o retrato do "nome". O contraste é acentuado lexicamente: "... o nome é belo e brilhante, eu sou pessoalmente apagado e disforme":

Vive na Rússia o emérito Professor Nicolai Stiepánovitch de Tal, conselheiro privado; ele possui tantas condecorações russas e estrangeiras que, nas ocasiões em que precisa usá-las, os estudantes chamam-no de iconóstase. As suas relações são das mais aristocráticas; pelo menos, nos últimos vinte e cinco a trinta anos, não existiu na Rússia sábio famoso com quem não mantivesse trato íntimo. Atualmente, não tem com quem manter amizade, mas, falando-se do passado, a longa lista dos seus gloriosos amigos termina com nomes como Pirogov, Kaviélin e o poeta Niekrassov, que Ihe concederam a sua mais cálida e sincera amizade. É membro de todas as universidades russas e de três estrangeiras. Etcétera e etcétera. Tudo isso e muito e muito mais que se poderia dizer, constitui o que se chama o meu nome.

Esse meu nome é popular. Na Rússia, ele é conhecido por toda a pessoa alfabetizada, e, no estrangeiro, é citado do alto das cátedras, com o acréscimo: conhecido e respeitado. Ele pertence ao número dos poucos e felizes nomes a respeito dos quais se considera de mau tom emitir ataques ou proferi-los em vão em público ou pela imprensa. E assim deve ser. Pois o meu nome está intimamente ligado à noção de homem famoso, ricamente 
dotado e indiscutivelmente útil. Sou trabalhador e resistente como um camelo, e isso é importante, bem talentoso, o que é mais importante ainda. Ademais, seja dito a propósito, sou educado e modesto, um tipo honrado. Nunca meti o meu nariz em literatura ou política, não busquei popularidade em polêmicas com ignorantes, não proferi discursos quer em jantares, quer junto à sepultura de colegas... Em geral, o meu nome científico não tem qualquer mácula, nem do que se queixar. Ele é feliz.

O dono desse nome, isto é, eu, representa um homem de sessenta e dois anos, calvo, com dentadura postiça e tique incurável. Na mesma medida em que o nome é belo e brilhante, sou pessoalmente apagado e disforme. A cabeça e as mãos tremem-me de fraqueza; o pescoço, a exemplo duma heroína de Turguiêniev, parece um braço de contrabaixo, tenho o peito caído, os ombros estreitos. Quando falo ou leio, a minha boca entorta-se para o lado; quando sorrio, todo o meu rosto cobrese de rugas senis, funéreas. Não há nada de imponente no meu vulto lastimável; a não ser o seguinte: quando uscita provavelmente em cada um que me vê um pensamento severo e imponente: "Ao que parece, esse homem não tarda a morrer". (101-102).

Tal divisão atravessa a novela inteira como um leitmotiv, suscitando à personagem ora ironia, ora uma arrogância próxima do esnobismo, mas, com mais frequência, irritação, uma vez que a vida dele nem no plano espiritual, nem no plano da vida corrente, não corresponde ao status oficial, à patente de general, à pessoa de quem se orgulha o seu país. E se antes os esforços para a manutenção do brilho exterior eram percebidos como uma necessidade, uma norma como concessão às convenções da sociedade, agora Nikolai Stepánovitch reage viva e doentiamente à menor manifestação do que lhe pareça falso e roubador dos derradeiros e preciosos momentos de vida. E o brilho da sua glória parece-lhe um escárnio sobre o fundo do tédio habitual e pungente da sua existência cotidiana.

A ideia de que o "nome" sobreviverá a ele, não lhe traz alívio; ao contrário, o professor acha que "foi enganado por ele":

Parece-me ridícula a ingenuidade com que, quando moço, eu exagerava a importância da fama e da condição excepcional de que desfrutariam as celebridades. Sou célebre, o meu nome é proferido com veneração, o meu retrato já foi publicado tanto na Seara como na Ilustração Internacional, li a minha biografia até 
numa revista alemã - mas com que proveito?...Admitamos que seja mil vezes famoso, que seja um herói de quem a minha pátria se orgulhe; em todos os jornais, publicam-se boletins sobre a minha doença, o correio me traz mensagens de simpatia de colegas, alunos e do público em geral, mas nada disso me impedirá de morrer numa cama alheia, angustiado e completamente só... Naturalmente, ninguém é culpado disso, mas pecador que sou, não gosto do meu nome tão popular. Tenho a impressão de que fui enganado por ele (158).

O "nome" é a sua fama mundial, a patente de general, as condecorações, a amizade com pessoas famosas e interessantes, os artigos em jornais e revistas, o criado e os requintados almoços com hóspedes, a sua honorabilidade, o respeito e a admiração dos que o cercam, todos os atributos duma vida digna. O principal epíteto "brilhante" repete-se tanto no início dos apontamentos, quanto no fim:

Agora, o meu nome passeia tranquilamente por Khárkov; daqui a uns três meses, gravado em letras de ouro sobre a tumba, ele há de brilhar como o próprio Sol, e isso quando eu já estiver coberto de musgo. (160)

O "Eu próprio" é a fraqueza, a velhice, a doença letal, o medo, a decepção, a falta de dinheiro e os sentimentos de solidão, humilhação e vergonha. Ele está convicto de que a família espera dele apenas dinheiro e a posição; sob a máscara do respeito, ele nota um desprezo mal oculto (Hnekker e o doutorando), e os seres mais espontâneos e honestos, as crianças, riem-se francamente dele, o que a própria personagem encara com enternecimento, admirando-Ihes a sinceridade, já que se julga digno precisamente de tal tratamento. E o contraste mais vivo: a personagem sofre, ao passo que o "nome" prova felicidade; ela morrerá logo, enquanto o "nome" é imortal.

O tempo, em que ambos não estavam separados, é o mundo anterior, em que o professor se sentia confortável, a existência, com que ele sonhara desde a juventude e conquistara com o seu próprio esforço; enfim, a vida anterior, em que a sua fama e ele próprio coincidiam completamente. Mas o leitor encontra Nikolai Stepánovitch nitidamente 
mudado, e entre o seu mundo de antes e o de agora abriu-se um abismo, e este não para de aumentar, à medida do desenvolvimento da doença. $\mathrm{E}$ o seu meio - família, colegas, universidades e jornais - permaneceram os mesmos de antes, ao passo que ele já era outro e o seu diálogo com o mundo que o cercava, para ele, estava interrompido.

Ele sente que todos os que entraram na esfera da sua vida, tanto os mais próximos quanto os mais distantes, dirigem-se não a ele, escrevem não acerca dele e tratam não com ele, pessoa doente e sofredora, mas com o seu "nome", com a sua glória e títulos. E o primeiro (e, portanto, principal) desejo, que the vem à mente, quando ele decide examinar-se é:

Quero que as nossas esposas, filhos, amigos, alunos, amem em nós não o nome, a firma, a etiqueta, mas a pessoa comum. (159)

É um desejo caro também ao próprio Tchékhov:

O caso é o seguinte. O senhor e eu gostamos das pessoas comuns; já os outros gostam de nós pelas pessoas extraordinárias que vêem em nós. A mim, por exemplo, convidam a tudo que é lugar, em toda a parte dão-me de comer e beber, como a um general num casamento; a minha irmã fica indignada de a convidarem a todos os lugares só por ela ser irmã dum escritor. Niguém quer gostar das pessoas comuns em nós. ${ }^{53}$

A situação de rompimento da personagem com a sua mundividência anterior e, em consequência dela, com o seu meio é típica de muitas outras de Tchékhov, como Ivánov, Voinítskii e outras; já as causas de tal ruptura podem ser várias.

Assim, no caso de Dmítrii Gúrov ("A dama do cachorrinho"), é um amor inesperado, que o fizera renascer completamente. Do mesmo modo como Nikolai Stepánovitch, Gúrov continua a viver no mesmo mundo, que

\footnotetext{
53 SUVORIN 24 или 25 ноября 1888 г. Москва. http://royallib.com/read/chehov_anton/tom_21_pisma_ 1888_1889.html\#245760
} 
em tempos fora sangue do seu sangue - familiar, confortável, no qual ele antes vivia perfeitamente integrado com o seu comportamento, hábitos e opiniões. O seu círculo consistia em pessoas como ele, que se compreendiam maravilhosamente e falavam a mesma língua, com a cínica filosofia de vida, na qual as mulheres são uma raça inferior e na qual peixe fresco e mulher bonita são coisas da mesma ordem. Mas, tendo-se apaixonado de verdade, ele de repente é tirado do círculo rotineiro, começa a ver e a sentir de maneira diferente, deixa de perceber a linguagem habitual. E quando, certa vez, dominado pelo desejo de contar a uma pessoa qualquer do seu amor e, não resistindo, enceta a conversa, o seu interlocutor, capaz de perceber as palavras acerca duma mulher encantadora somente no contexto dum relato ligeiro acerca do prazer dos sentidos ou físico, associa isso a outro prazer dos sentidos, da mesma ordem para ele - comida boa e peixe fresco. E basta o conhecido continuar o diálogo, normal e natural para ambos antes, no mesmo tom, para que Gúrov se tome de frustração - a frase do interlocutor parece-lhe dum ultraje selvagem e suscita-Ihe um fluxo inteiro de pensamentos irados acerca da vida e do espírito tacanho dos que o cercam.

Certa vez, à noite, saindo do clube dos médicos, em companhia de um funcionário, seu parceiro no jogo, não se conteve e disse -Se soubesse que mulher encantadora eu conheci em Ialta!

O funcionário sentou-se no trenó e partiu, mas, de repente, voltou-se e chamou-o:

- Dmítry Dmítritch!

- Que é?

- Você tinha razão: o esturjão não estava de todo fresco!

Aquelas palavras, tão comuns, deixaram Gurov indignado, sem que soubesse por que, pareceram-Ihe humilhantes, impuras. Que selvagens costumes, que rostos! Que noites estultas, que dias desinteressantes, anódinos! $O$ jogo desenfreado, a gula, a bebedeira, as imutáveis conversas sobre o mesmo assunto. As ocupações desnecessárias e as conversas invariáveis ocupavam a melhor parte do tempo, as melhores energias e, por fim, sobrava apenas uma vida absurda, sem asas, uma mixórdia qualquer, da qual não se podia fugir, como se se estivesse num manicômio ou numa prisão! ${ }^{54}$

\footnotetext{
${ }^{54}$ A TCHÉKHOV. A Dama do cachorinho, Editora 34, 1999, tradução de B.Shnaiderman, p.325.
} 
O caso aqui, como o de Nikolai Stepánovitch, é que, sob a ação de alguma causa séria, o mundo interior da pessoa muda, e o exterior, em que ela continua a viver, permanece o mesmo.

Fazendo o seu retrato, no início dos apontamentos, o professor detém-se no decréscimo e enfraquecimento do seu intelecto.

\begin{abstract}
Mas escrevo mal. Aquelle pedacinho do meu cérebro que dirige a capacidade de escritor recusou-se a servir. A minha memória enfraqueceu, os pensamentos não têm a necessária continuidade, e, quando os exponho no papel, vem-me cada vez a impressão de ter perdido o sentido da sua ligação orgânica, a construção é monótona, a frase, tímida e avara.

Muitas vezes, não escrevo o que quero, quando escrevo o fim, já esqueci 0 princípio. Frequentemente, esqueço palavras corriqueiras, e sempre tenho de perder muita energia, para evitar frases supérfluas e incisos desnecessários; ambos os fatos testemunham uma queda de atividade mental. E, o que é de admirar, quanto mais simples é o escrito, tanto mais torturante a minha tensão. Escrevendo um artigo científico, sinto-me muito mais livre e inteligente que ao compor uma carta de parabéns ou um ofício. Mais ainda: é mais fácil para mim escrever em alemão ou inglês do que em russo.(102)
\end{abstract}

No trecho, está diante de nós um médico profissional, que descreve os sintomas da doença, Historia morbi, em termos secos, exatos e objetivos. Ele ainda não deu o dagnóstico e está apenas a analisar o curso da moléstia. Mas, como já assinalámos, para o autor e, portanto, para o leitor, tal episódio possui um significado complementar - pormenores, que não podemos deixar de considerar - a falta de nexo nas ideias, o enfraquecimento da memória (principalmente, já que tem que ver com as recordações) e o facto de, às vezes, a personagem escrever não o que quer.

Para além disso, é preciso notar que lhe sai da pena mais fácil e livremente o que está mais próximo das suas ocupações profissionais, de determinadas ações padronizadas, do trabalho em idioma estrangeiro e do que lhe é maximamente alheio. Já aquilo que esteja mais perto da vida corriqueira, como um cartão de parabéns na língua materna, mete-o em 
certa dificuldade.

No decurso dos três primeiros capítulos de "Uma história enfadonha", descreve-se um longo dia de inverno. Basta um único dia para apresentar-se uma rotina diária, tediosa e esvaziada de sentido. A personagem fala de si, dos seus horários (noite, manhã, tarde, anoitecer, noite de novo), da família, dos colegas e da universidade e estende-se longamente acerca do teatro e mulheres.

Com o léxico desses capítulos enfatizam-se o retardamento, a insignificância e a monotonia dos acontecimentos e o tédio, que se instalara na alma do professor: maquinalmente, tempo penoso, enjôo, obrigo-me, sempre o mesmo, estou frio, andando de um canto a outro do quarto, sombrio, aborrece, velhice, fuligem, o aspecto merencório, pessimismo.

Há, é verdade, em tais capítulos, também um léxico diferente pelo colorido emocional, usado em episódios isolados (por exemplo, em algumas recordações). Sobressaindo sobre o fundo monótono geral e em combinação com o ritmo mudado, ele carrega um sentido completamente diferente e desempenha um papel inteiramente diferente. Nisso ainda nos deteremos mais adiante.

Tendo apresentado, no início dos apontamentos, o seu "nome", a si e as alterações físicas, que a doença lhe trouxera, ele passa a uma descrição minuciosa do seu dia cotidiano. E começa-a com a noite, uma vez que a noite, com a insônia que o extenua, se torna o principal fator atormentador, o ponto de partida de tudo o que é mais terrível, incompreensível e anormal na sua vida.

A insônia é um estado que lembra a paz eterna, como que suspenso entre a vida e a morte. Na escuridão e no silêncio, tudo parece mudado, à cabeça vêm pensamentos novos, nada alegres para um moribundo, e o único meio de livrar-se deles por um tempo é fazer algo maquinalmente contar, ler não importa quê ou andar dum canto a outro. Uma noite insone é um tempo em que a inelutabilidade do fim próximo se sente de maneira especialmente real. E a única coisa salvadora, compreensível e querida 
torna-se algum som familiar, ou imagem, ou movimento - o efêmero fio de ligação com a vida genuína, que se encontra além dos limites da noite e da insônia. Não à toa, falando de sons que nos chegam aos ouvidos, Tchékhov usa o verbo "любить" (adorar, amar), emocionalmente mais forte do que o "gostar", escolhido pelo tradutor:

Люблю прислушиваться к звукам (254)

Gosto de prestar atenção aos sons

Quando ao meu modo de vida atual, devo notar em primeiro lugar a insônia, de que sofro ultimamente. Se me perguntassem: o que constitui agora o traço principal, básico, da sua existência? - eu responderia: a insônia. Como outrora, seguindo o costume, eu me dispo exatamente à meia-noite e deito-me no leito. Adormeço depressa, mas acordo depois da uma, com a sensação de não ter dormido absolutamente nada. Torna-se necessário erguer-me da cama e acender o lampião. Passo uma hora ou duas andando de um canto o outro do quarto e examino quadros e fotografias há muito conhecidos. Quando enjôo de andar, sento-me à mesa. Permaneço ali imóvel, sem pensar em nada e não sentindo qualquer desejo; se tenho um livro na frente, aproximo-o maquinalmente de mim e leio-o sem qualquer interesse. Assim, não faz muito tempo, li maquinalmente um romance inteiro, com o estranho nome: Aquilo sobre o que cantava a andorinha. Ora, procurando ocupar a minha atenção, obrigo-me a contar até mil, ora imagino o rosto de alguém dos meus amigos e ponhome a recordar: em que ano e em que circunstâncias ele ingressou no funcionalismo? Gosto de prestar atenção aos sons. A dois quartos de mim, a minha filha Lisa profere algo rapidamente, delirando, minha mulher atravessa a sala de vela na mão e invariavelmente deixa cair uma caixa de fósforos, range um armário ressecado ou inesperadamente o pavio da lamparina passa a zunir - e todos esses sons por alguma razão me perturbaram.

Não dormir de noite significa ter consciência, a cada momento, de ser anormal, e por isso espero com impaciência a manhã e o dia, quando tenho direito de não dormir (103).

Mas eis que, finalmente, põe-se a cantar o galo longamente esperado, chega a manhã, indiferenciável de todas as precedentes e enche-se da azáfama corriqueira, e, um após o outro, e um após o outro, e surgem personagem conhecidas do professor e desconhecidas do leitor (a esposa, a filha, o filho, que aparece somente na conversa da mãe com pai e nos pensamentos deste), o vigia Nikolai, o colega Piotr Ignátich e 
alguns estudantes; em seguida, descreve-se o caminho da universidade e as aulas.

No segundo capítulo (a segunda metade do mesmo dia), o professor trabalha em casa, e vêm ter com ele alguns colegas de universidade, o estudante preguiçoso, o doutorando, Kátia e Hnékker e descreve-se o almoço. E no terceiro capítulo (noite do mesmo dia), uma nova personagem, Mikhail Fiódorovitch, Kátia e o jantar.

É preciso notar que, de todas as aparições duma personagem após a outra, apenas Kátia é evidenciada por uma estilística especial.

Eis o quarto, e eu ouço passos conhecidos, um frufru de vestido, uma voz querida... (117)

Embora a aparição dela seja a corriqueira de todos os dias, como, aliás, de todas as outras personagens, o carinho e a emoção, que de repente notamos no tom de Nikolai Stepánovitch, prepara-nos para o facto de que a Kátia fora destinado um papel especial no texto. E confirma-o o relato, que se segue, acerca da sua vida.

A rotina e monotonia dos acontecimentos diários enfatiza-se, como já foi assinalado, por verbos do Tempo Presente e frases características:

diz sempre o mesmo

Todas as manhãs, é o mesmo

A experiência cotidiana

A nossa conversa acaba sempre da mesma maneira

Visto-me e sigo pelo caminho que me é conhesido há trinta anos.

A frase-chave, referente a tudo o que acontecia, é aquela que dirige à esposa:

Não sou profeta, mas sei de antemão qual será o assunto. Todas as manhãs, é o mesmo. (104)

Nikolai Stepánovitch como que olha com alheamento para o que outrora the fora caro e querido; parece-lhe que mudara não ele, mas o mundo e as pessoas à sua volta, e essas mudanças suscitam-Ihe uma 
crescente irritação.

No primeiro capítulo, no tom da personagem sentem-se uma irritação por enquanto leve com a esposa e uma queixa contra os filhos. A esposa passa da "airosa Vária" a "uma balofa velha desajeitada" e aperreia-o com ninharias da vida, e a filha e o filho não agem do modo como ele gostaria, e nem de longe Ihes ocorre o pensamento de sacrificar os seus ornamentos, ocupações e trabalhos por ele (afora esses pensamentos no filho, o professor não torna a recordá-lo). Na verdade, a fonte da sua indignação é um sentimento de culpa, que o atormenta insconcientemente. Na sua convicção de que o mundo é ruim, na queixa contra a esposa, a filha e o filho e na acusação contra eles de mesquinhez e indiferença, transparecem tentativas de justificação e reabilitação de si e da sua indiferença por eles. Apesar de não reconhecê-lo, Nikolai Stepánovitch culpa-se a si por essas ideias "mesquinhas"; a ele, como antes, o importante é tomar consciência de si da maneira habitual, a única que ele considera digna:

Somente um homem estreito ou enfurecido pode ocultar em si um sentimento mau contra gente comum, pelo fato de não serem heróis. (106)

Isso também tem que ver com a ciência. A ele parece que também naquele momento a ciência era a principal coisa que ocupava os seus pensamentos, e de jeito nenhum "questões sobre as trevas de alémtúmulo". Ele esforça-se insistentemente por convercer-se de tal:

Emitindo o suspiro derradeiro, ainda hei de crer que a ciência constitui o mais importante, o mais belo, o mais necessário na vida do homem, que ela sempre foi e será a manifestação mais elevada do amor, e que somente por meio dela o homem vencerá a natureza e a si mesmo. (113)

No entanto, os apontamentos subsequentes provam o contrário; o mundo antigo "fizera-se em pedaços", a ciência já não é para ele o que preenchia todo o seu ser, bem como as suas ideias e sentimentos, 
levando-o para longe da realidade da existência. O que, agora, constitui a sua presente vida interior, o que o persegue e atormenta e aquilo a que são dedicadas as páginas do seu diário, são precisamente as questões acerca do "objetivo final do cosmo".

Muda tudo o que antes era o sentido da sua vida, fonte de alegria e inspiração. Em lugar do "doce langor", nas aulas ele experimenta sofrimento ("experimento apenas tortura"). O professor compreende que, por força do seu estado físico e psíquico, ele já não dá conta da tarefa e que deveria aposentar-se; sente vergonha, e a consciência atormenta-o, mas, só de pensar nisso, prova um verdadeiro terror; a reforma (aposentadoria) é para ele igual à morte. Ocorrem-Ihe pensamentos terríveis, e tem início uma "ruptura" histérica:

Algo estranho comigo, em consequência da insônia e da tensão e luta com a crescente fraqueza. Em meio à aula, lágrimas me vêm de repente à garganta, os olhos começam a comichar, e eu sinto uma vontade apaixonada, histérica, de estender as

mãos para a frente e queixar-me alto. Quero gritar com voz sonora que eu, um homem célebre, fui condenado pelo destino à pena de morte, e que passado cerca de meio ano, o patrão desta sala já será um outro. Quero gritar que estou envenenado; novos pensamentos, que eu não conhecera antes, envenenaram os últimos dias da minha vida e continuam a picar-me o cérebro, qual mosquitos. Nessas ocasiões, o meu estado me aparece tão terrível que dá vontade de que todas os meus ouvintes se horrorizem, ergam-se num salto e, presas de pânico, se lancem com um grito desesperado para a saída.

Não é fácil sofrer tais momentos. (113)

Nesse episódio, que fecha o primeiro capítulo, concentram-se alguns elementos já aparecidos antes. Ele recorda que é famoso, levando-nos de volta ao início dos apontamentos. Algumas frases repetem-se quase literalmente:

picar-me o cérebro, qual mosquitos. (113)

Estremeço como se uma abelha me picasse (113)

Quero gritar que estou envenenado; novos pensamentos, que eu não conhecera antes, envenenaram os últimos dias da minha vida. (106)

Tais pensamentos sobre os meus filhos me deixam envenenado. 
Paralelamente às ideias acerca da morte, novamente soa a palavra "insônia", fechando, desse modo, o círculo do primeiro capítulo.

Tchékhov sói usar de repetições e variações, que passam de um texto a outro. Assim, por exemplo, foi notada pelos estudiosos a semelhança de situação, pormenores e episódios de "Uma história enfadonha" e o conto "O bispo", escrito quinze anos depois.

No segundo capítulo, vem para o primeiro plano a aguda sensação de falsidade, sentida pela personagem.

São de uma falsa cortesia as suas relações com os colegas; com falsidade age o estudante preguiçoso, tentando justificar a sua ociosidade; com falsidade age o doutorando, que esconde, sob a máscara de respeito à celebridade, o desprezo pelo professor; igualmente falsos são Liza, a esposa e Hnekker.

O léxico escolhido pelo autor agudiza a nossa atenção precisamente a isso:

Em primeiro lugar, procuramos mostrar um ao outro ...(114)

Rimos, embora não tenhamos dito nada de engraçado. (114)

não podemos deixar de dourar nossa conversa com chinesices no gênero... (114)

eu finjo...(114)

...o meu rosto continua a sorrir, provavelmente por inércia(114)

O argumento que todos os prequiçosos trazem em seu auxílio é sempre o mesmo: eles se saíram admiravelmente em todas as matérias e levaram bomba somente na minha, o que é tanto mais surpreendente, pois eles estudaram sempre a minha matéria com grande aplicação e sabem-na muito bem; e a bomba é a consequência de um equívoco incompreensível. (115)

Este expressa um profundo respeito pelo meu nome famoso, pelo minha ciência, mas nos seus olhos eu vejo que ele despreza a minha voz, a minha lamentável figura e a gesticulação nervosa.(117)

Eu, por exemplo, não posso de maneira alguma conformar-me com expressão triunfal que aparece em minha mulher sempre que Hnekker está em nossa cas, não posso tambeém conformar-me com as garafas de Lafitte, vinho do Porto e xerez, postas na mesa

unicamente em sua intenção, para que se convença com seus próprios olhos como vivemos farta e luxuosamente. Não suporto 
também o riso sacudido de Lisa, que ela aprendeu no conservatório, eu seu jeito de entrecerrar os olhos, quando há homens em nossa casa. (128)

O rosto de minha mulher reflete solenidade, uma imponência postiça e a costumeira preocupação. (127)

Hnekker alimenta-se com gravidade, graceja com gravidade também e ouve com ar condescendente as observações das moças (128)

$E$ até o que antes eram sinais naturais da cortesia e respeito, usados no seu círculo, são agora percebidos por ele como um espetáculo geral, em que está obrigado a participar, já não desejando-o.

À medida da piora do seu estado físico, a sua irritação cresce ainda mais. E sob o efeito do vinho bebido no almoço, começa a parecer-Ihe que o seu "nome" é o que o eleva acima da mesquinhez e o espírito tacanho da vida que o cerca. No seu tom, sente-se um esnobismo mal disfarçado:

...em presença de gente como Hnekker, os meus méritos parecem-me uma montanha altíssima, cujo cume desaparece nas nuvens e ao pé da qual se movem uns Hnekker quase imperceptíveis. (129)

Semelhante cena aparece, masi tarde, em "O tio Vánia", quando o doutro Ástrov, acalorado pela vodca, profere um monólogo parecido:

Nessas horas tenho meu próprio sistema filosófico e vocês, amigão, todos vocês, não passam de uns pequenos insetos a meus olhos... uns micróbios. ${ }^{55}$

Sobre tal fundo, como contraste aparece um pequeno pormenor. Recordando Kátia ainda menininha, Nikolai Stepánovitch assinala "a confiança extraordinária" dela e com que sincero interesse e curiosidade ela encarava a vida.

Tal como no primeiro capítulo, com os mesmos meios estilísticos - o ritmo monótono, o tempo presente dos verbos e o léxico - salienta-se a

\footnotetext{
55 TCHÉKHOV, Anton. Teatro I. A Gaivota, O tio Vania, Veredas, 2009. Tradução de Gabor Aranyi, p.89
} 
rotina, que havia muito já o enfadara:

Assim como aconteceu de manhã, sei de antemão o assunto da nossa conversa (129)

o soalho sombras conhecidas e que me enjoaram há muito (130)

Segue-se a contraposição "antes-agora". Nikolai Stepánovitch compara os almoços de antes com os do momento presente, a pequena Kátia com a mulher adulta. $\mathrm{E}$, do mesmo como o primeiro, o segundo capítulo fecha-se com uma ruptura histérica, e a par de pensamentos na morte ("tenho medo de morrer de repente"), a personagem recorda a sua insônia:

já está começando a minha maldida insônia.(130)

O terceiro capítulo é um serão na casa de Kátia. A atmosfera relaxante, langorosa, e a companhia do ser mais caro predispõem a uma conversa franca. E Nikolai Stepánovitch conta a Kátia o que estava a passar-se com ele, expõe-Ihe o que representa a sua filosofia de vida e compartilha com ela as suas torturantes questões e dúvidas e a incompreensão da causa de a sua mundividência anterior estar a tornar-se impossível na sua presente situação.

O melhor e mais sagrado direito dos reis é o direito de perdoar. $\mathrm{E}$ eu sempre me senti rei, pois usei ilimitadamente esse direito. Nunca julguei os demais, era condescendente, perdoava de bom grado a todos. Onde outros protestavam e indignavam-se, eu apenas aconselhava e procurava convencer.

A vida inteira, esforcei-me apenas para que a minha companhia fosse tolerável para a família, os estudantes, os colegas, os criados. E essa minha relação com as pessoas, eu sei, educava a todos os que se aproximavam de mim. Mas agora não sou mais rei. Dentro de mim está acontecendo algo que só é decente para os escravos: pensamentos maus fermentam-me na cabeça dia e noite, e sentimentos que eu não conhecia trançaram seu ninho em minha alma. Eu odeio, desprezo, indigno-me, fico furioso, temo. Tornei-me desmedidamente severo, exigente, irritado, descortês, desconfiado. Mesmo aquilo que, em outros tempos, dava-me apenas a oportunidade de dizer mais um trocadilho e rir com bonacheirice desperta-me agora um sentimento penoso. Mudou em mim também a minha lógica: antes, eu desprezava apenas o 
dinheiro, mas agora tenho um sentimento mau não em relação ao dinheiro, mas ao ricos, como se eles tivessem culpa; antes, eu odiava a coação e o desmando, mas agora odeio os homens que empregam a coação, como se eles fossem os únicos culpados, e não todos nós que não sabemos educar-nos mutuamente. $O$ que significa isso? Se os pensamentos e sentimentos novos resultaram da mudança de conviç̧ões, de onde pode ter surgido essa mudança? Teria o mundo se tornado pior, e eu melhor, ou antes eu era cego e indiferente? (132)

Mas que é que eram esses princípios de vida, por que Nikolai Stepánovitch se norteara no decurso de muitos anos?

Os juízos filosóficos de Tchékhov constituem um tema extremamente discutível nos estudos literários.

Tradicionalmente, encara-se a filosofia em literatura como um mundo de ideias, porém Tchékhov não tinha ideologia como tal, bem como não tivera uma educação filosófica (à diferença de L. Tolstói). E, quando as suas personagens citam argumentos "a favor" e "contra" alguma ideia, elas expressam não a opinião do autor (como nos romances de Dostoiévskii), mas a sua própria, e o objetivo da discussão delas, para o escritor, não está na busca da verdade ideológica, mas, com mais frequência, na caracterização das personagens e das suas inter-relações.

É sabido, contudo, que a filosofia e autores como A. Schopenhauer, W. Goethe, Henry Thomas Buckle e H. Spencer, bem como Marco Aurélio, Epítetoe e Blaise Pascal, citados em "Uma história enfadonha", durante muito tempo estiveram na esfera de interesses de Tchékhov.

Em Ialta, na biblioteca da casa-museu do escritor, encontra-se o livro "Reflexões do imperador Marco Aurélio acerca do que é importante para a pessoa própria", em tradução do príncipe L. Urússov e edição de 1882, na cidade de Tula. Nas margens de muitas páginas, pela mão de Tchékhov, com três tipos diferentes de lápis (dois com grafite de dureza diferente e um vermelho de ponta mole), foram feitas notas, que refletiam a temática de parágrafos isolados: "deus", "vida", "natureza", "morte" etc. Encontram-se muitas citações dos nomes de Marco Aurélio e Epíteto (e dos estóicos tardios) também nas cartas do escritor, inclusive durante 0 período de escrita de "Uma história enfadonha". Tudo isso e, 
principalmente, as numerosas invocações dos clássicos do estoicismo, nas obras de Tchékhov atestam o interesse do escritor por essa filosofia.

É possível vermos imediatamente um paralelo tanto nos temas tratados (vida, morte, tempo etc.) quanto em frases concretas. Claramente, Nikolai Stepánovitch construía a "composição" da sua vida, guiando-se pelas posições filosóficas dos estóicos.

$\mathrm{Na}$ personagem, com cada vez mais força, inflama-se uma luta entre o desejo de, como antes, sentir-se um "rei", ser condescendente e justo e os novos pensamentos "de escravo". Com a sensação da própria hipocrisia, mas sem querer reconhecê-la, e com o desejo irresistível de criticar a todos e tudo, ele, cego para as próprias contradições, dirige toda a sua insatisfação e ira contra os que o cercam, acusando-os, indignandose com o comportamento da esposa:

e até me calo quando ela emite juízos injustos a respeito das pessoas... (105)

ou com o cinismo e a maledicência de Kátia e Mikhail Fiódorovitch.

Assim, a sua tentativa de interceder pelos novos estudantes transforma-se em mais uma crítica a eles, e a repentina queixa contra a filha contradiz o que ele próprio pensa dela.

Quando alguém não compreende, ele sente dentro de si uma desarmonia e não procura as causas dessa desarmonia dentro de si próprio, como seria necessário, mas no mundo exterior. (146)

A descrição dos acontecimentos diários entremeia-se de recordações e digressões-reflexões. As mesmas reflexões acerca do teatro, literatura, juventude, música, mulheres etc., que a crítica atribuía ao próprio Tchékhov. Apesar de, em algumas cartas do escritor, realmente podermos verificar análogas disposições de espírito, o que é substancial, aqui, são não os temas aventados em si, mas o modo de a personagem encará-los; é difícil não notarmos que não somente as pessoas, senão também 
quaisquer acontecimentos da vida, da arte ate às ninharias do cotidiano, tudo se submete a uma ácida crítica por ele.

Precisamente, a incapacidade de superar a contradição entre o próprio estado e a costumeira posição de vida provoca nova explosão emocional. O pensamento da personagem vai da acusação de todos e de tudo que o cerca, "rabugice" (pela definição de Tchékhov, dada numa das suas cartas) por conta da vida insatisfatória, à compreensão de que a causa está nele próprio, nos seus novos pensamentos.

No fim do capítulo, ele é inteiramente honesto consigo:

Penso em mim mesmo, na minha mulher, em Lisa, em Hnekker, nos estudantes e nas pessoas em geral; penso de maneira má, mesquina, trapeceio comigo mesmo... (141)

Está claro que os pensamentos novos, araktcheievianos, não estão estão em mim casualmente, nem são temporários, mas que dominam todo o meu ser. (142)

Exatamente como nos dois primeiros capítulos, no final do terceiro, paralelamente a pensamentos acerca da morte, aparece a palavra insônia, só que agora especialmente sublinhada: dum lado, travessão (ausente na tradução brasileira), do outro, reticências. Mas, o que é o mais importante, ela encontra-se numa posição forte do texto - num último parágrafo à parte - e é a última palavra do terceiro capítulo e do primeiro fragmento da composição. O círculo fecha-se: o longo dia começa e termina com insônia.

...e penso que em breve a morte há de me levar. (142)

Em seguida, a insônia. (142)

А потом - бессоница... 56

O quarto capítulo inicia-se com as palavras:

Chega o verão, e a vida se modifica. (142)

${ }^{56}$ A. Tchékhov, Moscou,1977, p.291. 
A primeira frase, sublinhada na forma de parágrafo isolado, parece carregada de esperança. No entanto, podemos logo notar que, como se em ritmo acelerado, os mesmos acontecimentos desenvolvem-se na mesma ordem vista nos capítulos anteriores, aparecem as mesmas personagens, uma após a outra, e soam diálogos paralelos aos primeiros capítulos. Nikolai Stepánovitch alude de passagem ao seu "nome", tal como fizera no primeiro capítulo, na terceira pessoa:

Levam a minha excelência para a rua, sentam-na num carro de aluguel, transportam-na. (142)

Em seguida, cita a insônia e descreve minuciosamente o seu plano de atividades para o dia. Seguem-se reflexões em estilo pesado (тяжеловестные) acerca de literatura e crítica.

Surge Nikolai, porteiro da universidade, depois, Piotr Ignátievitch. E, novamente, almoço, ao qual, para além da personagem, estarão presentes a esposa, Liza e Gnekker.

Após a refeição, Nikolai Stepánovitch, como no primeiro capítulo, fuma cachimbo no seu gabinete, entra a esposa e põe-se a falar de Hnekker, com referências desagradáveis a Kátia, e após isso sobrevem a Nikolai Stepánovitch uma crise de histeria. A segunda parte do quarto capítulo é dedicada a Kátia: a conversa com ela, o aparecimento de Mikhail Fiódorovitch, o mesmo jantar, como no inverno, com a mesma comida, com os mesmos baralhos de cartas e com a mesma maledicência.

De volta à primeira frase desse capítulo, ao leitor pode parecer que ela é irônica: aparentemente, nada mudara, tudo continua o mesmo, e o quarto capítulo representa o conteúdo sucinto dos três primeiros.

Bem no início dele, há um pequeno episódio:

Deixo-me levar e, não tendo que fazer, leio as inscrições à direita e à esquerda. A palavra "traktir" transforma-se em "ritkart". Isso serviria para o sobrenome de baronia: a baronesa de Ritkart. (142) 
As mesmas letras, a mesma palavra, mas ela, lida ao contrário, produz um significado completamente diferente: a natureza tão terra a terra duma taberna torna-se o nobre sobrenome duma baronesa (essa baronesa Ritkart é mencionada de passagem em outro conto, da fase incial, de Tchékhov - "Uma alminha liberal' - "Либеральный душка"). О autor aguça a nossa atenção com os sinais costumeiros: os mesmos acontecimentos, as mesmas personagens e os mesmos diálogos entre elas formam um novo sistema e delineia-se um novo quadro; há algo mal perceptível mas já mudado.

Sobretudo, como já assinalámos, muda o ritmo: a descrição dos acontecimentos já conhecidos torna-se mais curta, e o seu transcurso acelera-se, o que é ressaltado com a aparição duas vezes, no texto, duma viagem - uma com cocheiro, a outra com Kátia num charabã.

E a par de verbos no presente e do léxico, os quais, como antes, criam a atmosfera de monotonia e repetitividade, surgem sinais linguísticos, que pressupõem a excepcionalidade dos acontecimentos.

Uma bela manha

não vêm todos os dias

Ocorrem agora também equívocos de que antigamente eu tinha noção apenas de outiva. Por mais que me envergonhe, vou descrever um que aconteceu há dias, depois do jantar.

Exatamente como, nos primeiros capítulos, se observa a antítese "antes-agora", mas, no quarto, o "antes" já significa não o passado mais distante, senão o de pouco tempo atrás, do último inverno:

O nosso jantar decorre de maneira mais cacete que no inverno (147)

Ocorrem mudanças também nas personagens:

Nicolai aparece geralmente nos feriados, como que para tratar de serviço, mas principalmente para me ver. Vem bastante embriagado, o que nunca the acontece no inverno. (145)

Há muito tempo já que Mikhail Fiódorovitch devia ter viajado 
para o estrangeiro, mas ele adia a partida cada semana. Nos últimos tempos, aconteceram com ele certas modificações: parece mais acobado, passou a embriagar-se com vinho, o que antes nunca lhe acontecera, e as suas sobrancelhas negras estão começando a branquear. (151)

Antes, eu tolerava a sua presença calado, mas agora dirijo-Ihe alfinetadas, que obrigam minha mulher e Lisa a enrubescer. (147)

Se, no segundo capítulo, após conversa com Nikolai Stepánovitch, a esposa

... aperta um lenço contra os olhos e vai chorar no seu quarto; 130),

então, no quarto:

minha mulher de súbito empalidece e solta um grito alto, com uma voz desesperada, que igualmente não é sua. (148)

No terceiro, ressalta-se a atenciosidade de Kátia em relação a Mikhail Fiódorovitch:

Deve ser Mikhail Fiódorovitch...

Kátia acompanha com atenção as suas jogadas e ajuda-o mais com a mímica do que com palavras. (137)

E, já no quarto, ela já não consegue esconder a sua irritação com a aparição dele:

- De novo este Mikhail Fiódorovitch!- diz Kátia com desagrado.

- Tire-o de perto de mim, por favor! Estou enjoada, ele já se evaporou...Como cansa! (151)

No terceiro, ao conselho de Nikolai Stepánocitch de arranjar um trabalho, Kátia apenas cala e muda a conversa para outro tema; agora, ao mesmo conselho, ela "explode".

A atmosfera geral no quarto claramente torna-se tensa, como se o estado de nervos de Nikolai Stepánovitch se comunicasse às outras 
personagens.

A principal mudança, contudo, ocorre no próprio professor. Ele já não esconde de si nem a sua insuportável irritação, nem o ódio que dele se apodera; as emoções vencem a razão. Paralelamente, têm-se dois episódios: no segundo capítulo, o desprezo a Hnekker gera um pensamento acerca dos próprios méritos e da inalcançável altura deles, enquanto, no quarto, o desprezo chega a tal ponto, que Nikolai Stepánovitch, com consciência da estupidez do seu comportamento, não resiste e recita uma citação das fábulas de Ivan Krylov. Em ambos os casos, figuram imagens do baixo e do elevado; no primeiro episódio, o cume duma montanha e o seu sopé; no segundo, a águia em vôo altíssimo e a galinha incapaz de alçar vôo.

-"Sucede às águias descer mais que as galinhas.

Mas estas nunca hão de subir às nuvens..." (147)

Nikolai Stepánovitch começa já a tomar consciência da inutilidade dos conselhos, dados a Kátia, mas o sentimento de dever em relação a ela, o qual ele entende à maneira antiga, e o hábito de muitos anos obrigam-no novamente a aventar a questão do futuro dela.

Piora o estado físico do professor; ele sofre já não um simples colapso nervoso, mas um profundo desmaio, de duas a três horas de duração.

E mais uma vez de volta à primeira frase do quarto capítulo, compreendemos que a vida, realmente, mudara, só que tais mudanças não trazem nenhuma sensação de alegria e novidade.

A personagem conformara-se definitivamente com os seus "pensamentos de escravo" e adere prazerosamente à tradicional maledicência de Kátia e Minkhail Fiódorovitch. Isso fecha o capítulo quatro.

Pela primeira vez, no fim do capítulo, não há nenhum pensamento na morte, nem a insônia que o acompanha, nem histeria. Por que deixa o 
autor, nesse caso, de usar o mesmo procedimento estilístico, fazendo, no entanto, o leitor compreender que a atmosfera está tensa até ao máximo?

Em primeiro lugar, com isso aprofunda-se a diferença composicional em relação aos três primeiros capítulos (primeiro fragmento composicional), simbolicamente declarada no início do quarto. Em segundo, e isto é o principal, o penosíssimo estado psicológico, que se segue, foi destacado para um quinto capítulo à parte, no qual já não há nem monotonia de acontecimentos, nem reflexões, e a personagem entrega-se ao poder das suas terríveis e incompreensíveis sensações; estas parecem existir por si próprias, contagiando a todos em volta e criando a atmosfera dum medo irracional.

Para além de a ação passar-se à noite, isto é, vermos a insônia da personagem no sentido físico direto, todo o quinto capítulo concentra o significado simbólico da insônia - não é simplesmente um pensamento na morte, mas a duradoura sensação de terror, advinda do facto de que a morte está ao lado e preenche literalmente o espaço.

A própria palavra "insônia" soa novamente no texto como reflexo do estado geral de Nikolai Stepánovitch e como resposta à pergunta acerca do que está a ocorrer:

- O que está fazendo agora?

- Nada... Insônia. (155)

Desde o próprio início do capítulo, está claro que se descreve um acontecimento isolado, e a palavra "uma" e o verbo no tempo passado acentuam-no:

Há noites terríveis, com trovoada, raios, chuva e vento, e que o povo chama de noites de pardais. Em minha vida pessoal, aconteceu uma noite de pardais exatamente desse tipo...(152)

A descrição duma noite de pardais, vivida pelo próprio Tchékhov, encontra-se nas reminiscências do seu irmão Aleksandr. 
Воробьиной ночью в Малороссии называется такая страшная грозовая ночь, что даже воробьи от испуга вылетают из своих гнезд и мечутся как угорелые по воздуху.

Chama-se "noite de pardais", na Ucrânia, a uma noite tempestuosa tão terrível, que até os pardais, de pavor, deixam os ninhos e ficam a voar como doidos. (tradução nossa) ${ }^{57}$

O primeiro parágrafo do capítulo conclui-se com a pausa dumas reticências. Ao leitor é dada a possibilidade de sentir profundamente o texto seguinte em contraste com a frase inicial. "Aquela noite igualzinha" revela-se completamente outra: não há nenhuma tempestade, nem raios, nem vnto, nem trovões, nem chuva, nem pardais ensandecidos. A noite, pelo contrário, é magnífica, sem vento, enluarada, tranquila.

A "tempestade" está é na "vida pessoal" das personagens. E esse contraste entre a natureza bela, indiferente e eterna, dum lado, e os sofrimentos humanos e a finitude da nossa vida, cria, sobretudo, o terror e desconcerto, que repentina e inexplicavelmente se apodera das almas das pessoas:

Está um tempo magnífico. Cheira a feno e a algo mais, muito agradável. Vejo o muro ameado, as arvorezinhas sonolentas e esquálidas junto à janela, a estrada, a faixa escura da mata; no céu, há uma lua tranquila, muito brilhante, e nenhuma nuvem. Quietude, não se move nenhuma folha. Tenho a impressão de que tudo me olha e presta atenção, à espera de que eu comece a morrer. (152)

A natureza, em Tchékhov, aparece com frequência para lembrar-nos da morte.

O insuportável terror, experimentado por Nikolai Stepánovitch, é tão irracional, inexplicável, sem origem conhecida e por alguma razão se apodera imediatamente de todos, que ao leitor se comunica a atmosfera maligna, quase mística.

O quinto capítulo contrapõe-se a toda a novela restante tanto pela posição principal, com que se faz a narrativa, (apenas sensações,

\footnotetext{
${ }^{57}$ Disponivel em: http://www.anton-chehov.info/v-gostyax-u-dedushki-i-babushki.html
} 
sentimentos), quanto pela disposição de espírito comunicada ao leitor, para além do ritmo e do léxico.

Seguindo as leis do género místico, a atmosfera de inexplicável terror aumenta:

Dá medo. Fecho a janela e corro para o leito. Apalpo o pulso e, não o encontrando no braço, e todas essas minhas partes estão frias, pegajosas de suor. A respiração torna-se cada vez mais rápida, o corpo me treme, todas as entranhas estão em movimento, no rosto e na calva há uma impressão como se uma teia de aranha pousasse sobre eles (152)

Sigo a minha mulher, ouço o que ela me diz e, perturbado, não compreendo nada. Nos degraus da escada, pulam as manhãs claras da sua vela, tremem as nossas sombras compridas, as minhas se enredam nas abas do roupão, sufoco e tenho a impressão de que algo me persegue e quer agarrar-me pelos ombros. "Vou morrer neste instante, aqui na escada", penso. "Neste instante"...(153)

Meu deus, que medo! Eu tomaria mais água, mas agora, dá medo abrir os olhos, e eu temo levantar a cabeça. O meu terror é inconsciente, animal, e não posso de modo nenhum compreender por que me espera uma dor nova, ainda não experimentada? (153)

Também o léxico é bem característico:

terrível

minha alma está opressa por tamanho horror

o reflexo sinistro e enorme de um incêndio

Dá medo

teia de aranha

escondo a cabeça sob o travesseiro

tenho sentimento de que a morte acercar-se-á de mim sem falta por trás, devagarinho

meu deus, que medo!

Está gemendo ou rindo

algo me persegue e quer agarrar-me pelo ombros

um uivar de cão

um pio de coruja

os pressentimentos

as profecias

range o portão do jardim

alguém se esgueira ali

as faixas de luar

o rosto pálido, severo e fantástico devido ao luar, como que de mármore 
Os numerosos pronomes indefinidos acrescentam mistério. 0 português "alguém" e a pergunta "quem é?", infelizmente, não transmitem o caráter entrecortado dos sons da frase russa "не то, не то" (nie-tó, nie-tó: nem bem, nem bem; para o que contribui a consoante dura " $\mathrm{t}$ "), do repetido pronome "опять...опять" (opiát'... opiát': novamente), dos pronomes indefinidos "кто-то, что-то" (któ-to, chtó-to: alguém, algo, respectivamente; para o que contribuem as consoantes mudas "k" е "ch") e da pergunta "кто там?" (quem está aí?), consonante com eles; esses sons entrecortados suscitam associação com as batidas aceleradas do coração (que, em português, podem representar-se pela onomatopéia tuc-tuc) e fazem o leitor experimentar quase fisicamente, no subconsciente, as mesmas emoções das personagens.

Repete-se com frequência o som "ô", quase sempre na sílaba da consoante dura $t$ :

Acima do teto, alguém está gemendo ou rindo... Presto atenção. Decorrido um tempo, passos ressoam na escada. Alguém vai apressadamente para baixo, depois [vem] novamente para cima. Pouco depois, os passos tornam a ressoar embaixo; alguém pára junto à minha porta e fica à escuta.

-Quem é? - grito. (153)

No original:

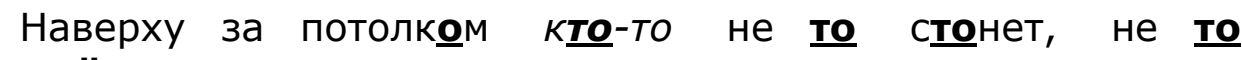
смеётся...

Прислушиваюсь. Немного погодя на лестнице раздаются шаги. Коㅡ-то торопливо идёт вниз, потом опять наверх. Через минуту шаги опягь раздаются внизу : кто-то останавливается около моей двери и прислушивается.

-- Кто там? -- кричу я. ${ }^{58}$
}

Tal qual nos capítulos anteriores, quase todos os verbos, aqui, se empregam no tempo presente, mas, desta vez, eles acentuam não a repetitividade do que ocorre, mas um brusco retardamento do tempo, como se quisessem fixar cada instante. O tempo quase para.

${ }^{58}$ A. Tchékhov, Moscou,1977, p. 301 
Um silêncio de morte, um silêncio tal que, segundo de expressou certo escritor, até zune nos ouvidos. O tempo passa devagar, as faixas de luar sobre o parapeito da janela não mudam de posição, como que petrificadas... Ainda falta muito para o amanhecer. (154)

Silêncio, imobilidade da natureza e do tempo, que lembram a "paz eterna", e, em contraste com isso, vêm as palavras:

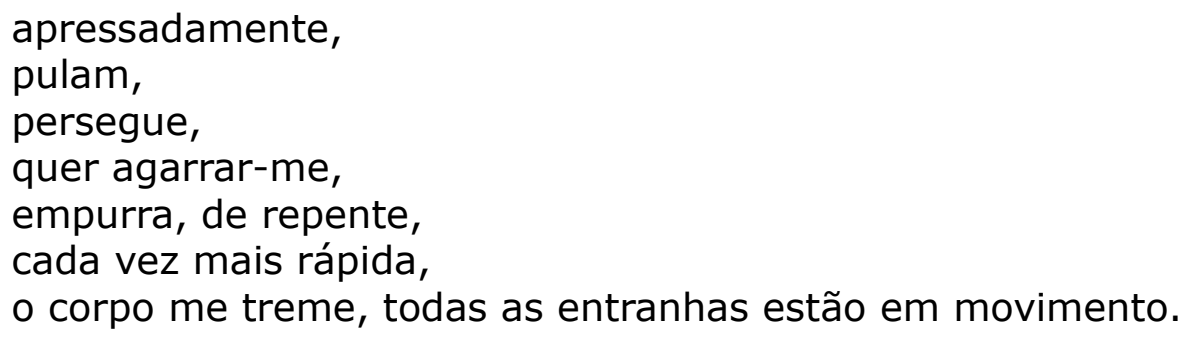

Cria-se a impressão de que as personagens, tomadas de terror, tentam, com ajuda da vanidade (суета), sons e lágrimas, romper essa imobilidade de morte e apressar o tempo, que fora detido.

Produz-se o ritmo intermitente com as frases curtas dos diálogos e os numerosos sinais de pontuação (assim, em quatro páginas, as reticências usam-se 40 vezes, o ponto de exclamação 13 , e o de interrogação 20).

Que fazer? Chamar a família? Não, não é preciso. (152)

-Ah, meu Deus...ah, meu Deus! - balbucia, entrecerrando os olhos por causa da nossa vela. - Não posso, não posso...(153)

- Mas ajude-a, ajude-a! - implora minha mulher. - Faça alguma coisa! (154)

- Desculpe - diz ela. - De repente, não sei por que, tive um sentimento intoleravelmente penoso... Não pude suportar e vim para cá... Havia luz na sua janela, e... eu resolvi chamálo... Desculpe... Ah, se o senhor soubesse como era penoso o que senti! O que está fazendo agora? (155)

A lógica e a razão tornam-se impotentes, ninguém consegue 
compreender o que se passa com elas, e no texto repetem-se as mesmas frases:

não sei por que

perturbado, não compreendo nada

não compreendo

eu não sei

eu não compreendo nada, não sei

não sei por que

A incompreensão, que chega até ao pânico, é transmitida pela quantidade de orações interrogativas:

Por que essa impressão? (152)

Que fazer? Chamar a família?(152)

será porque eu quero viver, ou porque me espera uma dor nova, ainda não experimentada? (153)

Quem é? ... O que você tem?(153)

E, embora Nikolai Stepánovitch, por hábito recorrendo à lógica para salvação, tente explicar uma coisa ou outra, ele não o consegue, e as explicações não Ihe satisfazem.

Como que de propósito, ressoa de repente em nosso pátio um uivo de cão, a princípio suave e indeciso, depois sonoro, a duas vozes. Nunca dei importância a tais augúrios como um uivo de cão ou um pio de coruja, mas agora o meu coração comprimese numa tortura, e eu procuro explicar a mim mesmo esses uivos.

"Bobagem...", penso eu, "influência de um organismo sobre outro. A minha acentuada tensão nervosa transmitiu-se à minha mulher, a Lisa, ao cachorro, eis tudo... Essa transmissão explica os pressentimentos, os profecias..."(154)

À diferença dos capítulos precedentes, aqui não se encontram sinais de manifestação física da doença, e apenas o silêncio, a imobilidade e a magnificência da noite enluarada dão à personagem a sensação de que a morte está próxima. 
Não sei por quê, tenho a impressão de que vou morrer no mesmo instante. Por que essa impressão? No corpo, não há nenhuma sensação que indique um fim próximo, mas a minha alma está opressa por tamanho horror, como se eu tivesse visto de repente o reflexo sinistro e enorme de um incêndio. (152)

Como motivos dominantes, que atravessam todo o texto da novela, os temas principais - morte, medo, doença, tempo - concentram-se maximamente neste capítulo; no entanto, nós não encontramos, aqui, nem longas reflexões monótonas, nem os acontecimentos constantemente repetidos nos capítulos anteriores, os quais suscitam crescente irritação a Nikolai Stepánovitch: aquilo que Ihe parece falsidade, maledicência e cinismo. Os sentimentos direcionados para o subconsciente vêm ao de fora. As pessoas vêem-se cara a cara com a própria vida, com uma força independente delas, e tal força, ao aproximá-las maximamente, obriga-as a ser maximamente sinceras, a ser elas próprias. E elas, alheias umas às outras, vivendo cada qual no seu "estojo", experimentam um estado comum a todas: o de terror e incompreensão. Advém uma aguda necessidade uma da outra. Ademais, o que se passa com elas, é tão próximo da natureza, irracional e independente dos seus pensamentos, que as aproxima daqueles para quem essa força estranha e incompreensível é natural: os animais e as crianças. $O$ autor sugere isso com alguns pormenores: o uivo dum cão ajunta-se às perplexidades humanas:

Como que de propósito, ressoa de repente em nosso pátio um uivo de ção, a princípio suave e indeciso, depois sonoro, a duas vozes. (154)

Não à toa, Nikolai Stepánovitch define o seu medo como um "terror inconsciente, animal". Tal estado obriga as personagens a inconscientemente voltarem ao passado, quando o seu amor mútuo era natural e sincero, àqueles minutos em que os filhos eram pequenos. 
O tempo não somente retarda o seu curso e detém-se, senão também inicia uma contagem decrescente: Nikolai Stepánovitch, de repente, vê os seus entes próximos tais quais eles se haviam conservado na sua memória.

Vendo -me, solta um grito e atira-se ao meu pescoço.

- Meu bondoso papai...- soluça -, meu bom papai... Meu pequenino, meu querido... Não sei o que há comigo... É penoso!

Abraça-me, beija-me e murmura palavras carinhosas, que eu Ihe ouvia quando era ainda criança. (153-154)

Procuro cobri-la, minha mulher dá-lhe de beber, e ambos ficamos acotovelando-nos junto ao leito; o meu ombro empurra o seu, e nesse momento vem-me à memoria como outrora demos banho, juntos, aos nossos filhos.(154)

As suas sobrancelhas se levantam, brilham-lhe os olhos de lágrimas, e todo o seu rosto se ilumina, como que por uma luz, por uma expressão conhecida, há muito não vista, de confiança. (155)

Liza, dirigindo-se ao pai, chama-lhe "крошечка" (pequerrucho), como os adultos podem dirigir-se a crianças.

...meu bom papai... Meu pequenino, meu querido (153)

Palavras de amor, proximidade, união ( $m e u$, nossos) e confiança são um poderoso contraste com o léxico recém-usado de medo, pânico e incompreensão. Como se a vida desse às personagens mais uma possibilidade de compreender, mudar algo e superar o alheamento espiritual de todas.

Contudo, o instante mágico esvai-se, e tal esperança desaparece; tudo retorna aos mesmos círculos, e as personagens, como antes, não são capazes de ouvir umas às outras.

Nikolai Stepánovitch, com dizer "não compreendo nada, não sei, e só posso balbuciar", pensa se não é o caso de passar uma receita e não o faz, e simplesmente espera que os gemidos acima do teto silenciem. Parece-Ihe que também Kátia, ao oferecer-Ihe uma quantia, não ouve uma 
alusão à morte próxima, quando ele diz que o dinheiro agora é inútil para ele. E ele "não logra" dizer-Ihe "adeus".

O quinto capítulo, por muitos meios linguísticos, sobressai claramente de toda a novela. Ele não apenas está construído sobre contrastes (beleza e medo, sombra e luz, solidão e proximidade, paz e pânico), como também está fartamente saturado de símbolos, tanto alguns já encontrados nos capítulos anteriores, quanto outros que aparecem pela primeira vez.

Esse é, sem dúvida, o centro culminante, e o facto de a culminação da novela representar a chegada de sensações humanas ao grau máximo de intensidade, sem nenhuma reflexão racional e sobre o pano de fundo da paz absoluta e da beleza serena e indiferente da natureza, revela que é precisamente nessa contradição que se encerra a principal ideia de toda a obra.

O sexto capítulo, por sua vez, divide-se distintamente em duas partes. Se a primeira delas toma um atalho de volta e, estilística e semanticamente, nos devolve ao estado de espírito dos primeiros capítulos, então a segunda parte, indubitavelmente, leva-nos a uma "noite de pardais".

O pano de fundo básico do sexto capítulo é o completo ensimesmamento espiritual e a indiferença; a monotonia como que tem como moldura duas cenas emocionais: a tensão anterior do quinto capítulo e a chegada de Kátia.

Transcorreu fora do texto dos apontamentos algum lapso de tempo, e de novo mudou o espaço. Se o primeiro centro composicional compreende a vida costumeira e cotidiana na cidade e o segundo é a vida na datcha, repetida anualmente, o terceiro (Khárkov), por sua vez, é uma circunstância completamente nova, que surge pela primeira vez.

Para a personagem, porém, já nenhuma mudança tem sentido e apenas aprofunda a sua solidão.

Se é para viajar para Khárkov, viajemos. Ademais, abso- 
lutamente tanto faz para onde viajar, para Khárkov, Paris ou Bierditchev. (156)

A viagem a essa cidade é citada no primeiro:

-Em suma, Nicolai Stiepánovitch, você deve sem falta fazer uma viagem a Khárkov....

-Se você quer, vá lá, irei a Khárkov. (130)

E no segundo fragmentos composicionais:

...enquanto o tempo está quente e há tempo livre, viajar até Khárkov...

- Está bem, irei... - concordo. (148)

A viagem, contudo, realiza-se no terceiro; ademais, toda a ação do capítulo transcorre no quarto dum hotel de Khárkov. O capítulo inicia-se com uma frase curta:

Estou em Khárkov. (156).

A viagem é feita contra a vontade dele, por razões "formais", pelo sentimento de dever e vergonha em relação à família, e vem a ser um completo malogro - tarde de mais.

A atmosfera é ainda mais penosa e "enfadonha" do que nos primeiros capítulos; a solidão aprofunda-se e salienta-se pelo epíteto чужой (estranho, alheio, dos outros), usado mais de uma vez. No texto original, as frases soam idênticas, reforçando a sensação de tristeza e solidão:

Сижу я один-одинешенек в чужом городе, на чужой кровати...

...сижу в этом маленьком нумере, на этой кровати с чужим, серым одеялом...

но все это не помешает мне умереть на чужой кровати, в тоске, в совершенном одиночестве... ${ }^{59}$

$\mathrm{Na}$ tradução brasileira, com a troca de alheio pelos sinônimos estranho e que não é meu, tal efeito quase todo se perde:

${ }^{59}$ A. Tchékhov, Moscou,1977, p.p.305-306 
Estou sentado sozinho numa cidade estranha, sobre uma cama estranha... (157)

...mas nada disso impedirá de morrer numa cama alheia, angustiado e completamente só...(158)

estou sentado neste pequeno quarto de hotel, sobre esta cama, com um cobertor cinzento que não é meu... (157)

$\mathrm{Na}$ alma da personagem, há um completo vazio; ela é indiferente até ao tempo, que passa devagarinho; ela escuta o bater do relógio, que dá as horas uma após a outra; ela nota o começo da dor na face, mas já nada a toca; ela espera apenas as manifestações da doença e a morte.

O relógio do corredor bate uma hora, depois duas, três...Os meses derradeiros da minha vida, enquanto espero a morte, parecem-me bem mais compridos que toda a minha existência anterior. $E$, antes, eu nunca soube conformar-me como agora com a lentidão do tempo. Outrora, esperando o trem numa estação ou sentado fazendo exame, um quarto hora parecia uma eternidade, mas agora sou capaz de passar a noite inteira imóvel na cama e pensar com absoluta indiferença que, amanha, haverá uma noite igualmente comprida, incolor, e depois de amanhã...

No corredor, betem cinco horas, seis, sete... Sobrevém o escuro. (156)

No trecho sobrecitado, a comparação a um passageiro que espera por um trem faz-nos lembrar a caracterização de Kátia pelo professor no segundo capítulo:

A expressão atual é fria, indiferente, distraída, como a dos passageiros que precisam esperar muito tempo o trem. (124)

Repetem-se, novamente, alguns motivos já encontrados antes. $\mathrm{O}$ estado de insônia leva-nos de volta ao início do primeiro capítulo. Para Nikolai Stepánovitch já não tem importância se é noite ou dia. Para ele, a insônia como tal perde o seu significado principal e as suas coordenadas 
temporais e configuração, uma vez que preenche consigo todo o tempo, propagando-se e distendendo-se em todas as direções. Esse é o único capítulo em que não soa a palavra insônia, como se também ela tivesse perdido o sentido; dão-se somente os seus indícios e sinais característicos:

Noite igualmente comprida, incolor (157)

Quando amanhece, estou sentado na cama, abraçando os joelhos...(158)

O único acontecimento importante de enredo, em toda a novela a fuga de Liza com Hnekker e o seu secreto casamento - permanece "nos bastidores" e sequer é comentado; Nikolai Stepánovitch, que vem a saber disso por um telegrama, assusta-se um instante não com o ocorrido, mas a sua própria indiferença, e profere a si uma sentença:

Dizem que os filósofos e os sábios autênticos são indiferentes. Não é verdade, a indiferença constitui uma paralisia da alma, a morte prematura. (158)

Já não há sentimentos, e ele novamente volta aos seus pensamentos, a todas aquelas mesmas reflexões, à sua "rabugice": a contradição entre o nome famoso e o homem, a filosofia dos estóicos, a mundividência do bárbaro e do escravo, a insatisfação com as más condições etc. $E$, sobre o fundo de tudo isso, é dessas reflexões que vem a conclusão de que a causa do que acontecera, fora a falta duma ideia geral na sua vida.

Como já afirmámos, a "ideia geral" é reconhecida por muitos críticos, tanto da época quanto de hoje, como a ideia principal da novela, mas, como não foi dito concretamente o que se entendia e se entende por tal conceito, as opiniões dos estudiosos chegam a divergir completamente e vêm à baila variantes sociais, ideológicas, filosóficas, religiosas... Há a opinião de que os pensamentos acerca duma "ideia geral" não passam de 
sintoma do estado doentio da personagem (V. Kataev, M.Smirnov, Doljenkov).

Para os dois primeiros, o pensamento acerca duma ideia geral é mais uma "tergiversação" do professor consigo próprio, uma tentativa de salvar-se do que não consegue penetrar. Tchékhov, salientando mais de uma vez o modo "individualizado" de a Medicina encarar cada personalidade humana, simplesmente não podia ter em mente uma ideia concreta, comum a todos.

Nikolai Stepánovitch sentiu a necessidade de algum dogma salvador apenas em face da morte, quando a moléstia já o fizera esquecer a ciência e o trouxera de volta à vida corriqueira do dia a dia. Uma "ideia geral", assim, poderia tornar-se uma justificação da vida passada e propiciar um modo tranquilizador de encarar a morte inelutavelmente cada vez mais próxima. Ele não nota que já experimentara várias posições diante da vida - os maus pensamentos do Araktchéiev e a indiferença - refutando sucessivamente tanto uma como a outra. Para V. Katáev, com isso a personagem é simpática ao leitor. Ideias gerais do tipo "trabalha" ou "conhece-te a ti próprio" também se revelam inaceitáveis para ele, bem como a doutrina populista e o ensinamento tolstoiano lhe são completamente alheios. A filosofia de Marco Aurélio, sob cuja influência o professor estivera durante muitos anos, também deixara de satisfazer-Ihe.

"Conhece-te a ti mesmo" - eis um belo e útil conselho; dá pena, porém, que os antigos não tenham adivinhado como indicar o meio de utilizá-lo. (158)

Também Ihe é alheia a resignação cristã, e "o deus do homem vivo", para ele, não é o deus de Tolstói. Até a Ciência, que antes fora para ele mais importante e essencial do que todas as influências externas, cessara de ser a força salvadora, otimista. E as amarguras, sofrimentos e dúvidas de pessoa viva acabaram por vencê-lo. Com isso se exauria o círculo das "ideias gerais", por que se poderia nortear a personagem de Tchékhov. 
Desse modo, nenhuma "ideia geral", se por isso entendermos uma filosofia ou crença que muna [a pessoa] com um programa de comportamento inconsútil e corresponda, em todas as situações da vida, a elevadas exigências intelectuais e morais, não poderia satisfazer ao professor, tal como pintado por Tchékhov . ${ }^{60}$

Em polêmica com V. Katáev, V. Linkov escreve que os pensamentos de Nikolai Stepánovitch acerca duma "ideia geral" não são sintomáticos, mas da sua essência e não a afastam da sua real situação e, pelo contrário, nascem das profundezas do seu ser e desvelam-lhe a realidade na sua verdadeira tragicidade. Esses não são temas, em que se possa pensar ou não pensar, como, por exemplo, teatro e literatura, mas gerados pela própria vida.

As amarguras e tristezas dos últimos dias de vida levaram Nikolai Stepánovitch a eles. Uma "ideia geral" não é um conceito abstrato e lógico, mas expressão duma profunda experiência da personagem. ${ }^{61}$

Ao citarmos a polêmica acerca dessa questão, salientamos dois aspectos: em primeiro lugar, que Nikolai Stepánovitch menciona colegasfilósofos, quando fala duma ideia geral:

Foi somente pouco antes da morte, no ocaso dos meus dias, que notei em mim a ausência daquilo que os meus colegas filósofos denominam uma idéa geral (161)

Quer dizer, ele tem em mente, apesar de tudo, um conceito lógico e abstrato.

E, em segundo lugar, o modo como ele próprio caracteriza o seu estado naquele instante:

Para me ocupar com pensamentos, coloco-me no meu ponto de

\footnotetext{
${ }^{60}$ V.Kataev

${ }^{61}$ V.LINKOV, Moscou, 1982, p.67-68.
} 
vista anterior, quando não era indifirente a tudo...(157)

Torno a deitar-me e começo a conjeturar sobre os pensamentos com que poderia ocupar-me. Pensar em quê? Parece que já pensei em tudo e que não há nada capaz de suscitar agora o meu pensamento.(158)

Quando amanhece, estou sentado na cama, abraçando os joelhos, e, não tendo o que fazer, procuro conhecer a mim mesmo...

Quando, em outros tempos, dava-me na veneta compreender alguém ou a mim mesmo, eu examinava não ações, em que tudo é convencionado, mas os desejos. Dize-me o que desejas, dir-te-ei quem és.

Também agora, faço um exame a mim mesmo: o que eu quero? (159)

A personagem assume a opinião anterior e por não ter que fazer começa a examinar-se, e chega à conclusão de que, na sua vida, não há algo principal, que seria o mais importante. Essa posição anterior é tãosomente mais uma tentativa de salvar-se com o retorno a vivências conhecidas. A falta de algo de que Nikolai Stepánovitch tem uma vaga sensação, não está no campo das ideias. No nível da consciência duma personagem limitada por ideias rigorosamente científicas acerca da vida, resolver o problema que se lhe apresenta, é impossível; para tal, para além de conhecimentos científicos, exigir-se-ia também experiência humana espiritual.

Se olharmos as inúmeras personagens do mundo tchekhoviano, poderemos notar que todas as dotadas duma mundividência consolidada e variadas "ideias gerais", são tão pouco simpáticas ao escritor e ao leitor, quanto aquelas, cuja singela mundividência consiste no aproveitamento tosco do que a vida lhes possa oferecer, na falta de necessidade de vida espiritual (Hnekker); a posição didática das primeiras frequentemente revela-se ilusória e sempre desagradável - Lida ("A casa de mezanino"), doutor Lvov ("Ivánov"), von Koren ("Duelo") e, em "Uma história enfadonha", Piotr Ignátitch. E isso embora a própria ideia possa ser cara ao escritor, como, por exemplo, a construção de escolas e hospitais para 
pobres, propagandeada por Lida. Já as personagens que procurem, tenham dúvidas, sofram e, principalmente, as que percebam a vida sem nenhuma base ideológica, expressa de forma verbal, são espontâneas, como se nas suas veias circulasse o sangue da natureza, como o diácono e Samóilenko ("Duelo"), Dýmov ("Ventoinha") e Míssius "A casa de mezanino"), e um tanto infantilmente ingénuas e despertam simpatia e interesse. A falta de explicações da parte do autor para o que representaria uma ideia geral, está na indefinição e ilusoriedade da própria existência dela.

E o principal, a nosso ver, é que o pensamento acerca duma ideia geral não é salientado de nenhum modo, nem pelo estilo, nem pelo ritmo, nem pelo léxico, nem por símbolos, e não se encontra, nas posições fortes do texto (início, final e subtítulo), não há os "ganchos' (pretextos), sinais, sugestões e o subtexto, por meio do qual o autor "se manifeste", aguçando a consciência e o subconsciente do leitor para os aspectos que julgue especialmente importantes. O pensamento acerca duma ideia geral, expresso verbalmente, existe no fluxo das reflexões monótonas, "enfadonhas (tediosas!), do professor, que caracterizam só a ele próprio.

A última cena da novela, aparentemente, repete uma situação do quinto capítulo: a personagem encontra-se sozinha, o surgimento inesperado de Kátia, a sua histeria e pedido de ajuda, que lembram a histeria e o pedido de ajuda de Liza, o alheamento e incompreensão, a saída de Kátia e a palavra "adeus". No entanto, fazendo variar uma situação conhecida, o autor apresenta-a por um ângulo de visão completamente novo. Com o surgimento de Kátia, mudam instantaneamente o ritmo e o léxico, levando-nos de volta à "noite de pardais". Em lugar de frouxas reflexões em fluxo lento, lê-se:

\footnotetext{
Apresso-me

surpreso

de repente ela se ergue num arranco

ofegante, o corpo todo trêmulo

Cai sobre uma cadeira e põe-se a soluçar.
} 
Agarrando-me a mão e beijando-a

jogou a cabeça para trás, estrala os dedos, bate os pés implora

No vocabulário desse trecho, há muito movimento, real e figurado, desordenado, caótico, destruidor, e ele é salientado pelos verbos "падать" (cair) е "валиться" (tombar de cansaço; desabar):

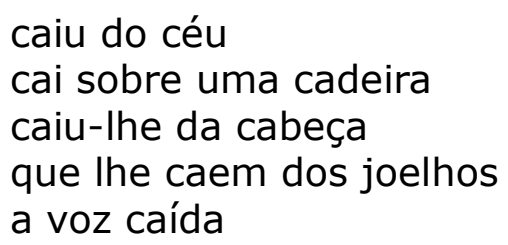

O ritmo é intermitente; no texto, reaparece novamente uma grande quantidade de sinais de interrogação e de exclamação e reticênciaspausas, que tanto mais lembram os procedimentos dramatúrgicos de Tchékhov, e a cena é um diálogo mais parecido a diálogos.

Intensificam-se as pausas, expressas pela reticência e pela palavra "молчание" (silêncio), repetida três vezes em duas páginas.

E da indiferença da personagem não sobra nem vestígio:

Estou perplexo, confuso, comovido por aqueles soluços, e mal me seguro sobre as pernas.(161)

E logo acrescento, a voz caída:

- Em breve, deixarei de existir, Kátia (161)

Kátia não Ihe pede uma ajuda real; ela precisa de palavras:

Ao menos uma palavra, ao menos uma palavra! (161)

Já para ele, as palavras perderam já o seu valor, sentido e utilidade, ele não consegue já dizer hipocrisias. E, em lugar disso, Nikolai Stepánovitch repete duas vezes uma mesma frase: 
Ele como que tenta recuperar a simplicidade de antes, as relações de antes, por meio dum gesto simples, corriqueiro e amigável, o desjejum a dois, que para ele, naquele momento, se torna mais importante do que quaisquer ideias e palavras.

O frio exalado por Kátia, a pessoa mais querida dele e que de repente se tornara uma estranha (чужая), como se se tivesse colocado do lado dessa cidade estranha (чужой) e da cama de estranhos (чужая), é um pormenor muito simbólico.

responde ela com frieza, tendo sorrido com frieza tem a mão fria como que alheia

E podemos voltar ao terceiro capítulo, para sentirmos a trágica diferença existente entre o jantar em família de antes e o desjejum de agora, que não aconteceu:

A seguir, sentamo-nos na saleta aconchegante e começamos a conversar.

A tepidez, o aconchego do ambiente e a presença de uma pessoa simpática. (131)

São paralelos os episódios do final dos capítulos 5 e 6 : incompreensão, alheamento, afastamento de Kátia, o "adeus" não pronunciado da personagem. Mas, se no final do quinto, o afastamento de Kátia era temporário, o "adeus" não era necessário e Nikolai Stepánovitch não tivera tempo de dizê-lo, então agora, no sexto, Kátia afasta-se para sempre e o mudo e não pronunciado "adeus" adquire um profundo significado simbólico de síntese. Kátia vai-se, como vai-se a própria vida, e o professor acompanha-a com os olhos, com a derradeira esperança de que ela olhe para trás ao menos uma vez. E a esperança é desmentida: enterro?" Mas ela não me olha, tem a mão fria, como que 
alheia. Acompanho-a calado até a porta... Ei-la que saiu do meu quarto e caminha pelo corredor comprido, sem olhar para trás. Sabe que a sigo com os olhos, e, provavelmente, voltarse-à na curva.

Não, não se voltou. O seu vestido negro apareceu pela útima vez, não se ouviram mais os seus passos... Adeus, meu tesouro!(162)

Com pormenores simbólicos - os passos de Kátia e o seu vestido - fecha-se o círculo da sua primeira aparição no texto :

eu ouço passos conhecidos, um frufru de vestido, uma voz querida... (117),

até à despedida final dos dois.

O final da novela impressiona pelo seu saturamento emocional e simbólico. O estilo é elevado e contido. Nos minutos mais trágicos e de mais emoção, a mudez das pessoas torna-se a única forma possível de expressão.

Tem-se o mesmo tempo passado dos verbos, mas, tal qual na noite de pardais, eles distendem cada instante, como se num desejo impossível de reter o tempo. $\mathrm{E}$, pela primeira vez, surgem repentinamente verbos do aspecto perfeito no tempo passado, que repetidas vezes reforçam a tragicidade - "не оглянулась" (não se voltou), "мелькнуло" (apareceu pela última vez), "затихли" (não se ouviram) - para sublinharem que esses tão preciosos minutos já pertenciam ao passado.

A última palavra do texto, "сокровище" ("tesouro"), é inesperada no vocabulário da personagem. A sua etimologia remonta ao verbo "скрывать" ("ocultar"). "Сокровище" é algo muito valioso, oculto, guardado. Pelo conteúdo fonético, associa-se com "кровь" ("sangue") movimento, pulsação de vida. E a última frase, a única frase dirigida em pensamento a Kátia, semelhante à "Míssius, onde estás?", frase que fecha o conto "A casa de mezanino"), torna-se também simbólica e de síntese. Nikolai Stepánovitch despede-se não apenas de Kátia: ele despede-se 
também da vida, com o que possuía de valioso e secreto e com o que deixara de enxergar ou perdera, com o que Kátia deixara de enxergar ou perdera.

O mais profundo e complexo não se presta a análise lógica, a reflexões e conclusões; a natureza dessa tragicidade é inexplicável. E a força poética desse final é muito mais demolidora e impressionante do que meditações acerca duma "ideia geral". É precisamente no final que a voz da personagem é mais consonante com a voz do autor.

\subsection{Simbologia}

Antes de passarmos à análise de episódios das recordações, nós nos deteremos brevemente em particularidades da simbologia tchekhoviana e no papel da música na novela.

... o sentido, transferido dum objeto a outro, funde-se a esse segundo objeto de modo tão profundo e multilateral, que se torna já impossível dissociar um do outro. O símbolo, nesse sentido, é a completa interpretação da figuratividade ideológica da coisa com a própria coisa. ${ }^{62}$

Pela primeira vez, falou-se do símbolo em relação a Tchékhov por A. Biélyi, no artigo "Tchékhov" (1907). Escreve ele que, a par da continuação da tradição realista, na base da obra do autor de "Uma história enfadonha" foi "colocada a dinamite do verdadeiro simbolismo"63. Comparando Tchékhov e M. Meterlink, na coletânea de ensaios "Луг зеленый" ("Prado verdejante"), Biélyi observa que os símbolos tchekhovianos são mais sutis, translúcidos e menos premeditados. Eles personificam-se por inteiro no real, integrando-se completamente à vida.

Tal especificidade da simbologia tchekhoviana é estudada por A.

\footnotetext{
${ }^{62}$ Disponível em: (https://unotices.com/book.php?id=32161\&page=11)

${ }^{63}$ A.TCHÉKHOV. Pro et contra, 2002, p.831.
} 
Tchudakov:

... o objeto simbólico de Tchékhov pertence logo a duas esferas, a "real" e a simbólica, e a nenhuma delas em mais alto grau do que à outra. Ele não brilha com uma luz sempre igual, mas cintila, ora com a luz simbólica, ora com a "real"...64

A simbólica artística de Tchékhov existe tanto no sistema mundial quanto no propriamente autoral (tem-se em mente o facto de Tchékhov haver utilizado símbolos universalmente aceitos e criado os seus próprios). Muitas imagens, embora pertençam aos símbolos universais da arte mundial (Lua, Sol, luzes), ao entrarem no mundo artístico dele, adquirem uma especificidade, determinada pela concepção da obra e do olhar do autor. Não raramente, os pormenores-símbolos transitam duma obra a outra ou, então, repetem-se mais de uma vez num texto e, às vezes, existem como imagens isoladas. No conjunto dessas podem incluir-se objetos caseiros ou roupas, animais, aves, a natureza, cheiros, acidentes geográficos, o estado das personagens etc.

Às vezes, os símbolos formam pares de antónimos (quente-frio, úmido-seco, fresco-abafado) ou grupos de coisas de significado próximo (secura, abafo, mediocridade, falta de cultura, pó). Nesse caso, pela interação de diversas figuras semânticas, surgem correspondências figuradas, que as trasnformam em símbolos. Assim, por exemplo, em "Uma história enfadonha", "sapos" são referidos duas vezes e apenas no contexto dum ar "envenenado" pela maledicência.

Em consequência das falas maldosas, o ar torna-se mais denso, mais abafado, envenenado agora pela respiração não de duas rãs, como no inverno, mas de todas as três. (151)

Às vezes, o significado dos símbolos varia ou torna-se o oposto; ocorre, pela definição de P. Doljenkov, o "envelhecimento-apagamento do

${ }^{64}$ A.TCHUDAKÓV. Moscou:"Nauka", 1971. p.172 
signo". Isso manifesta-se especialmente quando a personagem recorre a lembranças. Um exemplo disso podem ser as imagens do jardim e das reuniões à mesa, na comparação do presente e do passado de Nikolai Stepánovitch.

Nós já nos detivemos nos símbolos mais significativos da novela ("tédio" e "insônia'), contudo, o autor usa muitos outros. Sobretudo, devem citar-se figuras/imagens da natureza (céu, Sol, Lua e mar), que estão relacionadas com a infinitude do espaço-tempo, com a liberdade e uma força inexplicável, sobre a qual o homem mortal não tem nenhum poder. Em "Uma história enfadonha", eles estão quase sempre no contexto de pensamentos acerca da morte e introduzem o motivo da predestinação da vida.

Quer o céu esteja coberto de nuvens, quer brilhem nele a lua e as estrelas, sempre olho para ele ao regressar para casa, e penso que em breve a morte há de me levar (141)

A natureza me parece bela como sempre, embora o Demônio me murmure que todos estes abertos e pinheiros, pássaros e nuvens brancas no céu, não notarão a minha ausência daqui a três ou quatro meses, depois que eu morrer. (149)

Em seguida, sigo pelo campo, passando pelo cemitério, que não me causa absolutamente nenhuma impressão, embora em breve eu me deite nele; passo depois por um bosque e atravesso novamente o campo. (143)

Nessa mesma série da simbólica natural, podemos examinar também o motivo do jardim, um dos motivos básicos na obra de Tchékhov. O jardim é o paraíso terrestre, via de regra perdido, arruinado ("O jardim das cerejeiras"), e o seu destino sói tornar-se um protótipo da vida das personagens: a bela floração dura breves instantes, e àquelas resta apenas recordá-los. Ou, então, personifica o conflito entre o corriqueiro da vida e o espiritual, e é assim que se examina o paralelo entre o paraíso terrestre e o celeste na novela "O monge negro"; a perturbação da harmonia entre eles leva à morte da natureza e das pessoas. 
Em "Uma história enfadonha", o jardim do seminário do jovem Nikolai está ligado com as esperanças, os sonhos dourados e o futuro aberto para ele. No tempo presente, quando o professor escreve os seus apontamentos, a figura do jardim, agora já o da universidade, torna-se um mísero arremedo da anterior. No primeiro fragmento composicional, ele é apresentado como uma reunião de arvoretas mirradas e de aspecto desalentador:

E eis o nosso jardim. Parece que não está melhor nem pior que no meu tempo de estudante. Não gosto dele. Seria muito mais intelligente se, em lugar das tuberculosas tílias, das acácias amarelas e dos lilases ralos, aparados, crescessem aqui altos pinheiros e bons carvalhos. (107)

no segundo, apenas como um pequno jardim à frente da casa:

Видны мне зубцы палисадника, сонные тощие деревца у окна. ${ }^{65}$

Vejo o muro ameado do meu jardim, duas ou três arvorezinhas esquálidas. (145)

e no terceiro, quando já não restam nenhumas esperanças, não há referências a nenhum jardim.

A Lua modifica o mundo real e acrescenta-lhe o que é do Além, o eterno, e a ela está ligado não apenas o elemento natural, senão também o elemento da alma humana e as manifestações desta, como o amor, o ódio, o medo e a tristeza (tédio), que frequentemente não têm causa e são existenciais. A Lua reflete algo imaginário, enganador, próximo à morte, e não raramente a sua figura entra em correspondência com a de "cemitério":

Abro a janela e tenho a impressão de estar vendo um sonho: embaixo, apertada contra a parede, está uma mulher de negro, fortemente iluminada pelo luar, e dirige para mim os

${ }^{65}$ A. Tchékhov, Moscou,1977, p.294. 
olhos grandes. Tem o rosto pálido, severo e fantástico devido ao luar, como que de mármore, treme-lhe o queixo.

-Sou eu...- diz ela. - Eu...Kátia!

Ao luar, todos os olhos da mulher parecem grandes e negros, as pessoas, mais altas e mais pálidas, e provavelmente por isso não a reconheci no primeiro instante. (155)

Encontra-se algo semelhante em "Iónytch" e "A gaivota", bem como em muitas outras obras:

Nos primeiros tempos, deixara Startsev estupefato o que ele via agora pela primeira vez e que, provavelmente, não Ihe ocorreria já tornar a ver: um mundo não parecido a nada, um mundo em que era tão bonito e suave o luar, como se aqui fosse o seu berço, onde não havia vida, não e não, mas onde em cada álamo escuro, em cada sepultura, se sentia a presença dum mistério prometedor duma vida serena, bela, eterna. ${ }^{66}$

(O pano sobe, sescortina-se a vista sobre o lago; a lua, no alto do horizonte, se reflete na áqua; sobre uma grande pedra está sentada Nina Zareétchnaia, toda de branco). ${ }^{67}$

Da mesma forma, as figuras da água, do ar fresco, da janela aberta e do oásis simbolizam a salvação, reanimação. Opostos a eles, estão a secura, o abafo, a mediocridade, a falta de cultura, personificação da ausência de talento, do tédio, do desespero e da rotina.

\footnotetext{
A atenção se refrescou, e eu posso continuar (112)

Minha boca se resseca, a voz enrouquece, a cabeça gira...Para ocultar dos alunos o meu estado, a todo momento bebo áqua...(112)

...o meu pobre anfiteatro aparece-me como um oásis cujo riacho secou... (147)

Acendo depressa a luz, tomo áqua diretamente da jarra, depois dirijo-me apressado para a janela aberta. (152)
}

\footnotetext{
${ }^{66}$ A.TCHÉKHOV, Moscou, 1977, p.31.

${ }^{67}$ A.TCHÉKHOV, A Gaivota, Sõ Paulo, 2009, p.16.
} 
É característica do sistema de símbolos de Tchékhov também a recorrência a figuras do mundo animal. Em relação a isso, sobretudo vem à memória a famosa peça "A gaivota". Em "Uma história enfadonha", nos apontamentos, Nikolai Stepánovitch menciona aves e animais apenas especulativamente, se não contarmos um episódio-recordação; eles comparecem somente como símbolos ou soam em provérbios e num nome ou outro, salientando quão distante o professor, que vive no mundo dos seus próprios pensamentos, está da vida natural que o cerca:

o livro "Aquilo sobre o que cantava a andorinha" como se uma abelha me picasse é um cavalo de carga ou, como se diz também, um sábio obtuso

...continuam a picar-me o cérebro, qual mosquitos.

È uma cáfila de selvagens...

Tem olhos esbugalhados, de lagosta, a gravata lembra pescoço de lagosta ...

e sentimentos que não conhecia trançaram seu ninho em minha alma

queixo cavalar

Um enfado terrível, até as moscas morrem.

лисья хитрость (um esperteza vulpina)

As moscas também não conhecem a ciência

...ficam sentados aí como duas rãs e envenenam o ar com a sua respiração?

Esses seus alemães são uns burros...

...a galinha Hnekker seja muito mais intelligente que o professor-águia.

Noite de pardal.

As aves reais, mencionadas no texto, não estão à vista; ouvem-se apenas as suas vozes, sempre ao longe: o canto dum galo, o pio duma coruja, o uivo dum cão.

Já se o canto matinal do galo traz alívio a Nikolai Stepánovitch e assoacia-se a renascimento, esperança:

Passa um longo período de tempo penoso, antes que um galo cante no pátio. E o meu primeiro anunciador de boas novas. (103)

o uivo dum cão e o pio da coruja (mencionados duas vezes no texto), por 
sua vez, são símbolos de pressentimentos funestos e desespero:

Nunca dei importância a tais augúrios como um uivar de cão ou um pio de coruja. (154)

...comece a ver em cada ave uma coruja, e ouça em cada som um uivar de cães. (159)

Alguns dos exemplos supracitados são recorrentes e podem encontrar-se numa série de outras obras.

Assim, na peça "Ivánov", escrita mais ou menos à época de "Uma história enfadonha", Anna Petrovna, que se encontra em estado doentio e de ansiedade, a única dentre todas as personagens, ouve o tempo todo o pio duma coruja.

«Anna Petrovna (tranquilamente). De novo está a piar...

Chábelskii. Quem pia?

Anna Petrovna. Uma coruja. Pia todas as noites" (tradução nossa)

No primeiro ato de "A gaivota", Sórin fala dum cão que uiva e por causa de quem "a irmã não conseuira a noite toda conciliar o sono"; esse pormenor sem significado para o enredo, "casual", intensifica a atmosfera de tensão.

Como símbolo do aconchego familiar, de paz, afinidade e atmosfera amistosa (ou, ao contrário, da falta disso) sóem usar-se coisas do mundo material como casa ("A casa de mezanino", "Minha vida"), mesa, de trabalho ou de refeições, samovar e chá ("Tio Vánia", "As três irmãs", "Três anos"). Em "Uma história enfadonha", a falta de laços entre os membros da família é dada pelo desalentador ambiente dos almoços domésticos, à exceção de dois episódios: a recordação das reuniões familiares à mesa de antes e o ambiente "caloroso' dum jantar na casa de Kátia, no capítulo 3, o qual, no final da novela, torna-se uma recordação, mais um momento perdido/passado da vida. E, quando Nikolai Stepánovitch propõe desjejuarem ("vamos almoçar") a Kátia, na realidade, inconscientemente ele quer restaurar as antigas relações, a "cordialidade" de antes, e dissipar o "alheio" e o "frio", que agora emanam 
da pessoa querida.

Há mais pormenores: Vária, que reprocha a si a memória curta por causa dum samovar esquecido, e o mercador ruivo:

- Por que estou aqui sentada? - diz, erguendo-se. - Faz muito tempo que o samovar está na mesa. Tornei-me tão desmemoriada, meu Deus! (105)

...ali está sentado um comerciante ruivo, um homem muito indiferente, que toma chá de uma chaleira de cobre. (107)

A mesa de trabalho (e a figura dos livros, sempre ligada a ela) permite às personagens retirarem-se para o seu próprio mundo, encontrar a paz e o equilíbrio espiritual. No entanto, no estado em que se encontra Nikolai Stepánovitch, as suas ações tornam-se maquinais e dão o resultado costumeiro; a tentativa permanece inútil, e não se obtém nenhum conforto interior.

Passo uma hora ou duas andando de um canto a outro do quarto e examino quadros e fotografias há muito conhecidos.Quando enjôo de andar, sento-me à mesa (сажусь за свой стол). Permaneço ali imóvel, sem pensar em nada e não sentindo qualquer desejo; se tenho um livro na frente, aproximo-o maquinalmente de mim e leio-o sem qualquer interesse. (103)

Apetrechar um lugar de trabalho no espaço da sua casa para uma dada pessoa, como o faz Kátia, é sinónimo de especial confiança e intimidade.

Acompanha-me a uma saleta muito aconchegante e diz, mostrando uma escrivaninha:

-Isto aqui... Preparei para o senhor. Vai estudar aqui. Venha todos os dias e traga o seu trabalho. Pois lá em sua casa somente o atrapalham. Vai trabalhar aqui? Quer?

Para não magoá-la com uma recusa, respondo-lhe que vou trabalhar em sua casa e que o quarto me agrada muito. A seguir, sentamo-nos na saleta aconchegante e começamos a conversar.

A tepidez, o aconchego do ambiente e a presença de uma pessoa simpática despertam-me agora não mais um sentimento de praser, como outrora...(131) 
Na peça "Tio Vânia", o doutor Ástrov tem uma tal mesa na propriedade dos Voinítskie:

Tenho minha própria mesa nesta casa...no quarto de Ivan Petróvitch. Quando estou totalmente exausto e apático largo tudo, corro para cá e me distraio com esta coisa por algumas horas...Enquanto Ivan Petróvitch e Sofia Aleksándrovna fazem contas com ábaco, fico sentado ao lado deles na mesa, fazendo meus borrões. O ambiente é tão aconchegante e tranquilo - e o grilo canta. ${ }^{68}$

Здесь в доме есть мой собственный стол... В комнате у Ивана Петровича. Когда я утомлюсь совершенно, до полного отупления, то все бросаю и бегу сюда, и вот забавляюсь этой штукой час - другой... Иван Петрович и Софья Александровна щелкают на счетах, а я сижу подле них за своим столом и мажу - и мне тепло, покойно, и сверчок кричит. ${ }^{69}$

É característico que, em ambos os exemplos supracitados, a atmosfera de conforto e paz (уют и покой) é transmitida com auxílio da palavra "тепло" (relacionada com carinho, calorosidade). Deixando os Voinítskie por bom tempo, talvez para sempre, Ástrov fala com tristeza precisamente da mesa, cuja perda associa-se à perda das únicas pessoas caras a ele e do ambiente, em que na alma, apesar da decepção e do tédio, ainda assim brotam a paz e a harmonia:

Faz silêncio. Estala a pena, cantam os grilos. É quente e acolhedor aqui... Não tenho vontade de partir. ${ }^{70}$

A dissipação leviana da herança paterna por Kátia, as numerosas e desnecessárias mesinhas da sua casa e o arrendamento duma datcha com um grande jardim não trazem harmonia e paz à sua vida e são somente uma tentativa de fugir à solidão.

\footnotetext{
${ }^{68}$ A.TCHÉKHOV, O Tio Vânia, Em cartaz, São Paulo, 2009, p.101.

${ }^{69}$ A. TCHÉKHOV, Moscou,1978, p.94.

${ }^{70}$ A.TCHÉKHOV, O Tio Vania, Em cartaz, São Paulo, 2009, p.121.
} 
Os símbolos materiais da mesa, livros, refeição à mesa e chá, que adquirem sinal contrário, ao falarem de desunião e alheamento/estranhamento, estão presentes em cada capítulo, à exceção do quinto, da "noite dos pardais", no qual se dissipa por algum tempo a desunião das personagens, embora não se crie uma verdadeira proximidade.

Há outros objetos que adquirem significado simbólico, como o relógio, os ganchos que caem do cabelo de Kátia, o roupão da personagem etc.

Bem constante, recorrente, no sistema artístico de Tchékhov, é a simbólica das cores, apesar de haver, nesse campo, variações dos significados dos símbolos.

No todo, na novela "Uma história enfadonha", observa-se uma paleta uniforme, acromática: negro, branco, cinzento com algumas incrustações de manchas coloridas.

O cinzento é próximo, pelo significado, das figuras de secura, abafo e tédio e simboliza o desalento, a despersonalização e o "estojamento" da vida.

Tudo é cinzento, medíocre, inflando de pretensão. Uma cidade cinzenta.(162)

E, não por acaso, é precisamente Piotr Ignátievitch, tedioso e limitado, embora de rara capacidade de trabalho, quem recebe epítetos desse tipo:

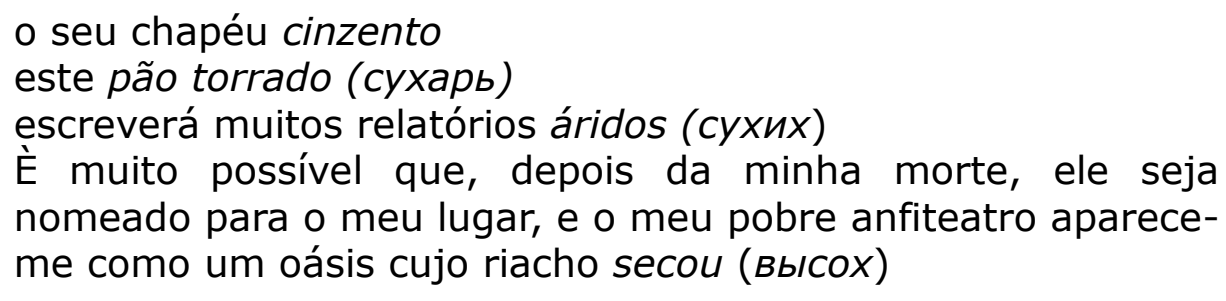
nomeado para o meu lugar, e o meu pobre anfiteatro apareceme como um oásis cujo riacho secou (высох)

Nos três últimos exemplos, o tradutor novamente usa sinónimos, mas o riginal russo traz palavras do mesmo radical: сухой, сухарь e высOX.

A ênfase na cor cinzenta também se faz indiretamente, por meio 
dum léxico criador duma atmosfera de desalento aborrecido:
O portão sombrio
o sombrio dos corredores
a luz insuficiente

Do mesmo modo como a palavra "скука" (tédio), a mais usada do léxico de Tchékhov, esse procedimento é usado pelo autor em muitas e muitas obras. Assim, em "A dama do cachorrinho", a concentração de ociosidade de balneário e desespero é transmitida não só pela marcação cromática "cinzento" (cerca, tapete, coberta, vestido), como também por símbolos semanticamente próximos, como pó e abafo .

$\mathrm{Na}$ descrição do ambiente da casa de Kátia, Nikolai Stepánovitch assinala cores esmaecidas, pálidas e opacas, associadas a preguiça mental e medo à vida, e o temor a cores vivas.

O negro quase sempre simboliza a perda de esperança, da vida que se desperdiça mediocremente, e da falta de futuro. Assim são os olhos de Kátia na "noite dos pardais", bem como a cor do seu vestido. Ela poderia repetir com exatidão as palavras de Macha, ditas no primeiro ato de "A gaivota":

MEDVEDENKO Por que a senhora se veste sempre de preto? MACHA Estou de luto pelo minha vida. Sou infeliz. ${ }^{71}$

Um pormenor interessante: à medida do amesquinhamento da figura demoníaca de Mikhail Fiódorovitch, nos olhos de Kátia, as negras sobrancelhas encanecem (седеют), isto é, vão tornando-se cinzentas (серые).

Quanto ao branco, em algumas situações, ele adquire a figura tanto de pureza, frescor, esperança, florescimento e juventude, quanto da perda de tudo isso ("O jardim de cerejeiras"). Em "Uma história enfadonha", com esse significado, ele aparece somente na figura das nuvens brancas, que

${ }^{71}$ A.TCHÉKHOV, A Gaivota, Em cartaz, São Paulo, 2009, p.7. 
lembram à personagem a vida que passa, e das crianças de cabelos muito claros (беловолосые), que se riem, trepadas numa cerca; em todos os outros casos, o branco tem outro significado: é sinal de esnobismo, pertencimento a determinado meio social.

Apenas uma tradição substiste do infausto passado da medicina: a gravata branca. (110)

.... jantar é agora servido por Jegor, um tipo obtuso e altivo, a mão direita com luva branca.(127)

alimentam-me agora com uma sopa-creme, em que boiam certos caramelos brancas. (127)

Sobre o fundo opaco geral, sobressai "золотой" (dourado), que se encontra mais de uma vez, sempre no contexto do êxito profissional ou da pretensão a tal:

Não podemos deixar de dourar a nossa conversa com chinesices...(114)

(не можем не золотить)

...o meu nome...gravado em letras de ouro sobre a tumba. (160) (золотыми буквами)

A única qualidade de Piótr Ignátievitch, merecedora de respeito, até de admiração da parte de Nikolai Stepánovitch, é a sua laboriosiedade profissional. O epíteto "не человек, а золото" (mais ou menos, vale o seu peso em ouro) soa, em relação a ele, um tanto ironicamente, ressaltando que, fora da sau especialidade, Piotr Ignátievit é um "estojo" vazio (пустой "футляр").

Trabalha da manha à noite, lê tremendamente e lembra tudo muito bem; nesse sentido, não é pessoa, mas ouro em pó (109).

Três cores, negro, branco, dourado, reúnem-se simbolicamente na caracterização duma personagem, o jovem doutorando, pessoa com pretensão a uma brilhante carreira na Ciência, mas, na opinião do professor, pela falta de talento e liberdade de pensamento, incapaz de lográ-la, isto é, destituído de futuro. 
Entra um jovem médico, de terno preto e novo, óculos de ouro, e, naturalmente, gravata branca. (116)

As demais cores são quase indistinguíveis no pano de fundo geral, mas ao olhar atento revelam que a sua inclusão no conjunto da paleta não fora fortuito.

No início do capítulo 4, quando soa otimisticamente "Chega o Verão, e a vida muda" , ficamos a saber que a personagem se instalara num quartinho muito alegre com papel de parede azul claro e distrai-se com livros franceses de capa amarela. Em seguida, novamente se anula a escala cromática, e só no capítulo 5 aparece momentaneamente o chapéu cinzento de Piotr Ignátievitch.

No contexto dum fundo geral opaco da paleta de cores de Tchékhov, os magníficos quadros da natureza, encontrados nos seus contos e novelas, vêm saturados dos mais diversos tons e matizes, da espessura e diafanidade da gama cromática; em "Uma história enfadonha", contudo, não se encontra nada disso (exceção: as nuvens brancas), como se a natureza, para Nikolai Stepánovitch, fosse desprovida de cores. No texto, não há o vermelho expressivo, apenas uma tinta no rosto das personagens nos momentos de confusão e ansiedade e o significado oblíquo do "clarão sinistro" na noite dos pardais; em compensação, aparece duas vezes a cor ruiva, aproximando duas personagens desagradáveis (o mercador ruivo com um samovar cor de cobre, isto é, ruivo, e Hnekker).

Em relação a isso, vem a memória Solomon, da novela "A estepe", ruivo com olhos também ruivos, uma personagem que não agrada ao pequeno Egóruchka.

A cor ruiva, ademais, por si só é viva e está incluída na única e desgraciosa mancha colorida que destoa do tom geral (o retrato de Hnekker), enfatizando a sensação do não pertencimento dessa personagem a todo o mundo professoral, expressa diretamente por Nikolai Stepánovitch. 
É um jovem louro, que não tem mais de trinta anos, de estatura média, muito corpulento, de ombros largos, com suíças ruívas junto às orelhas e bigodinho pintado, que dá ao seu rosto cheio e liso um quê de brinquedo. Veste paletó muito curto, colete colorido e muito estreitos embaixo, e usa sapatos amarelos, sem salto. (125)

Encontrar-se-á algo semelhante mais tarde, em "As três irmãs", em que o cinto verde de Natacha terá precisamente esse significado simbólico.

A simbólica geográfica é uma das mais estáveis no sistema artístico de Tchékhov, e os sentidos figurados de alguns nomes vão de obra em obra (Moscou, Peterburg, Ialta, Khárkov). A ação dos capítulos iniciais de "Uma história enfadonha", sem dúvida, transcorre em Moscou, e nós entendemos isso por características indiretas, como a antiga universidade, os sobrenomes de professores conhecidos e o status da personagem principal; no entanto, não aparece o nome da cidade, uma vez que na composição da novela ela é simplesmente um lugar concreto, no qual a personagem vive e trabalha, à diferença da simbólica Moscou da peça "As três irmãs" - um ponto sagrado, um sonho, ilusório e inatingível.

As numerosas referências geográficas, na novela, tais como os nomes de países, de partes do mundo e cidades, não são símbolos; desempenham, no texto, outro papel, que examinaremos nos capítulos seguintes. E apenas Khárkov, tediosa e cinzenta cidade do desespero e das esperanças desfeitas, é aqui assinalada simbolicamente.

Um dos mais complexos e interessantes símbolos, na base dos quais foi colocada a noção de eterno e momentâneo, de tempo e espaço, de estática e dinâmica, é a mútua combinação figurada de "pontos e linhas" em diferentes contextos. No conto "Luzes" , o entrelaçamento de História passada, guerras antigas e tempo presente realiza-se por meio das figuras de luzes rutilantes e faiscantes e da extensão duma estrada de ferro em construção. Em "Uma história enfadonha", em que o tema principal é o breve instante da vida humana sobre o pano de fundo da infinitude do tempo, essa simbólica também se evidencia na contraposição do breve e cintilante ao longo, extenso, paralisado e fixo, e de manchas a linhas: 
...pulam as manchas claras da sua vela, tremem as nossas sombras compridas...(153).

...прыгают светлые пятна от ее свечи, дрожат наши длинные тени... ${ }^{72}$

No último capítulo, é essa noite, que se arrasta interminavelmente e, por sua vez, se transforma num dia igualmente arrastado, ambos acompanhados pelo bater regular e preciso do relógio, e pelo soar de cada hora.

E, no final, imediatamente após as lágrimas, gritos e movimentos bruscos e a queda de objetos, é o silêncio e o longo corredor, por onde Kátia se vai para sempre.

\subsection{Música}

O tema da música, nas obras de Tchékhov, é inesgotável e foi tratado mais de uma vez por estudiosos da sua literatura, escritores, diretores de teatro e músicos, quase sempre em relação à sua dramaturgia, mas há trabalhos dedicados ao assunto também na sua prosa (I. Eigues, Balabánovitch, Fortunatov, Derman, Gromov). Eles trazem uma análise tanto do papel da música na biografia do escritor, inclusive as suas relações com Tchaikovskii e Rakhmáninov, quanto na sua obra, com um estudo da influência dela no léxico, temática e composição.

No livro Tchékhov e Tchaikóvskii, Balabánovitch assinala os seguintes aspectos da musicalidade da obra literária: linguagem, atenção especial a figuras sonoras, musicalidade da composição, entonação lírica geral. ${ }^{73}$ V. Katáev observa que Tchékhov é um artista-músico e utiliza-se ativamente de procedimentos da composição musical, como repetições e a extensão do tema a várias

\footnotetext{
72 A. TCHÉKHOV, Moscou, 1977, p.302

${ }^{73}$ E. BALABANOVITCH, Moscou, 1973.
} 
vozes-instrumentos ("A complexidade da simplicidade"). Escreve André Maurois:

"Qualquer peça de Tchékhov é igual a uma obra musical. Criase a impressão de que ele tentava levar para o seu teatro a sensação de ternura, leveza vaporosa e beleza melancólica e frágil". ${ }^{74}$

Dmítrii Chostakóvitch considerava que as obras de Tchékhov eram criadas segundo as leis da Música; assim, por exemplo, a estrutura de "O monge negro" é de sonata. O compositor assinalou, no conto, o introito (abertura), a exposição com a parte principal e as secundárias, o desenvolvimento etc. Não raramente, foi apontada a semelhança com Tchaikóvskii.

"A sua peça é abstrata, qual sinfonia de Tchaikóvskii. E o diretor deve apreendê-la antes de tudo com o ouvido". ${ }^{75}$

- escreveu Meierkhold a Tchékhov.

Páginas dos contos e peças de Tchékhov estão literalmente saturadas de nomes de instrumentos, géneros e obras musicais, bem como de compositores e cantores. A temática musical não raramente aparece nos títulos ("Contrabaixo e flauta", "Romance com um contrabaixo", "Pífaro", "O violino de Rotschild"). As personagens cantam, tocam piano, violino, violoncelo, violão e harpa, soam sinos, pífaros solitários e grandes orquestras. Freqüentemente, os sons (por exemplo, o som duma corda rompida em "O jardim de cerejeiras") ou instrumentos musicais tornam-se símbolos e a música não apenas cria uma atmosfera, deixando

\footnotetext{
${ }^{74}$ disponivel em:http://lib.ru/MORUA/portrait.txt

${ }^{75}$ V. MEERKHOLD, Moscou:"Iskusstvo" 1968.
} 
tensas as emoções das personagens e do leitor, senão também avança paralelamente à ação, enriquecendo a obra com um significado complementar ("As três irmãs", "O violino de Rotschild", "Iónitch", "Relato dum desconhecido" e outras).

L. Gromov considera que a musicalidade do escritor é, antes de tudo, a maneira artística de representar a realidade e a vida com os seus lados "maior" e "menor"; ele também assinala a ligação da musicalidade com a composição da obra literária, se todos os componentes ideológicos estão em harmonia com a figuratividade e a estilística e em plena concordância com a ideia do autor.

$\mathrm{Na}$ vida do próprio Tchékhov, desde a infância, a Música ocupara lugar importante; o pai tocava violino, ele e os irmãos cantavam em coro de igreja, e em casa o piano soava constantemente e organizavam-se saraus musicais. A música não o acompanhara simplesmente durante toda a vida: ela foi para ele inspiração, a mais alta manifestação do espírito e, às vezes, até a força dotada da maior capacidade de representação e transmissão dos mais profundos elementos felizes ou trágicos, em comparação com a linguagem.

Naquela petrificação geral, na postura da mãe, na indiferença do semblante do medico, havia algo atraente, comovedor, aquela beleza sutil, apenas perceptível, da aflição humana, 'que ainda se tardará a compreender e descrever e que somente a música, ao que parece, sabe transmitir. (Inimigos) ${ }^{76}$

Sabe-se que Tchékhov conhecia muitos compositores, mas o seu preferido era invariavelmente P. Tchaikóvskii, cuja música ele escutava ainda em Taganrog.

Em 1887, deparou-se ao compositor um jornal com o conto "Миряне" (cujo título seria mudado, mais tarde, para "Письмо" - "Carta"). O conto

${ }^{76}$ A.TCHÉKHOV A Dama do cachorinho, Editora 34, 1999, p.189 
agradou-Ihe tanto, que foi lido duas vezes seguidas, e Tchaikóvskii, sob a sua forte impressão, enviou a Tchékhov uma carta entusiástica, que, infelizmente, não chegou ao destinatário. O encontro pessoal dos dois ocorreu em Dezembro de 1888 em Peterburgo, na casa do compositor Modest Iliitch.

Foi precisamente ali que a Tchékhov ocorreu a ideia de dedicar o seu novo livro ao compositor. Na primavera de 1890, saiu a coletânea de contos «Хмурые люди» ("Gente Carrancuda"), na qual "Uma história enfadonha" ocupa o lugar central. Aberto o livro, o leitor viu na primeira página as palavras "Dedicado a Piotr Iliitch Tchaikovskii". As circunstâncias impediram o músico de responder-Ihe imediatamente, mas, pouco mais tarde, em 1891, ele escreveria do seu grande orgulho da dedicatória. Durante algum tempo, eles planejaram um trabalho conjunto, em que Tchékhov deveria escrever um libreto para uma futura ópera de Tchaikóvskii, "Bella", baseado em motivos de "Um herói do nosso tempo", de Liérmontov, mas os planos estavam fadados a não realizarem-se. No exemplar presenteado ao compositor, este assinalou um trecho, que o encantara com as suas imagens sonoras (conto "Почта" - "Correio"):

Колокольчик что-то прозвякал бубенчикам, бубенчики ласково ответили ему. Тарантас взвизгнул, тронулся, колокольчик заплакал, бубенчики засмеялись. ${ }^{77}$

A sineta retiniu algo aos guizos, e os guizos responderam a ele carinhosamente. A caleça soltou um guincho, moveu-se, a sineta chorou, e os guizos riram-se. (tradução nossa)

A própria dedicatória da coletânea ao compositor já nos obriga a olhar mais detidamente para o subtexto musical dos contos nela incluídos.

Os pesquisadores quase não se dedicaram ao estudo do tema da música na novela "Uma história enfadonha". Citaremos apenas um trecho do livro de P. Gromov. Não se pode concordar com tudo o que está ali exposto, mas o autor assinalou os dois aspectos mais importantes, a nosso ver: em primeiro lugar, ao ter definido o termo musical

\footnotetext{
${ }^{77}$ disponivel em:http://dslov.ru/txt/pe1/tpe1_346.htm
} 
"contraponto", que soa no texto, como um conceito genérico, simbólico o conflito de contradições na vida da personagem (inclusivamente "o meu nome e eu"), - e, em segundo, na opinião dele, Brahms, citado duas vezes, alude a que Tchékhov, na novela, mais precisamente no seu final, criou o seu réquiem, estando sob a impressão dos réquiens do compositor. Indubitavelmente, podemos dizer que o princípio musical se reflete, no todo, na própria composição de "Uma história enfadonha" - no ritmo, estilo, na melodia da linguagem, na especial atenção às imagens sonoras, no conjunto de sons, na criação das figuras das personagens, na sua caracterização e na atmosfera lírica de alguns fragmentos, - e elementos desse princípio musical tornam-se os mesmos sinais que agem no subconsciente e intuição do leitor, isto é, criam o subtexto da obra.

Duas linhas, que soam alternadamente - o tempo presente, o "modo menor" (tema da morte) e as recordações, o "modo maior" (tema da vida) - e se cruzam no relato da vida de Kátia; as inúmeras repetições e retornos de situações, diálogos e imagens, interpretados de modo novo a cada vez; a culminação, a tensão emocional máxima na "noite dos pardais", o capítulo final, no qual se concentram os motivos de todo o texto precedente, o último acorde, que é o trágico final; a mudança de ritmo, ora mais lento, ora mais rápido; o contraste entre silêncio e sons passos, o riscar de fósforos, batidas de relógio, objetos que caem, pausas, o fremir das emoções e o léxico correspondente - ou seja, o que analisámos nos capítulos precedentes do nosso trabalho, tudo isso é que produz a estrutura musical da novela.

Para além da própria construção, os elementos musicais estão presentes também em outros níveis; a menção à Música torna-se meio de representação e encontra reflexo no léxico usado em sentido próprio e em sentido figurado na forma de imagens, epítetos e comparações.

O pescoço, a exemplo de uma heroína de Turguiênev, parece um braço de contrabaixo... (102)

os defeitos da minha voz, que é seca, abrupta e cantante como a de um beato (102) 
...entra a minha Lisa e carregando notas de música, pronta para ir ao conservatório (105)

... a Patti podia cantar-Ihe bem junto ao ouvido (109)

Ela não descrevia, mas cantava o Volga, a natureza...(121)

..as atrizes dramáticas rebaixavam-se a entoar canções de bulevar; os

trágicos cantavam quadras... (122)

Estamos cantando óperas diferentes. (122)

diz com um baixo aveludado(135) (бархатным басом)

É uma canção que já foi cantada. (137)

...baixando a voz toda uma oitava. (156)

Em alguns casos, na tradução, o léxico musical é substituído por sinónimos; assim, por exemplo, a frase "давайте сначала споемся относительно того, что такое диссертация" ("vamos, para começo, afinar-nos em relação ao que é uma tese de doutorado") aparece como "vamos acertar os relógios sobre o que é uma tese".

A atitude em relação à Música torna-se importante meio de caracterização das personagens. E a formalidade profissional de Liza (o tema da conversa repete-se a cada vez e versa sobre os aspectos técnicos da execução e grandes nomes), a falsa e grave praticidade de Hnekker, a mal oculta incompreensão dela por parte da sua esposa Vária e o desprezo de Piotr Ignátievitch a ela iluminam vivamente, qual facho de luz, as qualidades básicas dessas pessoas, ressaltando-as, e, com outros pormenores, permitem a criação de figuras integrais.

As moças e Hnekker falam de fugas, contrapontos, cantores e pianistas, de Bach e Brahms, e minha mulher, temerosa de que suspeitem nela ignorância musical, sorri-lhes com simpatia, murmurando: "Isso é encantador...Será possível? Diga-me..." (128)

Se Hnekker e Lisa iniciam em sua presença uma conversa sobre fugas e contrapontos, sobre Brahms e Bach, ele baixa modestamente os olhos e fica encabulado; envergonha-se de 
que se fale de tais vulgaridades na presença de gente tão séria como eu e ele. (146)

Não toca nem canta, mas tem não sei que relação com música e canto, vende em alguma parte pianos de não sei quem, frequenta muito o conservatório, conhece todas as celebridades e dá ordens nos concertos; emite juízos sobre música, com grande autoridade, e, eu notei, os demais concordam com ele de bom grado... Não sou músico e talvez me engane em relação a Hnekker, que ademais conheço pouco. Mas parecem-me demasiado suspeitas a autoridade e aquela dignidade com que ele fica parado junto ao piano de cauda, escutando, quando alguém toca ou canta (126)

$\mathrm{E}$, do mesmo modo como símbolos e alguns temas, a relação do professor com a Música e a sua apreensão dela podem ir dum oposto ao outro, a depender de a menção a ela estar nas recordações ou no tempo presente dos apontamentos. Assim, os sinos e a harmónica [sanfona], no jardim do seminário, e a figura do maestro, na recordação da leitura duma conferência, tudo isso é a personificação da felicidade, da esperança, do êxito e da inspiração:

$O$ vento trazia de algum botequim distante o rechinar de uma sanfona e uma canção, ou então uma tróica com guizos passava a toda velocidade junto ao muro do seminário, e isso já bastava inteiramente para que um sentimento de felicidade me enchesse de súbito não só o peito, mas até o estômago, as pernas, os braços...(134)

Um bom regente de orquestra, ao transmitir o pensamento do compositor, executa simultaneamente vinte tarefas: lê a partitura, agita a batuta, observa o cantor, faz um movimento ora na direção do bombo, ora do corne-inglês etc. O mesmo faço eu, dando aula. (111)

Nas cenas, em que a personagem principal se encontra sob o poder duma música real, como no jardim do seminário, ou naqueles em que, sob a forma duma comparação emocional, como aquando duma conferência dada por ela, surgem, de modo correspondente, a natureza real e uma viva imagem sua (o mar), a liberdade, a 
infinitude do tempo (o futuro do jovem seminarista) e o poder sobre ele (o talento de conferencista). Ademais, nessas mesmas cenas, os sentimentos e pensamentos são transmitidos por meio dum léxico relacionado também com outros tipos de arte, como se o mundo circundante desabrochasse e se tornasse vasto e multifacetado. Assim, o tema da música acopla-se ao tema do tempo-espaço.

Ouvia a sanfona ou os guizos cujo som se perdia, e imaginavame já médico, esboçava quadros, um melhor que o outro. (134) (no original: pintava quadros)

...sendo então necessário vigiar com muita perspicácia para que os pensamentos se transmitam não na medida do seu acúmulo, mas numa ordem determinada, indispensável à correta composição do quadro que eu quero pintar. Em seguida, procuro fazer com que o meu discurso tenha estilo literário... (112)

Já no presente, Nikolai Stepánovitch não sente necessidade de música e foram-se as emoções e as esperanças, que ela suscitava:

...há música sem qualquer necessidade... (119)

E um pormenor amargamente irónico: a harmónica, que tanto o inspirava antes, agora lembra-Ihe o desagradável riso de Kátia:

Kátia ouvi e ri. Tem um gargalhar estranho: a inspiração alternase rápida, rítmica e exatamente com expiração: parece tocar sanfona, e, nessas ocasiões, em seu rosto apenas as narinas dão risada. (140)

A pesar da perda da sensibilidade musical, Nikolai Stepánovitch preservara-a para os sons e percebe muitas coisas precisamente por meio deles: passos, toques de sineta, batidas de relógio, tosse, o ruge-ruge de vestidos, pios de coruja, uivos de cão etc. Pode dizerse que a sua percepção acústica é significativamente mais rica do 
que a visual; nós já assinalámos que praticamente não há tintas no seu mundo, ao passo que os sons ainda permanecem para ele como um elo com a vida de rápida fuga e constituem um sinal de que ele ainda está vivo:

Gosto de prestar atenção aos sons. A dois quartos de mim, a minha filha Lisa profere algo rapidamente, delirando, minha mulher atravessa a sala de vela na mão e invariavelmente deixa cair uma caixa de fósforos, range um armário ressecado ou inesperadamente o pavio da lamparina passa a zunir - e todos esses sons por alguma razão me perturbam. (103)

E, no último capítulo, quando Nikolai Stepánovitch está completamente esvaziado, indiferente a tudo, quando o tempo se esvai gota a gota e o espaço se retrai até à solidão num desconfortável quarto alheio, de hotel, parece que tudo se enche de batidas de relógio, as quais, preponderantes, vem para o primeiro plano, personificando a vitória do tempo sobre o homem.

Não apenas nas cenas de "modo maior", que já assinalámos nas recordações do professor, senão também nas de "modo menor", em que o "eterno", mais do que a qualquer outra coisa, se aproxima do efémero e final, também aumenta a musicalidade do ritmo:

Quer o céu esteja coberto de nuvens, quer brilhem nele a lua e as estrelas, sempre olho para ele ao regressar para casa, e penso que em breve a morte há de me levar. (141).

E, certamente, em relação a isso, é impossível não lembrar as últimas linhas:

Não, não se voltou. O seu vestido negro apareceu pela última vez, não se ouviram mais os seus passos... Adeus, meu tesouro! $(162)$ 
O aumento da carga musical, em alguns episódios, indica que o germe da ideia do autor, o sentimento tchekhoviano da vida, deve ser buscado precisamente nessa esfera emocional, inspirada ou trágica, na esfera do inexplicável, intuitivo e sujeito às leis gerais da natureza, do tempo e da História e não no campo de reflexões abstratas especulativa.

\subsection{A composição das recordações}

Ele tem um belo passado, como a maioria dos russos cultos. Não há ou quase não há fidalgo russo ou pessoa com formação universitária que não se gabe do seu passado. O presente é sempre pior do que o passado. ${ }^{78}$

As recordações das personagens são significativo elemento estrutural, e a sua introdução no texto constitui um importantíssimo procedimento composicional da poética de Tchékhov. Elas estão presentes em muitas das suas obras, principalmente da fase mais tardia; elas são a lembrança dos anos idos, de acontecimentos, da infância e do "paraíso perdido". Na sua análise, é necessário considerar que, refratando-se na memória da pessoa, os acontecimentos reais deturpam-se, alteram-se. Para a grande maioria das personagens tchekhovianas, o passado é sempre melhor do que o presente, e é precisamente nele que elas procuram pelo que não encontram na rotina diária.

Quase todos os fragmentos dedicados ao passado estão semanticamente contrapostos ao texto dos apontamentos por meio da antítese estabelecida do "antes-agora", vale dizer, estão contrapostos pelo ritmo, pelo léxico escolhido e pelo significado dos símbolos escolhidos e de alguns temas, como a música e os animais. A exceção é o relato da vida de Kátia, cronologicamente mais tardio, isto é, aproximado do tempo presente corrente.

78 SUVÓRIN, 30.12.1888

disponivel em: https://royallib.com/read/chehov_anton/tom_21_pisma_1888_1889.html\#348160 
No texto da novela estudada por nós, há tanto recordações breves quanto outras mais minuciosas, as recordações-relatos. Partindo das sugestões (подсказки), dadas na forma de referências a datas de acontecimentos históricos e a este ou aquele prazo na vida da personagem com números concretos, pode reconstituir-se com bastante completude a biografia do professor. Nessa tentativa, verificámos que, se extraídas as recordações, caoticamente dispersas pelo texto dos apontamentos, e colocadas em sequência cronológica, surgirá um quadro expandido da vida de Nikolai Stepánovitch nas suas etapas principais, mas por pormenores insignificantes e quase invisíveis acompanha-se a cadeia das mudanças psicológicas da personagem, até à constituição do caráter, que observamos nas suas notas, isto é, no último período da sua existência.

No texto, há uma referência à morte de Skóbelev (que faleceu em 1882), e, a julgar pelo facto de que a própria referência se apresenta no contexto do acontecimento lembrado, isso ocorrera havia algum tempo antes. Ademais, o professor Kaviélin, jurista e catedrático da Universidade de Moscou e da Universidade de Peterburgo, cujo nome ombreia com os de Pirogov e Nekrássov, falecidos antes de 1882, é citado como a pessoa com quem a personagem mantivera laços de amizade no passado, e ele próprio morreu em 1885. O poeta N. Nekrássov morreu em 1877; o cirurgião N. Pirogov faleceu em 1881. Por isso, é possível supor que o tempo da ação da novela esteja maximamente aproximado do tempo da sua escrita: entre 1885 e 1889. Nikolai Stepánovitch, aquando da escrita dos seus apontamentos, tinha 62 anos. Consequentemente, nascera entre 1823 e 1827, isto é, na metade dos anos 20 daquele século.

Cronologicamente, a recordação mais recuada no tempo é acerca dum medo infantil no capítulo 4:

$\mathrm{Na}$ infância e juventude, tive por alguma razão medo dos porteiros e criados de teatro em geral, e esse medo conservou-se em mim até hoje. Mesmo agora, eu os temo. Dizem que nos parece terrível somente 0 que não se 
compreende. (144)

Essa observação, feita de passagem, pode vir à lembrança do leitor no capítulo 5 ("noite de pardais"), em que o adulto prova o mesmo pânico ante o incompreensível.

O advérbio непонятно (incompreensivelmente) une-se semanticamente ao conceito de страшно (é terrível). Tal fórmula encontra-se mais de uma vez em variados contextos de obras de Tchékhov. Assim, no conto "Medos", lê-se:
"Tolice! - dizia eu comigo. - Esse acontecimento é terrível somente por ser incompreensível... Tudo o que é incompreensível é misterioso e, por isso, terrível". (tradução nossa $)^{79}$

Em outro, de título parecido, "Medo":

É terrível o que é incompreensível.(tradução nossa) ${ }^{80}$

Em "A casa de mezanino", Míssius pergunta ao pintor:

Mas você não sente medo do que lhe é incompreensível?(tradução nossa) ${ }^{81}$

A morte, a cada vez mais próxima, priva a vida da personagem dos seus contornos costumeiros, torna-a desconhecida, inconstante e incompreensível, e o medo de Nikolai Stepánovitch, no período de escrita dos apontamentos, adensa-se e concentra-se até ao extremo. As causas desse sentimento podem ser reais, como a doença mortal, mas também irracionais, destituídos duma base definida e explicável. Tal sentimento,

\footnotetext{
${ }^{79}$ A.TCHÉKHOV, Moscou,1976, p.188.

${ }^{80}$ A.TCHÉKHOV, Moscou, 1977, p.130.

${ }^{81}$ A.TCHÉKHOV, Moscou,1977, p.180.
} 
ademais, tem um efeito contagioso e é capaz de comunicar-se duma pessoa a outra, o que ocorre na "noite dos pardais".

Desse modo, uma recordação brevezinha acerca dum medo infantil reflete o mesmo problema psicológico, que enfrenta uma pessoa adulta num período dificílimo da sua vida.

A referência seguinte (em ordem cronológica) ao passado é o relato do professor a Kátia acerca do seu período de estudos num seminário. 0 jovem seminarista, desejoso de ingressar na universidade, devia ter 17 ou 18 anos, o que coloca o episódio entre 1840 e 1844.

Depois que me queixei, vem-me uma vontade de dar largas a uma outra das minhas fraquezas senis: as reminiscências. Falo a Káttia do meu passado, e, para minha grande surpresa, comunico-lhe pormenores tais que nem suspeitava existirem íntegros na minha memória. Ela me ouve comovida, orgulhosa, a respiração suspensa. Gosto particularmente de contar-lhe como estudei num seminário e como então sonhava ingressar na universidade.

- Acontecia-me ficar passeando no jardim do nosso seminário...conto-Ihe. _O vento trazia de algum botequim distante o rechinar de uma sanfona e uma canção, ou então uma tróica com guizos passava a toda velocidade junto ao muro do seminário, e isso já bastava inteiramente para que um sentimento de felicidade me enchesse de súbito não só o peito, mas até o estômago, as pernas, as braços... Ouvia a sanfona ou os guizos cujo som se perdia, e imaginava-me já medico, esboçava quadros, um melhor que o outro. (134)

A começar já da primeira frase acerca das "minúcias" (no início dos apontamentos, ele queixa-se da memória), é lembrada a caracterização, feita por ele de Nikolai, porteiro da universidade:

Somente quem ama, pode lembrar assim. (108)

Nikolai Stepánovitch rememora não um acontecimento, uma ação ou atitude, mas uma sua sensação, estado de alma. Estilisticamente, esse episódio relaciona-se com outros dois - um deles está no contexto das recordações: a leitura de conferências; o outro, no final da novela.

O trecho citado, pertencente ao capítulo 3, lembra a melodiosidade dos contos maravilhosos e bylinas russos. A melodiosidade e inspiração 
dessa recordação contrasta enormemente com o ritmo do texto anterior e do posterior dos apontamentos, como se as suas palavras fossem pronunciadas por um poeta ou narrador de lendas, não por um cientista, mais afeito ao estilo dos artigos científicos, e moribundo atormentado por medos, doença e dúvidas.

Ao leitor apresenta-se uma figura, criada pela imaginação da personagem e remetida ao passado, uma figura ideal: sadia, talentosa, dotada dum objetivo na vida, sonhadora, impressionável, cheia das mais luminosas esperanças e, por fim, um jovem absolutamente feliz. Em todo o caso, é assim que o professor se recorda, e também assim o percebe Kátia. De que falta duma ideia geral pode falar-se aqui? A existência do jovem Nikolai é genuína e harmoniosa; a sensação de felicidade preencheIhe não apenas a alma, senão também o corpo. A felicidade é expressão dessa harmonia interior e da co-participação em tudo o que o cerca, e ela surge naturalmente, dos passeios pelo jardim do seminário e dos sons de música que lhe chegam aos ouvidos. A personagem está no limiar duma vida longa e admirável, na qual se realizarão os mais dourados sonhos. No trecho, muda não apenas o ritmo, mas também o significado de elementos simbólicos, como o jardim e a música. O primeiro, aqui, na lembrança, à diferença do jardim e do jardinzinho à frente da casa nas páginas do texto restante, é a encarnação da juventude, do sonho, da vida em flor e das esperanças; a música, por sua vez, liga os sonhos reais do jovem com a futura profissão a algo elevado, espiritual e transcendental. Tem-se a sensação geral da harmonia duma pessoa, da sua alma e do seu corpo com as forças superiores da natureza.

Mais um pormenor interessante nesse trecho: a reação de Kátia. Semelhante reação da personagem adulta decepcionada, nós não tornamos a encontrar, a não ser "a expressão de confiança, havia muito esquecida" ("давно забытого выражения доверчивости") no seu rosto numa "noite dos pardais". 
Do que vem a seguir, ficamos a saber que Nikolai Stepánovitch, realizando o seu sonho, ingressa na Faculdade de Medicina da universidade. O período do seu estudo cai, aproximadamente, na segunda metade do decênio de 1840.

Por censurar os "seus" estudantes:

Deixam-se influenciar facilmente pelos escritores mais recentes, mesmo de segunda classe, mas não são de todo indiferentes a clássicos como Shakespeare, Marco Aurélio, Epícteto ou Pascal, e nessa incapacidade de distinguir o grande do pequeno é que se manifesta mais que tudo a sua falta de espírito prático. (139)

podemos supor que ele próprio se entusiasmara com tais autores, no seu tempo de estudante. E, em seguida, construíra a sua vida, seguindo princípios tão oportunos e convenientes a ele também quando era um jovem médico e quando se tornara um cientista mundialmente famoso. 0 estoicismo, no transcurso de toda a vida, foi a sua ideia geral "feita em pedaços".

Com alguns pormenores completa-se o retrato anterior. $\mathrm{O}$ jovem estudante fuma, gosta de frequentar o teatro e sonha com uma futura fama:

Um judeuzinho, que me vendia fiado cigarros (107)

Na mocidade, eu frequentara muitos vezes o teatro (119)

Parece-me ridícula a ingenuidade com que, quando moço, eu exagerava a importância da fama e da condição excepcional de que desfrutariam as celebridades. (157)

O episódio-recordação seguinte apresenta o jovem cientista modesto no período de escrita da sua tese de doutoramento. Assim, ele situa-se no tempo subsequente à conclusão da universidade, mas anterior ao seu êxito profissional e fama, aproximadamente, na metade dos anos 50. O caminho é-Ihe conhecido havia já três decênios, o que significa que a personagem tem cerca de 30 anos. É quando ele apaixona-se pela 
"fininha Vária".

Ai está o casarão cinzento com uma farmácia; ai existia outrora uma casinhola, onde havia uma cervejaria; nessa, eu ficava pensando em minha tese e foi ali que escrevi a prímeira carta de amor a Vária. Escrevi-a a lápis, numa folha com cabeçalho "Historia morbi. " (106)

Aquela mesma Vária fininha, que eu amei apoixonadamente pela sua inteligência lúcida e boa, pela alma pura, pela beleza e, como Otelo a Desdêmona, pela "compaixão" em relação à minha ciência?Será est`a minha esposa, a minha Vária, que um dia deu à luz o meu filho? (104)

O léxico desses fragmentos transborda a ternura e a ternura e o orgulho não apenas dum pai apaixonado, mas também jovem, ao nascimento dum filho, o mesmo que é citado uma única vez, no contexto da falta de dinheiro, e suscita a Nikolai Stepánovitch, apesar duma longa separação, somente descontenta-mento e irritação. Sente-se que as recordações são caras ao narrrador, contudo, há alguns pormenores indicadores de que, para além de amor, na vida da personagem existe, e desenvolve-se, outra paixão: a ciência.

escrevi a prímeira carta de amor a Vária. Escrevi-a a lápis, numa folha com cabeçalho "Historia morbi"

...amei apoixonadamente... pela "compaixão" em relação à minha ciência. (104)

Ao período seguinte, que abrange as esferas mais importantes da vida da personagem, quando os sonhos do jovem seminarista já se realizaram por completo, é destinada a maior quantidade de recordações com factos e pormenores circunstanciados e episódicos acerca da sua família, amigos, costumes e trabalho:

os meus sonhos se realizaram. Recebi mais do que ousara sonhar. Durante trinta anos, fui um professor amado, tive colegas exelentes, desfrutei uma fama honrosa. Amei, casei-me por paixão, tive filhos. Numa palavra, se olharmos para trás, toda a minha vida me aparece como uma composição bonita, talentosamente 
executada. (134)

O tempo desses acontecimentos situa-se, aproximadamente, nos anos 60. Por volta desse período, ele já está num matrimônio feliz, com um filho em crescimento. À essa mesma época, a meio do decênio de 60, nasce-lhe a filha Liza (está com 22 anos) e, um pouco mais tarde, 18 anos antes da escrita dos apontamentos (fim dos anos 60), ele adota Kátia, de sete anos então. As suas recordações das pequenas Kátia e Liza exalam ternura e enternecimento:

Em criança, gostava muito de sorvete, e eu tinha que levá-la com frequência à confeitaria. O sorvete contituìa para ela a medida de tudo o que era belo. Se queria elogiar-me, dizia: "Você é de creme, papai". Chamava um dedinho de pistashe, outro de creme, o terceiro de framboesa, etc. Geralmente, quando ela vinha de manhã dizer-me bom-dia, eu sentava-a nos meus joelhos e, beijando-Ihe os dedinhos, dizia:

- De creme...de pistache...de limão...(105)

No dia a dia desinteressante e tedioso irrompe essa breve e viva recordação, que reproduz o fresco e doce friozinho (холодок) do gelado (no português europeu; no Brasil: sorvete) ${ }^{82}$, uma sonora vozinha infantil e dedinhos de criança.

A corriqueirice, simbolicamente expressa pela paleta negro-brancocinzenta, como que floresce com cores variadas e alegres, de creme, pistache e limão... O jogo de "dedinhos-gelado/sorvete" proporciona grande prazer a ambos, tendo-se tornado uma tradição diária e permitindo a expressão do seu mútuo e sincero amor, até tornar-se o seu oposto, quando a tradição permanece "por um velho hábito" e os sentimentos já se esvaíram. Nikolai Stepánovitch começa a sentir a falsidade dessa brincadeira de fim protelado. Se, antes, ele "dizia" ternamente, agora ele "murmura, e o frio, mais um pormenor simbólico, lembrador do outrora doce friozinho do gelado/sorvete, no momento

\footnotetext{
${ }^{82} \mathrm{~A}$ palavra russa para sorvete, "мороженное" (morójennoie), provém de "мороз" (moróz), que é о frio de temperaturas muito baixas, "de gelar".
} 
presente torna-se sinal de alheamento e vergonha.

Estou frio como sorvete e tenho vergonha(106)

A pequena Kátia, que ficara sem os pais e fora adotada pela família de Nikolai Stepánovitch, é um ser doentio mas muito confiante e curioso, suscita ao professor carinho, admiração e pena:

A primeira coisa que lembro e amo nessas recordações é a confiança extraordinária com que entrou em minha casa, com que se deixava tratar pelo médicos, e que sempre luzia em seu rostinho. Acontecia ficar sentada em algum canto, a face com um pano amarrado, invariavelmente olhando algo com atenção; se me via então escrever e folhear livros, a minha mulher afanar-se, a cozinheira limpar batata na cozinha ou cachorr brincando, os seus olhos expressavam sempre o mesmo: "Tudo o que se faz neste mundo é belo e inteligente".

Era curiosa e gostava muito de conversar comigo. Acontecia ficar sentada à mesa, na minha frente, acompanhar os meus movimentos e fazer-me perguntas. Interessava-se pelo que eu lia, que fazia na universidade, se não tinha medo de cadáveres, onde ia parar o meu ordenado...

Achava graça em que os estudantes brigassem e eu os mandasse ficar de joelhos, e ria. Era uma criança dócil, paciente, bondosa. Não raro, eu tinnha que ver como lhe tiveram algo, como castigavam sem motivo ou não satisfaziam a sua curiosidade; nessas ocasiões, a constante expressão de confiança era acrescida em seu rosto de tristeza, mais nada. Eu nada sabia interceder por ela; apenas, ao ver aquela tristeza, vinha-me uma vontade de atraí-la para mim, e compadecer-me dela num tom de velha babá: "Minha órfã querida!" (118)

Quaisquer crianças que se encontrem em numerosos contos de Tchékhov, felizes e desditosas, bondosas e más, apresentam uma característica comum e muito importante para o autor: a sinceridade, a falta de hipocrisia e de camadas superpostas de reflexões, dúvidas e ideias adultas. Elas estão em harmonia com o (sistema do) universo, como a próprua natureza, e é-Ihes inata uma sabedoria natural em estado puro:

Дети святы и чисты. Даже у разбойников и крокодилов они состоят в ангельском чине. 
As crianças são santas e puras. Até os bandoleiros e os crocodilos Ihes dão a patente de anjos. (tradução nossa) ${ }^{83}$

A Kátia-criancinha, apesar do destino trágico e da doença, mencionados mais de uma vez no texto, é confiante, risonha e sábia. A maneira de encarar o mundo, que Nikolai Stepánovitch nota no seu rostinho infantil ("Tudo o que se faz neste mundo é belo e inteligente"....) repetir-se-á, numa forma mais complexa, nos pensamentos de Dmítrii Gúrov, num dos episódios mais pungentes e simbólicos de "A dama do cachorrinho":

Gúrov pensava em como, na realidade, refletindo-se direito sobre isso, tudo é belo neste mundo, tudo, com exceção do que nós mesmos pensamos e fazemos, quando nos esquecemos dos objetivos elevados da existência e de nossa própria dignidade humana. (321)

Cada fragmento das recordações constrói-se segundo o esquema da contraposição ao tempo presente, e o passado, refratado pela consciência da personagem, é sempre desmesuradamente melhor do que aquele. Em Liza e Kátia adultas, não encontramos já os traços tão carinhosamente lembrados pelo narrador; ficaram, no passado distante, a sinceridade, a confiança e a espontaneidade das crianças.

No entanto, nesse período passado de vida (fim dos anos 60 e início dos 70), vemos uma família feliz, uma casa repleta de risos infantis e jogos, em que participam um cão e um gato, uma casa em que à noite pai e mãe banham juntos os filhos. E como símbolo desse lar apresenta-se, qual festa diária, o ruidoso almoço de comida simples mas saborosa, e a sua álacre atmosfera é lembrada pelo professor em contraposição ao ambiente penoso e tedioso das reuniões à mesa de agora:

Antes, eu gostava do jantar ou era indiferentea ele... O posto de general e a fama privaram-me para sempre do schtchi, dos

\footnotetext{
${ }^{83}$ A. TCHÉKHOV, 02.01.1889

Disponivel em: https://royallib.com/read/chehov_anton/tom_21_pisma_1888_1889.html\#389120
} 
saborosos bolos de carne, do ganso com maças e da brema com trigo sarraceno. Eles tiraram-me também a criada Agacha, velhota faladeira e de riso fácil...Não existem a alegria de antes, as conversas desembaraçadas, os gracejos, os risos, não há mais carinhos mútuos nem aquele contentamente que perturbava as crianças, minha mulher e a mim, quando nos reuníamos na sala de jantar; para mim, homem ocupado, o jantar era um tempo de descanso e de encontro, e para a mulher e os filhos, uma festa, breve, é verdade, mas luminosa e alegre, quando sabiam que eu, por meia hora não pertencia à ciência, nem aos estudantes, mas unicamente a eles. Não existe mais a capasidade de se embriagar com um só cálice, não existem Agacha, nem brema com trigo sarraceno, nem aquele barulho com que sempre se acholhiam os pequenos escândalos do jantar, como uma briga do cachorro e do gato debaixo da mesa ou a queda do lenço amarrado na face de Kattia para dentro do prato de sopa. (127)

Precisamente aqui, nesse episódio, a mesa (e a reunião à mesa) aparece no seu significado simbólico direto: personificação da reunião da família, amigos, do lar e do conforto.

Pode considerar-se um importante pormenor desse fragmento a presença de animais vivos reais, como já assinalámos; em todos os demais casos, a eles faz-se referência apenas metafórica ou simbólica.

Para além da família da personagem, há um círculo significativo de amigos. Ele tinha um amigo, oftalmologista, que lhe era tão chegado, que, após a sua morte, Nikolai Stepánovitch adotou a sua filha órfã. O seu talento e glorioso nome, ademais, permite-lhe ter amizade com as pessoas mais interessantes do seu tempo:b

As suas relações são das mais aristocráticas; pelo menos, nos útimos vinte e cinco a trinta anos, não existiu na Rússia sábio famoso com quem não mantivesse trato íntimo. Atualmente, não tem com quem manter amizade, mas falando-se do passado, a longa lista dos seus glorios amigos termina com nomes como Pirogov, Kaviélin e o poeta Niekrrassov, que Ihe concederam a sua mais cálida e sincera amizade. (101)

Todos os três, o cientista famoso, o eminente ativista social e o grande poeta, eram partidários do movimento liberal na Rússia, os chamados "sessentistas" ("шестидесятники"). Essa recordação deu azo a 
que, ainda em vida de Tchékhov, se discutisse se Nikolai Stepánovitch era um "sessentista", de tanto que a sua figura era típica do representante dos anos sessenta, tempo da ascensão do movimento social e ideológico na Rússia. A discussão estendeu-se até à crítica soviética. A nosso ver, para Tchékhov, que examinava "cada caso separado", tal tipização não tinha sentido, e nós não nos deteremos na questão.

Nessa etapa da vida, já se consolidara aquilo que Nikolai Stepánovitch considerava "uma composição feita com talento". Contudo, não sem ajuda do autor, às vezes a personagem deixa escapar algumas coisas. E, no quadro ideal pintado, o leitor nota alguns pormenores que escapam ao idílio. Muitos problemas do presente começam no passado.

Assim, o marido e pai feliz reserva-se meia hora por dia para estar com a família. É possível que tenha sido isso o que ensejou o que, mais tarde, causaria aflição ao velho professor.

Observo-as, e somente agora, durante este jantar, torna-se absolutamente nítido para mim que a vida interior de ambas já escapou há muito da minha observação. Tenho a impressão de que um dia vivi em casa, com a família de verdade, e agora estou jantando como visita, em casa de uma esposa que não é a verdadeira, e vejo uma Lisa também inautêntica. Passou-se em ambas uma mudança brusca, eu não percebi o processo prolongado segundo o qual essa mudança se processou, e não é de se estranhar que não compreenda nada. Por que se deu essa mudança? Não sei. (128)

Também para a menina órfã não é doce a vida na nova família. Ela está constantemente doente e necessita de médicos. É característico que a sua doença seja relacionada com a face (o que se expressa com uma faixa atada), um sintoma que lembra, posteriormente, o tique na face do professor adoecido. Os de casa não the querem, castigam-na sem razão e não respondem às suas perguntas, ela não interessa a ninguém, não faz falta a ninguém, logo a enviam para uma escola e ela aparece somente nas férias. É bem provável que o "pequeno escândalo", a queda da faixa do seu rosto no prato de sopa, tenha suscitado o riso geral precisamente sobre ela, o que não foi entendido por Nikolai Stepánovitch. Pode-se 
compreender por que ela não tende a ficar na companhia de crianças, que poderiam tornar-se suas amigas, da mulher que lhe subsituíra a mãe, mas na da única pessoa que nem intervém por ela à vista das ofensas que the fazem, e sente por ela apenas pena. Já isso Ihe basta para torná-lo seu ídolo.

Não admira que a relação entre as mulheres adultas seja de ódio mútuo.

Tanto Vária como Lisa odeiam Kátia. Esse ódio me é incompreensível...(125)

Kátia depreza minha mulher e minha filha com a mesma intensidade com que elas a odeiam...

-Que nulidades!... Nulidades! (133)

Gradualmente, a vida do professor toma a forma duma composição ideal, com que, na juventude, ele pudera somente sonhar e que "se desfizera em pedaços", como ele observa a Kátia com tristeza, posteriormente. É característico que o episódio que a personifica maximamente, começa como que no presente, e somente no fim o leitor fica a saber que tudo o que está dito, ficara no passado: a Nikolai Stepánovitch dói reconhecer essa principal perda até para si próprio.

Eu sei o que hei de expor, mas não como vou fazê-lo, por onde começarei e como irei terminar. Na cabeça, não há uma frase pronta sequer. Mas basta-me passar os olhos pelo auditório e proferir e estereotipado: "Na aula passada, paramos no...", e as frases voam-me da alma numa longa fieira, e, lá vai matéria! Falo com incoercível rapidez, apaixonado, e, parece, não há força capaz de interromper a torrente do meu discurso. Para discorrer bem, isto é, de maneira não enfadonha, e com proveito para os ouvintes, é preciso ter, além de talento, habilidade e experiência, deve-se possuir a noção mais nítida sobre as próprias forças, sobre aqueles a quem se dá a aula e sobre o objeto do discurso. Ademais, é preciso saber o que se pretende, e vigiar tudo atiladamente, não perdendo por um instante sequer o campo visual.

Um bom regente de orquestra, ao transmitir o pensamento do compositor, executa simultaneamente vinte tarefas: lê a partitura, agita a batuta, observa o cantor, faz um movimento 
ora na direção do bombo, ora do corne-inglês etc. O mesmo faço eu, dando aula. Tenho na frente cento e cinquenta rostos, que não se parecem entre $\mathrm{si}$, e trezentos olhos que me encaram bem na frente. $O$ meu objetivo é vencer essa hidra de muitas cabeças. Se em cada momento da minha aula tenho uma noção nítida do grau da sua atenção e da intensidade da sua aprendizagem, ela está em meu poder. O meu outro inimigo aloja-se em mim mesmo. É a variedade infindável de formas, fenômenos e leis, eu grande número de pensamentos meus e alheios por eles condicionados. A cada momento, devo ter a agilidade de arrancar desse material imenso o que é mais importante e necessário e, com a mesma velocidade com que ocorre o meu discurso, revestir o meu pensamento de uma forma que seja acessível à compreensão da hidra e que desperte a sua atenção, sendo então necessário vigiar com muita perspicácia para que os pensamentos se transmitam não na medida do seu acúmulo, mas numa ordem determinada, indispensável à correta composição do quadro que eu quero pintar. Em seguida, procuro fazer com que o meu discurso tenha estilo literário, as definições sejam breves e exatas, a frase, se possível, singela e bonita. A cada momento, devo frear-me e lembrar que tenho à disposição apenas uma hora $\mathrm{e}$ quarenta minutos. Numa palavra, não falta trabalho. Ao mesmo tempo, é preciso fazer de si um cientista, um pedagogo, um orador, e as coisas vão mal se o orador vence o pedagogo e o cientista, ou vice-versa.

Discorre-se um quarto de hora, meio hora, e eis que, observa-se, os estudantes começam a olhar para o teto, para Piotr Ignátievitch, um apanha o lenço, outro procura sentar-se mais comodamente, um terceiro sorri aos próprios pensamentos... Isso significa que a atenção está cansada. É preciso tomar medidas. Aproveitando a primeira oportunidade, digo algum trocadilho. Todos os cento e cinquenta rostos sorriam largamente, os olhas brilham alegres, ouve-se por um curto tempo o rugir do mar...Rio também. A atenção se refrescou, e eu posso continuar.

Nenhuma discussão, nenhum jogo ou divertimento me proporcionaram jamais o prazer que me dão as minhas aulas. Somente na aula eu podia entregar-me plenamente à paixão e compreendia que a inspiração não é uma invenção de poetas, mas que existe de fato. E eu penso que Hércules, após a mais picante das suas proezas, não sentia tão doce langor como o que eu experimentava depois de cada aula (112).

O ritmo dessa recordação é veloz e impetuoso, e o léxico, veemente e vivo: apaixonado, alma, incoercível, não enfadonha, talento, jogo ou divertimento, bonita, trocadilho, sorriam, os olhos brilham, rio, refrescou, a inspiração, doce langor, das suas proezas.

E a pessoa que se ergue diante do leitor, não é apenas um cientista 
genial, como também uma personalidade multifacetada e de vastos conhecimentos. No seu monólogo, junto com o tema duma conferência, há referências à História Antiga e a vários tipos de arte (maestro, pintor, literato, orador, poeta, cantor, quadro, anfiteatro), à música, ao desporto (na tradução brasileira, em lugar de "спорт", traduziu-se "спор" "discussão"). Trata-se duma pessoa que se encontra no auge dos seus sentimentos e do seu intelecto e calcula as suas forças, uma pessoa caracterizada pela perseguição dum objetivo, desejo de vitória, despotismo, flexibilidade, autoconfiança, uso da experiência própria e da alheia, atenção concentrada na tarefa por realizar e espirituosidade. Para além de tudo isso, ela é um pedagogo e psicólogo magnífico, extremamente atento aos seus ouvintes e consciente da menor reação deles.

Todo o episódio está impregnado do espírito da Antigüidade, a que se alude já no relato acerca do porteiro Nikolai e a sua consciência mitológica. Testemunham-no o auditório, construído em forma de "anfiteatro", e a menção a um orador e à hidra, objeto de um dos doze trabalhos de Hércules. O próprio professor apresenta-se precisamente qual poderoso herói da Antigüidade.

No léxico, há notas indicadoras dum fundo belicoso:

Não há força capaz de interromper

O meu objetivo é vencer...

em meu poder

inimigo

A personagem luta e vence.

Nessa recordação, aparece também o elemento erótico, no qual, para além do léxico (o prazer de entregar-me plenamente à paixão, doce langor), se faz referência à picante façanha erótica de Hércules e ao mito da sua potência sexual: numa única noite, deitou-se com as cinquenta filhas virgens do rei, que visitaram o seu leito uma a uma e depois tiveram cada qual um filho dele.

Assim como em outras recordações, alguns elementos da 
composição, temas e símbolos apresentam-se, nesse trecho, sob outra luz, e estabelece-se especialmente um paralelo com o sexto e último capítulo. Nele, por meio do ambiente limitado e estranho do quarto de hotel e as batidas do relógio, que marcam impiedosamente a passagem dos preciosos minutos, transmite-se como o tempo e o espaço literalmente engolem e dissolvem um homem desamparado diante deles. No fim das suas notas, Nikolai Stepánovitch, novamente chamando-se "herói" (sou um herói de quem a minha pátria se orgulha (157), reconhe com amargura: Estou vencido. (159)

Já na citada recordação, têm-se o mar simbólico simplificado, o elemento natural, o espaço inabarcável pelo olho e o cálculo exato e bem sucedido do tempo até ao último minuto, isto é, a completa vitória do homem sobre o espaço e o tempo.

Em lugar de raciocínios monótonos e tediosos e verdades batidas, não se têm, agora, frases feitas, mas um discurso baseado na inspiração; uma alma livre (as frases voam-me da alma numa longa fieira), não o entorpecimento da alma (paralisia da alma), como no último capítulo. Encontramos, também, outros símbolos, já citados por nós antes: frescor em contraposição a secura (a qual se manifesta no parágrafo seguinte à recordação, assim que Nikolai Stepánovitch passa à descrição do seu estado e a qual ele tenta superar com ajuda de água) e a imagem de aves no seu livre vôo, cifrada na palavra "fieira", à diferença da coruja com o seu pio sinistro, sobre o fundo do "tédio", que se repete várias vezes e "não tediosamente".

Temos, diante nós, um quadro figurado duma vida consciente feliz e genuína, que abarca todas as esferas principais. Tal vida começa inspirada e finda feliz, na nota mais alta.

O único porém que ensombrece o quadro (o que o professor descreveu) é apenas a magnífica conferência dum estudioso genial. O que existe além do âmbito do seu trabalho, ou seja, a sua casa, a família e pessoas próximas, não participam em "tal" vida, e até os estudantes, pelos quais tudo isso acontece, constituem, para ele, tão-somente uma 
hidra multicéfala, multiocular e informe, com que ele se bate e que precisa vencer.

E, finalmente, as recordações mais longas, cronologicamente as últimas - o relato da vida de Kátia.

Ela tem vinte e cinco anos, e a evolução da sua paixão pelo teatro começara dez anos antes (Nikolai Stepánovitch tem já cinquenta e dois.). O tempo desse período, assim, é convencional, do início dos anos setenta ao início do decênio seguinte.

A recordação está construída dum jeito, que o leitor recebe a informação logo de duas vozes - o relato de Nikolai Stepánovitch e a carta de Kátia - uma parte dos quais existe na exposição do professor, e parte é citada por ele.

$\mathrm{Na}$ trajetória de vida dele insere-se a trajetória de vida de Kátia, como se em ritmo rápido repetindo etapas e estados psicológicos percorridos por ele: paixão, entusiasmo, esperanças, sonho realizado, profissão prazerosa, felicidade, amor, planos para o futuro, decepção, naufrágio das esperanças e a tentativa de suicídio (morte simbólica).

Em conformidade com isso, muda a estilística. Todo o espisódio está impregnado de teatralidade e do léxico cênico (peça, desempenho, saguão, camarote, monólogo, receitas, ensaios, papéis, palco, público) e, no todo, lembra uma peça curta - perpassa a vida duma jovem mulher, esvaziando-a e esmagando-a, tornando decepcionada e cínica uma alma jovem, ardente e crédula. Com meios mínimos (a personagem conta com indiferença o que ocorre, e a própria ação passa-se algures, longe), o autor mostra o processo dessa mudança. Alguns fragmentos da biografia de Kátia repetir-se-ão na vida de Nina Zariétchina da futura "A gaivota".

O teatro está presente, aqui, em várias hipóstases, como sonho, como profissão e como empreendimento comercial:

Kátia passou a escrever-me que seria bom construir em alguma cidade do Volga um grande teatro, em base de sociedade anónima, e atrair para a empresa comerciantes ricos e armadores; as receitas seriam enormes, e os atores teriam 
participação nos lucros (121)

E como recinto:

Como outrora, nem nos corredores nem no foyer eu consigo encontrar um copo de água limpa. Como outrora, os criados me impõem uma multa de vinte copeques pela minha peliça (119)

O caráter ilusório e enganoso da vida teatral e o cruzamento de paixões falsas com o verdadeiro sofrimento aproximam esse episódio do estado de espírito reinante no segundo capítulo. E Nikolai Stepánovitch, conscientizando-se da sua hipocrisia, extrai palavras precisamente do léxico teatral:

Viajara quase quatro anos, e, todo esse tempo, devo confessar, desempenhei em relação a ela um papel bastante estranho e pouco invejável.(123)

Mas Kátia, no início do seu caminho, não nota essa dualidade; para ela, o teatro é a vida. O seu maravilhado monólogo repete quase textualmente as apaixonadas palavras do professor acerca da Ciência:

Ela me assegurava que o teatro, mesmo na sua forma atual, estava acima da sala de aulas e dos livros, acima de tudo no mundo. O teatro era a força que reunia em si todas as artes, e os atores, uns missionários. Nenhuma arte e nenhuma ciência, isoladamente, era capaz de atuar tão forte e radicalmente sobre a alma humana como o teatro, e não era, portanto, em vão que um ator de importância média desfrutava no país uma popularidade muito superior à do melhor cientista ou pintor. $\mathrm{E}$ nenhuma atividade pública podia trazer tão grande prazer $e$ satisfação como a teatral. (120)

Nenhuma discussão, nenhum jogo ou divertimento me proporcionaram jamais o prazer que me dão as minhas aulas. Somente na aula eu podia entregar-me plenamente à paixão e compreendia que a inspiração não é uma invenção de poetas, mas que existe de fato. E eu penso que Hércules, após a mais picante das suas proezas, não sentia tão doce langor como o que eu experimentava depois de cada aula. (112)

Emitindo o suspiro derradeiro, ainda hei de crer que a ciência constitui o mais importante, o mais belo, o mais necessário na 
vida do homem, que ela sempre foi e será a manifestação mais elevada do amor, e que somente por meio dela o homem vencerá a natureza e a si mesmo. Essa fé talvez seja ingênua e injusta em seu fundamento, mas eu não tenho culpa se creio assim e não de outra maneira; sou incapaz de vencer em mim essa fé. (113)

Para além duma quantidade de intersecções, chama a atenção a mesma adoração da profissão escolhida, que une as personagens; em ambos os casos, ela torna-se quase um culto religioso. Nikolai Stepánovitch até fala em crença, e, no caso de Kátia, o autor escolhe palavras reforçadoras dessa característica: súplice, rezava, missionários, santa ingenuidade, cantava.

Para Kátia, o teatro é a encarnação da harmonia da vida, e, quando a realidade cessa de corresponder às suas expectativas, como no caso de Nikolai Stepánovitch, os culpados são os seus colegas e o ambiente. E também, como ele, no fim de contas, ela reconhece a sua própria incapacidade.

Somente as descrições do período, em que Kátia estava enlevada e feliz, lembram estilisticamente as recordações anteriores. No todo, porém, nessa descrição dum lapso de tempo, não há já mudança do signo semântico nos motivos, nem nos símbolos; ao contrário, estabelecem-se paralelos com o tempo corrente real das notas. Sobretudo, é já conhecido o ritmo monótono. Assim como nos primeiros capítulos, nós vemos uma contagem exata do tempo:

Antes de passar meio ano, recebi uma carta altamente eufórica e poética ...(121)

Em todo caso, tudo pereceu correr bem um ano e meio ou dois: Kátia estava amando, acreditava em seu trabalho e era feliz...(121)

Viajara quase quatro anos, (123)

e as reflexões pesadas e didáticas dum velho ranzinza.

Aparece várias vezes a palavra "скучный" (tedioso): 
...A desgraça de ter espírito não é uma peça cacete, sopra sobre mim do palco aquela mesma rotina, que me enfadava quarenta anos atrás... (120)

... «Горе от ума» не скучная пьеса, то на меня от сцены веет тою же самой рутиной, которая скучна мне была еще 40 лет назад ${ }^{84}$

Em resposta, enviei a Kátia uma carta comprida e, devo confessar, muito enfadonha. (122)

В ответ я послал Кате длинное и, признаться, очень скучное письмо. ${ }^{85}$

...cartas compridas, maçantes, que popodia muito bem ter deixado de escrever. (123)

...длинные, скучные письма, которых я мог бы совсем не писать. ${ }^{86}$

Pode notar-se que, nos exemplos supracitados, no texto tchekhoviano repetem-se скучно е скучный, ao passo que, na tradução brasileira, empregam-se os sinónimos cacete, enfadonha, maçantes.

O meio de Kátia cometer suicídio - envenenamento - faz eco ao ar "enve-nenado" (Na tradução brasileira, omitiu-se a frase "Кажется, Катя пробовала отравиться" - Parece que Kátia tentara envenenar-se.). "Табун диких лошадей" (Manada de cavalos selvagens) tem o mesmo matiz negativo que o pio de coruja e o uivo de cão; "зловещий симптом" (sinistro sintoma) e traz à lembrança "зловещее зарево" (o reflexo sinistro e enorme dum incêndio) da tempestuosa noite dos pardais, e a personagem procura "стакан чистой воды", "um соро de água pura" (salvação simbólica da secura-tédio), como no primeiro capítulo e no quarto.

É também sintomática a mudança de motivo musical: se o início da paixão de Kátia se transmite pelo verbo cantava, então, em seguida, surge um amargo e fantástico "Estamos cantando óperas diferentes" (122). Para além disso, para Nikolai Stepánovitch, " ...há musica sem

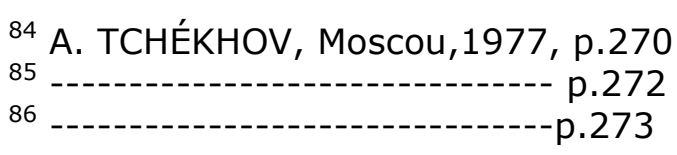


qualquer necessidade" (119).

E, pela primeira vez nas recordações, surge o tema principal das notas, o tema da morte: "Enterrei ontem o meu filho" (123).

Para além das provações de Kátia, como antes, no nosso campo de visão, está a própria personagem-narrador. De sob o véu do dever e dos cuidados de tutor, o professor deixa transparecer uma clara indiferença pelos sofrimentos de alguém do seu círculo mais próximo. Até nos momentos mais trágicos da vida de Kátia, ele experimenta apenas confusão, embaraço e estranhamento. As frases incisas "кажется" (parece), "мог догадаться" (pude perceber) е "надо думать" (é preciso pensar) expressam inexatidão e indecisão e, no todo, falta de interesse:

...não ter tido tempo e vontade de observar o início e desenvolvimento da paixão...(118)

Ela cansava-nos com as suas conversas contínuas sobre teatro. Minha mulher e meus fillhos não a ouviam. Somente eu não tinha coragem de recusar-lhe atenção. (119)

Nunca partilhei os arrebatamentos teatrais de Kátia. (119)

E um belo dia, Kátia ingressou numa companhia e partiu se não me engano para Ufá (120)

Mais tarde, por algumas alusões, pude perceber que ocorrera uma tentativa de suicídio. Parece que estivera depois gravemente doente.(123)

É preciso assinalar que, no presente caso, os próprios pensamentos acerca do teatro ocupam a personagem-narrador muito mais do que a doença de Kátia e a morte do filho dela. Temos aqui, diante de nós, o mesmo caráter formado, o mesmo autor do diário, apenas ainda não adoecido, não torturado pela insónia e por "pensamentos envenenados".

O fragmento, tanto pelo tempo quanto pelos caracteres formados, está maximamente aproximado do tempo corrente das notas. Testemunha-o a última frase dessa recordação, frase que é uma ponte entre o passado e o presente: 
Atualmente, Katia vive a meia versta de minha casa. (123)

Havendo distribuído cronologicamente as recordações da personagem na linha composicional da novela, acompanhadas cada qual duma análise, nós vimos o professor no transcurso de todas as etapas e em cada decénio da sua vida; mais do que isso, nós assinalámos como se processaram nele algumas mudanças graduais: afastamento dos parentes próximos, substituição de sentimentos e emoções por reflexões, tudo o que o levou à sensação da perda de "algo importante" na vida, o que ele próprio, na sua forma habitual, chamou de "idéia geral". E, se parafrasearmos a observação perspicaz de Kátia,

Não tem sensibilidade, não tem ouvido para a arte. Esteve ocupado a vida inteira e não teve tempo de adquirir essa sensibilidade.(150)

poderemos dizer que ele não teve tempo, nem vontade, de adquirir a capacidade de compreender a vida e apreciá-la.

\subsection{Pormenor}

É impossível estudar a obra de Tchékhov, sem tratar da especificidade dos pormenores usados por ele. Precisamente a concisão, o impressionismo, o simbolismo, a sutilíssima pincelada, capaz de transmitir tanto uma imagem quanto uma sensação e um estado de espírito e caracterizar o mundo interior das personagens, especialmente quando tal contradiz as suas próprias palavras e ideias, tudo isso é uma das principais características do estilo do escritor. O pormenor usado por Tchékhov pode ser, ao mesmo tempo, material, trivial e simbólico, isto é, dotado de significado tanto direto quanto figurado, e constituir simplesmente uma minudência lírica e um meio do subtexto.

Z. Khainadi, ao analisar a diferença entre o pormenor em Tolstói e em Dostoiévski, chama a atenção para o facto de que, dada a pouca extensão das obras de Tchékhov, o pormenor insignificante está 
maximamente concentrado e tem uma carga ideológica significativa, tornando-se um importante componente da integridade e unidade da composição ${ }^{87}$. Nisso reside a dificuldade e variedade da sua interpretação.

Encontram-se também pormenores caracterizadores, simbólicos ou fortuitos, que migram de texto em texto. Para as obras escritas em primeira pessoa isso tem um significado especial, porquanto é simultaneamente opinião tanto da personagem-narrador quanto do autor. Assim, por exemplo, em "Uma história enfadonha", Nikolai Stepánovitch caracteriza os olhos de Hnekker como "de caranguejo", expressando, com isso, a sua grande antipatia a ele. Mas "olhos de caranguejo" já apareceram em textos de Tchékhov, e o que é especialmente importante, em contos da fase inicial, na qual ainda não surgira um dos princípios básicos do escritor, a objetividade, e isso significa a atitude do próprio autor está expressa muito claramente:

Kaléria Ivánovna, comprida e magra morena, de sobrancelhas pretíssimas e olhos de caranguejo saltados, ia ver Egóruchka todos os dias. (tradução nossa) $)^{88}$

Lá pandegavam... Sobre a mesa havia garrafas. À mesa estavam sentados algumas figuras com olhos de caranguejo saltados (tradução nossa)

Assim, graças a um pormenor-metáfora, que migra dum texto a outro, pode concluir-se que à opinião do professor se une a do autor, agindo sobre o leitor e reforçando a impressão negativa geral, causada por Hnekker. É particularmente polémico o pormenor casual, "fortuito", que, à primeira vista, parece não ser meio de expressão dalguma característica e, pelas leis da literatura "pré-tchekhoviana", não seria necessário ao texto ou, pelo menos, não obrigatório. Como já

\footnotetext{
87 Disponivel em: http://lit.1september.ru/article.php?ID=200203005

${ }^{88}$ A.TCHÉKHOV, Moscou,1974, p.418.
} 
mencionámos no nosso trabalho, tal particularidade do estilo tchekhoviano foi notada pelos críticos mais talentosos ainda durante a vida do escritor, porém, não havendo sido compreendida, foi percebida como defeito, incapacidade ou falta de vontade de selecionar o material e subordiná-lo a uma ideia (Mikhailóvski). Permanece aberta até hoje e é polémica a questão de por que Tchékhov, para quem, pelo seu próprio aforismo, "a concisão é irmã do talento" , introduz minudências aparentemente desnecessárias em textos harmonicamente construídos, em que cada elemento se enquadra num sistema determinado. A. P. Tchudakov, em estudo do mundo dos temas e acontecimentos de Tchékhov, julga que os pormenores materiais são escolhidos não para ilustração dalguma ideia, mas para a criação duma ilusão de naturalidade, e precisamente a "fortuidade" é o princípio organizador do sistema literário tchekhoviano em todos os níveis; o objeto "insignificante", desse modo, adquire os mesmos direitos do caracterizador. E. S. Dóbin, por sua vez, afirma que o pormenor, em Tchékhov, torna-se um foco semântico, um condensador da ideia do autor, um meio de compensação do enredo frou $\times 0^{89}$. Com a simplicidade e o ordinário, corriqueiro, a narrativa de Tchékhov enche-se e alastra-se às custas do papel especial que o pormenor desempenha no texto.

A. Stepánov ${ }^{90}$ assinala dois níveis de "fortuito" no mundo artístico de Tchékhov: o "fortuito" para o leitor, que é incapaz de ligar o fragmento, o pormenor, com a integralidade do texto, e o "fortuito" para a personagem. No primeiro caso, o fortuito apresenta-se, vale dizer, é percebido pelo leitor ou como sinal de imperfeição da forma ou como presença duma integridade do mundo não selecionada, e a solução da questão acerca da sua função, no tempo presente, é impossível. Para o estudioso, o tratamento textual vem a ser importante apenas no caso de exame do "fortuito" para a personagem, quando desponta o embaraço das

\footnotetext{
${ }^{89}$ E.DÓBIN, Leningrado, 1981.

${ }^{90}$ Iz veka XX v vek XXI, Moscou, 2007, p.270.
} 
personagens ante a inexplicabilidade ou fragmentaridade do mundo, o que é característico do texto tchekhoviano, uma vez que, no seu sistema literário, existe um paradoxo: qualquer processo que tenha um objetivo ou função, não atinge o objetivo e não desempenha nenhuma função.

Nós concordamos com os estudiosos que afirmam que nenhum elemento do texto tchekhoviano, - pormenor, frase, personagem ou situação, - é alheio a ele; ao contrário, cada qual deles está ligado com os outros que formam a composição da obra, e, em conformidade com isso, pode encontrar-se uma certa lógica, uma explicação ao que, à primeira vista, é percebido como "fortuito".

A nossa hipótese é que o pormenor "fortuito" constitui um importantíssimo meio do subtexto autoral e como tal desempenha duas funções principais na novela estudada. Ao focalizar em si a atenção do leitor, ele funciona no nível do subconsciente e da intuição quase imperceptivelmente, em primeiro lugar, ao traçar paralelos associatórios entre as situações e as personagens e, com isso, manifestar, por trás da opinião do professor, a visão do autor acerca delas, e, em segundo, ao trabalhar para a ampliação do tempo e do espaço literário, isto é, para a criação do cronótopo da novela.

\section{8 personagens}

Em "Uma história enfadonha", à diferença de muitos outras obras de Tchékhov, não há descrições da natureza, nem, em geral, nenhumas descrições (à exceção do interior do apartamento de Kátia); nelas, os pormenores, a par da estrutura rítmica, costumam pôr a descoberto a atitude do autor em relação ao que se passa. Nikolai Stepánovitch, ocupado em escrever apontamentos, está concentrado no seu mundo interior e nas pessoas do seu convívio, o que leva a que o pormenor desempenhe o principal papel na revelação das figuras das personagens, tanto das centrais quanto 
das aparecidas uma única vez mas, apesar disso, merecedoras de descrição, bem como das episódicas, citadas de passagem nas recordações. Todas elas, inclusivamente as últimas, estão de certa maneira incluídas na composição; entre elas, há laços, estendem-se fios e sublinham-se paralelos, aguçando a atenção não apenas para a semelhança dos traços dominantes da personalidade, mas, às vezes, também para a completa disparidade entre eles. É especialmente importante atentar para pormenores e personagens casuais, porquanto eles, que não têm importância para o narrador, é que constituem o meio de expressão do subtexto do autor.

No estudo da novela, em relação às personagens, devemos começar pelas pessoas mais próximas de Nikolai Stepánovitch, ou seja, os membros da sua família, representada por três mulheres: a esposa Vária, a filha Liza e a enteada Kátia (há um filho, citado de passagem); para tal, é preciso recordar algumas particularidades do período histórico em que se escreveu a obra.

No final do século 19, novas idéias acerca da questão feminina (o papel da mulher na família e na sociedade, a possibilidade de divórcio, educação e trabalho, emancipação etc.) desencadearam acesas discussões, subentende-se, inclusivamente em páginais de jornais e revistas e na literatura ${ }^{91}$. O tema era tão importante e interessante para Tchékhov, que ele, sendo ainda estudante do quarto ano de Medicina, se põe a escrever um trabalho científico, "História da autoridade sexual", no qual, sob influência de Darwin, pretendia estudar as relações entre os sexos no processo histórico; o tratado não foi concluído, mas podem encontrar-se ecos

\footnotetext{
91 No livro Чехов и проблема идеала (Tchékhov e o problema do ideal), M. Odiésskaia analisa em minúcia o desenvolvimento desse processo na literatura russa.
} 
seus em muitas obras do escritor.

A esse candente tema dedicou-se a novela "Sonata a Kreutzer" (1891), de Tolstói. Obra sintonizada com a época, ela, embora discutível, causou forte impressão aos leitores, arregimentando uma enorme quantidade tanto de partidários quando de adversários das ideias de Tolstói, e ensejou uma nova vaga de discussões. Iniciada em 1887, concluiu-se em Agosto de 1891. Isto é, a última etapa da sua escrita coincide com o período de escrita de "Uma história enfadonha". Crê-se que Tchékhov a haja lido somente após a sua publicação. No entanto, ainda antes da conclusão, o manuscrito de Tolstói, por obra da sua esposa, Sófia Andréevna, e dos seus amigos e à revelia do escritor, foi várias vezes copiado a mão e chegou até a ser publicado em litografias já na metade de 1889 e, assim, era já conhecido do público muito antes de ser levado ao prelo. No mesmo ano de 1889, Tchékhov, simultaneamente com "Uma história enfadonha", continuou a escrever um romance, mas, já pelo beirar do fim do ano, pô-lo de parte e não o retomou. Muito desse romance, depois, foi para obras suas, mas algo foi parar às Obras reunidas como inconcluso, como o conto "Письмо" ("Carta") 92 , em que se fala, muito provavelmente, de não outra coisa que não de "Sonata a Kreuzer". A data exata do conto, mais exatamente, desse fragmento de romance não concluído, é desconhecida, mas, em todo o caso, ele não foi escrito depois do fim de 1889 , isto é, antes da publicação da referida obra de Tolstói.

Tal facto, a par de outros ${ }^{93}$, permite-nos supor que também

\footnotetext{
${ }^{92}$ Há três contos com tal título; referimo-nos ao datado de 1889.

93 É difícil imaginar que Tchékhov, que estava sempre a par das novidades literárias e para quem Tolstói constituía o maior vulto da literatura, pudesse ter deixado passar o manuscrito tolstoiano
} 
Tchékhov se incluía no número de leitores conhecedores da novela tolstoiana ainda em manuscrito e precisamente no período em que estava a escrever "Uma história enfadonha". A partir dessa suposição, alguns paralelos entre as duas novelas, em relação ao tema da mulher e ao do matrimónio, podem ver-se não somente como tendências do tempo, senão também como referência direta de Tchékhov à rumorosa obra do seu confrade mais velho. E, apesar de toda a diferença de tratamento da questão feminina, a semelhança entre "Sonata a Kreuzer" e "Uma história enfadonha" manifesta-se não apenas no nível do tema, mas também no da composição (a forma de confissão, a importância do subtexto musical) e até em alguns aspectos concretos, relacionados, sobretudo, com um determinado tipo feminino e convenções sociais referentes ao casamento e às relações sociais.

Assim, das três mulheres de "Uma história enfadonha", duas, a esposa e Liza, apesar da "individualização de cada caso em particular", mostram-se como que ilustração do relato de Pósdnychev, personagem de "Sonata a Kreuzer". De acordo com as suas ideias, o objetivo vital das mulheres é estender a rede e atrair homens para a armadilha, o casamento. Para a consecução disso, empre-ga-se todo um arsenal de meios, que vai duma roupa e dum comportamento tentadores à pretensão a interesses comuns com os homens e a um alto nível espiritual e intelectual.

Experimente dizer a verdade a alguma das mães ou à própria moça, isto é, que elas estão ocupadas unicamente com a caça a algum noivo.Que ofensa, meu Deus! Mas todas elas só fazem isso, e não têm nada mais por fazer. $\mathrm{E}$ o que é terrível, é ver, às vezes, ocupadas com isso moças bem novas e inocentes. E mais uma vez, se isso ao menos se fizesse abertamente... Mas é tudo um embuste. "Ah, a origem das espécies, como é interessante! Ah, Lisa interessa-se muito pela pintura! O senhor irá à exposição? Como é instrutivo? E o passeio de troica, e o espetáculo teatral, e a sinfonia? Ah, como é admirável! A minha Lisa é louca por música. Mas por que o senhor não tem essas mesmas convicções? E andar de barco! ..." E o pensamento é sempre o mesmo: "Toma, toma-me, toma a minha Lisa! Não, a mim! Ora experimenta ao 
menos!...*

Cego, enganado e incapaz de resistir, o homem cai nas bem armadas "ciladas sexuais".

Desse modo, realiza-se um casamento por amor, precedido por uma alegre animação bem torpe.

Durou pouco, o meu noivado. Não posso lembrar agora esse tempo sem um sentimento de vergonha! Que ignomínia! ${ }^{94}$

Após algum tempo, cai a venda dos olhos do homem, e ele vê o que the parece que a mulher na realidade representa - a sua infâmia, estreiteza de horizontes e dependência em relação ao homem. Por mais feliz que um matrimónio tenha começado, com o tempo torna-se insuportável, os cônjuges começam a sofrer. E sobretudo a mulher, absorvida pela procriação, pelo dia-a-dia, pelos inúmeros temores e tribulações inevitáveis, se a família tem filhos:

A maior parte das mães sente justamente isso e, às vezes,
dizem-no, sem querer, assim mesmo. Pergunte à maioria das
mães do nosso círculo de gente abastada, e elas Ihe dirão que,
devido ao medo de que as crianças adoeçam e morram, não
querem ter filhos e que não querem amamentar, se já deram à
luz (...). O prazer que Ihes dá uma criança com o seu encanto, o
encanto dessas mãozinhas, perninhas, de todo o corpinho, o
prazer proporcionado por uma criança é menor que o sofrimento
experimentado por elas, já não digo em caso de doença ou perda
da criança, mas pelo simples medo dessa possibilidade. ${ }^{95}$

As analogias com "Uma história enfadonha" são claras. Nikolai Stepánovitch, outrora ardentemente apaixonado pela bonita, doce de alma, inteligente e esbelta Vária, "que se comiserava" da ciência dele, agora fica perplexo, ao olhar para a velha, gorda e desajeitada mulher de expressão facial embotada. Parece que Vária está a

\footnotetext{
94 Idem, p. 188.

${ }^{95}$ Idem, p. 204.
} 
repetir-se na bonitinha e jovem Liza; a semelhança das duas é citada pelo narrador:

Tem vinte e dois anos. Parece mais jovem, é bonita e lembra um pouco a minha mulher quando moça. (105)

E o caminho de Liza na vida desenvolve-se pelas mesmas regras com as mesmas convenções adotadas pelo círculo deles, tal como o da sua mãe e das mulheres referidas pela personagem de Tolstói:

Você pode ser cem vezes cavalheiro e conselheiro privado, mas, se tem uma filha, nada o garantirá contra o que há de pequenoburguês naquilo, que $\mathrm{o}$ ato de cortejar, de pedir a mão e o casamento introduzem em sua casa e na sua disposição. Eu, por exemplo, não posso de maneira alguma conformar-me com a expressão triunfal que aparece em minha mulher sempre que Hnekker está em nossa casa, não posso também conformar-me com as garrafas de Lafitte, vinho do Porto e xerez, postas na mesa unicamente em sua intenção, para que se convença com seus próprios olhos como vivemos farta e luxuosamente. Não suporto também o riso sacudido de Lisa, que ela aprendeu no conservatório, e o seu jeito de entrecerrar os olhos, quando há homens em nossa casa... Minha mulher e os criados murmuram misteriosamente que "é o noivo"... (126)

E, admitida a hipótese de Tchékhov haver lido o manuscrito de Tolstói no período de escrita de "Uma história enfadonha", tornar-seá óbvia a escolha não por acaso do nome "Liza", se considerarmos o supracitado trecho de "Sonata a Kreuzer" ("A minha Liza é louca por música"...) e, principalmente, o facto de a filha adorada por Pósdnychev também chamar-se Liza.

Segundo a lógica da personagem de Tolstói e deste próprio, por mais que o casamento se tenha realizado por um amor feliz e mútuo, a mulher, especialmente sobrecarregada pela criação dos filhos, que Ihe trazem incontáveis sofrimentos, será sempre infeliz. É infeliz a Vária de Tchékhov, apesar da dignidade, fama e o status de 
general do marido. Toda a sua vida concentra-se na família e somente nesta, daí o "seu jeito de chamar o meu ordenado de nosso ordenado, o meu chapéu de nosso chapéu." É permanente a sua preocupação com os filhos já crescidos, com o facto de que a sociedade notará que Liza está pobremente vestida, com a situação do noivo dela, com o filho, com o oficial militar: "O menino está em país estranho, o soldo é pequeno..." Esses incessantes pensamentos e cuidados preenchem-Ihe toda a existência, e a sua característica permanente tornam-se as lágrimas:

\footnotetext{
Minha mulher se assusta, uma expressão de dor torturante aparece-lhe no rosto.

-Pelo amor de Deus, Nicolai Stiepanovitch! - implora-me soluçando. -Pelo amor de deus, tire de mim este peso! Eu estou sofrendo! ...Ela aperta um lenço contra os olhos e vai chorar no seu quarto(130)

...minha mulher de súbito empalidece e solta um grito alto, com uma voz desesperada, que igualmente não é a sua...ouço por pouco tempo um choro...148)

Abro a porta, descerro valentemente os olhos e vejo minha mulher. Tem o rosto pálido, os olhos de choro (153)
}

Dois traços principais caracterizam a sua personalidade; o primeiro, como já foi dito, é a limitação do seu mundo interior aos filhos; o segundo, a parcimónia e até avareza. Ambos intensificamse por possuírem determinados paralelos no texto. Assim, o primeiro liga-a com uma personagem, que passa quase despercebida nas recordações do professor:

Uma mulher gorda, que gostava dos estudantes porque "cada um deles tem mãe". (107)

O segundo manifesta-se, se notarmos um pormenor fortuito no seu vulto. Ao passar brevemente pelo gabinete do professor, banhada e recendente a água-de-colónia, ela, contudo, está 
"despenteada". Tal pormenor não acrescenta nada à sua caracterização, mas obriga-nos a recordar outra personagem, de penteado negligente, melenas desprendidas dele e ganchos [grampos] de cabelo que caíam constante-mente: Kátia. Para que chama o autor a nossa atenção e que é que pode unir mulheres tão diferentes, tão opostas entre si em todas as suas manifestações? Tal traço é sua atitude absolutamente anormal de ambas em relação ao dinheiro, embora também levada a dois polos: a mesquinha avareza da esposa e a perdularidade de Kátia.

...todas as manhãs, fala meticulosamente...de que o pão, graças a Deus, ficou mais barato, enquanto aaçucar encareceu de dois copeques...104)

..serqá possível que esta mulher velha, muito corpulenta, desejaitada, com uma expressão embotada de preocupação mesquinha e de temor pelo pedaço de pão, de olhar embaçado pelos pensamentos constantes sobre dívidas e pobreza, que sabe falar apenas de despesas e sorrir unicamente aos preços baixos...(104)

E agora, a respeito de Kátia. Ela vem ver-me todos oa dias à tardinha, e naturalmente tanto os vizinhos como os conhecidos não podem deixar de notá-lo. Vem por um instante e leva-me consigo para passear. Tem cavalo próprio e uma carruagem novinha, comprada este verão. Em geral, ela vive à larga: alugou um palacete com um grande jardim, e transportou para lá toda a sua mobília da cidade, tem duas criadas, um cocheiro...PerguntoIhe com frequência:

-Kátia, com o que você vai viver quando esbanjar o dinheiro da herança de seu pai?

- $\quad$ Então vamos ver.

- Esse dinheiro, minha amiga, merece ser encarado com mais seriedade. Foi ganho por um homem de bem, por meio de trabalho honesto.

- $\quad$ O senhor já me disse isso. Eu sei. (149)

É preciso, também, assinalar que, não obstante a clara semelhança entre as posições de vida de mãe e filha, Liza, apesar de tudo, pertence já a outra geração, e esta absorve novas ideias e é um tanto mais livre das convenções. Testemunha-o o facto de, sendo carne da carne da sua mãe, ela, porém, decide-se a um casamento secreto e escandaloso aos 
olhos da sociedade.

No todo, Tchékhov não compartilhava as ideias de Tolstói acerca questão feminina e não considerava a concupiscência masculina como causa da ausência de direitos e humilhação da mulher. ${ }^{96}$

No concernente a Kátia, a figura feminina típica, pintada por Tolstói, não corresponde a ela.

À diferença das outras personagens, com a exceção, é claro, de Nikolai Petróvitch, Kátia foi notada pela crítica ainda em vida de Tchékhov.

A sua figura foi tratada de maneira unânime: ela repete a tragédia do professor, tal como ele, não consegue encontrar uma "ideia geral" na vida, recorre a ele, à única pessoa próxima, por conselho, e ele não sabe quê responder-lhe, com o que sublinha a sua incapacidade. Ambos os dois, apesar do mútuo apego, não escutam nem compreendem um ao outro, como o provam a última cena da "noite dos pardais" e o final. Kátia suscita aos críticos ora irritação, ora pena, no entanto, é preciso assinalar que eles sempre a examinam apenas sobre o fundo do vulto de Nikolai Stepá-novitch, como o reflexo deste ao espelho, como a última, a mais convincente, prova da vida arruinada do professor. Liátski vê-a como uma mandriã estouvada e nervosa, não especialmente inteligente, que diz o que Ihe vem à cabeça, pensamentos maus, mais do que tudo, e como pessoa exasperada pelo vazio e pela inutilidade da sua vida. ( $p$. 444)

\footnotetext{
96 Em substituição à admiração inicial pela "Sonata a Kreuzer", veio a decepção. Thcékhov, certa vez, chegou a dizer que, antes de tratar tal tema, Tolstói deveria ter lido dois ou três livros especializados.

Nas obras de Tchékhov, a insolubilidade dos problemas existenciais, o que é a pedra de toque do sofrimento das personagens, afeta ambos os sexos, embora, por força da diferença social, fisiológica e psicológica, as mulheres enfrentam situações mais complexas, em comparação com os homens.
} 
Na opinião de Bitsíli ${ }^{97}$, o vergonhoso desamparo de Nikolai Stepánovitch, incapaz de ajudar Kátia, não obstante a sua rica experiência pedagógica, torna-os estranhos um para o outro a tal ponto, que não Ihes resta mais do que bater a cabeça na parede; a fenda no diálogo dos dois reflete a total incompreensão mútua, e Kátia vai-se, amargamente decepcionada com o seu padrasto e amigo.

Para a análise da figura de Kátia, é preciso deixar de lado as apreciações do narrador, empregando apenas os factos da vida dela, referidos por ele, e examinar como os meios artísticos transformam tais factos. Recordemos brevemente a biografia de Kátia.

Antes de mais nada, a sua vida não repete nem um pouquinho a "composição talentosamente feita" do professor. Desde a infância, persegue-a uma série de contínuas perdas do que é o mais caro que uma pessoa possa ter. Aos sete anos, perde os genitores, fica órfã e vai para uma família alheia, na qual cresce como uma criança doentia e não muito feliz, desprovida da atenção de quase todos. Em outra cidade para os estudos, ela inesperadamente apaixona-se pelo teatro; em casa, nas férias, encontra total desinteresse por ela, pela sua vida e pela sua paixão. Os de casa ignoram-na; apenas o tutor Nikolai Stepánovitch escutaa, por pena, na meia hora que lhe dá. Ao término dos estudos, ela torna-se atriz e vai, com uma companhia teatral, para Ufá. A paixão pelo teatro, que se apoderara dela, traz à sua vida "tediosa" algo radiante, inspirado e verdadeiro. Tem início um breve período feliz, de quatro anos, na sua vida triste. Ela faz aquilo de que gosta, viaja e constrói planos para a vida.

Em seguida, tudo vem abaixo; Kátia decepciona-se com os

${ }^{97}$ A.TCHÉKHOV. Pro et contra, 2010, p.586. 
seus colegas atores, com o seu próprio talento, e perde um amor. E, por fim, tendo perdido o recém-nascido, tenta o suicídio. É salva. Sozinha, sem ajuda nem comiseração da parte de outrem, ela volta para Moscou e aluga apartamento, perto de Nikolai Stepánovitch. O seu destino repete-se em muito não somente na Nina Zariétchnaia de "A gaivota" e, de modo surpreendente, numa mulher real, amiga próxima de Tchékhov, uma beldade que sonhava com o teatro, Lika Mizínova, que naquele mesmo ano de 1889 entrara na vida dele e se cartearia com ele por longos anos.

As sua's relações pessoais não foram simples: a apaixonada Lika e o "semi-apaixonado" Tchékhov, brincalhão e irónico, que não prometia nada. Torturada por essa indefinição, ela parte, em 1894, para Paris com o conhecido escritor Ignátii Potápenko, cedendo ao seu amor e promessa de deixar a família. Ele, no entanto, abandona não a esposa, mas a ela, Lika. Ela dá à luz uma criança, que morreria logo depois. E do mesmo modo como a Kátia prevista para ela, Lika vê-se na mais desesperadora situação, e vem-Ihe à cabeça a ideia do suicídio.

O passado de Kátia é trágico, o presente é ainda mais monótono do que 0 de Nikolai Stepánovitch, com menos acontecimentos, obrigações e pessoas, e o futuro é incerto e nem a preocupa; ela não constrói já nenhuns planos, e nada a interessa. 0 vestido negro torna-se, como já assinalámos, um pormenor simbólico, indicador da falta de futuro (e também dela associador à personagem-doutoranda, também vestido de preto). O tempo pára para ela, que parece mergulhar na penosa neblina uniforme da vida semi-desperta e semi-dormente, diluída com a leitura de romances amenos e o desperdício irrefletido do dinheiro paterno e de encontros vespertinos com duas pessoas do seu agrado. $O$ seu 
estado é semelhante à insónia em que vive o professor. A característica básica e definidora da sua vida é a preguiça:

Atualmente, Kátia vive a meia versta de minha casa. Alugou um apartamento de cinco peças, instalando-se com bastante conforto e com o gosto que lhe é inerente. Se alguém se propusesse representar o ambiente em sua casa, o estado do espírito dominante no quadro seria a preguiça. Sofás macios e macios tamboretes para o corpo preguiçoso; tapetes para os pés preguiçosos; cores esmaecidas, lívidas, foscas, para a vista preguiçosa; para a alma preguiçosa, abundância nas paredes, de leques baratos e quadros insignificantes, em que o originalidade da composição predomina sobre o conteúdo, um excesso de mesinhas e prateleirinhas, abarrotadas de objetos completamente desnecessários e sem valor, trapos disformes em lugar de cortinas...Tudo isso, a par do temor às cores vivas, à simetria a aos espaços amplos, testemunha, além da preguiça de espírito, uma deformação do gosto natural. Katia passa dias inteiros deitada no sofá, lendo livros, na maioria romances e novelas. Sai de casa apenas uma vez, depois do meio-dia, para me ver. (123)

Essa única e tão minuciosa descrição de objetos no texto é admirável para o narrador. Já o autor sublinha a enumeração das muitas coisas e pormenores do interior, baratos e vulgares, e o vazio, incompletude, da vida interior de Kátia. Vem à lembrança semelhante interior de outra personagem de Tchékhov, Olga Dýmov, de "Ventoinha" .

Para além disso, ela está liberta das convenções aceitas pela sociedade, e, à diferença das típicas mulheres do seu tempo, como as "nulidades" Vária e Liza, o matrimónio não a interessa:

- E você está sempre deitada - digo-lhe, depois de um silência e tendo descansado um pouco. - Isso faz mal à saúde. Você deveria ocupar-se de alguma coisa. 
- Digo que deveria arranjar uma ocupação.

-Arranjar o quê? Uma mulher só pode ser operária ou atriz.

-E então? Se não pode ser operária, vá para o teatro.

Cala-se.

-Ou então se case - digo, meio gracejando.

-Não há com quem. E não há motivo.

-Não se pode viver assim.

-Sem marido? Grande coisa! Há homens à vontade, basta querer.

-Isso não é bonito, Kátia.

-O que não é bonito?

-Isso que você acabou de dizer. (131)

Família propriamente dita, ela não tinha, e família não representava nenhum valor para ela; é por isso que ela dá com tanta leviandade a Nikolai Stepánovitch o conselho de deixar a esposa e a filha e partir para algum lugar. Na sua opinião, a raiz dos problemas do padrasto está precisamente nelas, e é nelas que deita a culpa pela abalada saúde dele. Vária e Liza, por sua vez, odeiam-na e consideram "indecente" a relação dela com Nikolai Stepánovitch, por ela ser tão alheia ao mundo deles e desprezar tão declaradamente a ele e a elas. Preocupa especialmente a esposa o modo como os encontros dos dois parecerá aos olhos dos conhecidos. É possível que, sem o reconhecerem para si, elas sintam certa culpa pelo acontecido a Kátia, e isso vem sugerido por um pormenor. Na infância, Kátia achava graça no castigo, infligido a pessoas adultas e estudantes, chamado "pôr de joelhos". É provável que a ela própria tenham castigado assim mais de uma vez.

- Os estudantes brigam na universidade? -perguntava ela.

- Brigam, querida.

- E o senhor manda ficarem de joelhos?

- Mando.

Achava graça em que os estudantes brigassem e eu os mandasse ficar de joelhos, e ria. (118) 
Ofendida com o fato de Kátia ter chegado e não ido dizer os bons-dias aos de casa, Liza diz:

- Mamãe! - diz Lisa com censura. - Se ela não quer, que vá com Deus. Não vamos ficar de joelhos. (125)

Se a vida de Kátia houvesse tido outro rumo, ela, possivelmente, de menina "que gostava muito de falar" e rir, haver-se-ia, com o tempo, transformado numa "velhota faladeira e de riso fácil (127)), tal qual a criada Agacha, a quem o professor recorda com carinho. Ela poderia ter sido uma bela esposa e mãe, com a sua capacidade de diluir-se na pessoa amada. No príodo de breve felicidade, absorvida pelo amado e pelos planos deste, ela até lembra uma personagem muito distante dela, a Ólenka Plemiánnikova de «Queridinha».

As cartas que se seguiram eram igualmente magníficas, mas já apareciam nelas sinais de pontuação, desapareceram os erros gramaticais, e começaram a exalar forte cheiro masculino. Kátia passou a escrever-me que seria bom construir em alguma cidade do Volga um grande teatro, em base de sociedade anônima, e atrair para a empresa comerciantes ricos e armadores; as receitas seriam enormes, os atores teriam participação nos lucros...É possível que tudo isso seja realmente bom, mas tenho a impressão de que semelhantes projetos só podem provir duma cabeça masculina. (121)

No entanto, aos vinte e cinco anos, ela já perdera tudo na vida. E do mesmo modo como as recordações animam e dão cores à vida baça e tediosa de Nikolai Stepánovitch, tão-somente um único fio liga Kátia à vida viva, às emoções vivas, a um "deus do homem vivo": o próprio professor, tutor, quase pai, amigo chegado, a única pessoa no mundo que Ihe dava atenção, ainda que só de vez em quando, ainda que por pena e pelo sentimento de dever, em 
memória dum amigo falecido. A única pessoa que Ihe escrevia, ainda que cartas tediosas, mas escrevia, dava conselhos. A única pessoa de que Kátia gosta. Nikolai Stepánovitch fora e continua a ser para ela um herói, quase da escala antiga, semelhante a Hércules, tal como o professor recorda a si próprio. Kátia não possui mais ninguém nem nada.

Sem dúvida, como julga a maioria dos críticos, há determinado paralelo e determinada semelhança entre os dois. Isso é também apontado por um pormenor "fortuito":

Lembro-me também, ela gostava de vestir-se bem e de se perfumar. Nesse sentido, parecia-se comigo. Também eu gosto de roupas bonitas e de bons perfumes (118)

Um mesmo caminho, na vida, da esperança, inspiração, amor e do trabalho prazeroso à decepção, ruína e até a morte é percorrido por ambos; apenas Nikolai Stepánovitch o faz no decorrer de alguns decênios, e Kátia, impetuosamente, em três ou quatro anos. Nisso esgota-se, na nossa opinião, a semelhança entre os dois. Eles representam dois tipos psicológicos diferentes. Ele tem raciocínio lógico; ela, metafórico. A ela são verdadeiramente incompreensíveis a "filosofação" dele e a sua "ideia geral".

E em geral... eu não gosto dessas conversas sobre arte! continua nervosa. - Não gosto! E já banalizaram tanto, muito obrigada!

-Quem a banalizou?

-Uns a banalizaram com a bebedeira, os jornais, com o trato familiar, as pessoas inteligentes, com a filosofia.

- A filosofia não tem nada a ver com o caso.

- Tem, sim. Se alguém filosofa, isso quer dizer que não compreende. (150) 


\begin{abstract}
Eles dão um ao outro conselhos verdadeiramente inexeqüíveis nas condições em que encontram, e não correspondentes aos seus caracteres: assim, Kátia propõe a Nikolai Stepánovitch deixar a família e ir-se para algum lugar, e ele, por sua vez, sugere a ela procurar trabalho ou casar-se. Não se pode, porém, afirmar com certeza que entre os dois haja uma completa incompreensão. De vez em quando, eles caracterizam um ao outro com admirável exatidão:
\end{abstract}

-Tem um tom e umas maneiras de vítima. Isso não me agrada, minha amiga. Vocé mesma é culpada. (150)

Não tem sensibilidade, não tem ouvido para a arte. Esteve ocupado a vida inteira e não teve tempo de adquirir essa sensibilidade. (150)

Do texto não decorre que a Kátia incomode a falta de sentido da sua existência; ao contrário, conversas acerca disso aborrecemna, e ela simplesmente esquiva-se a conselhos. Apenas numa única cena nós observamos algo que sugere que ela reflita nesse tema, e isso de passagem, aliás. Também naquela, o reconhecimento da falta de talento é-lhe muito mais doloroso:

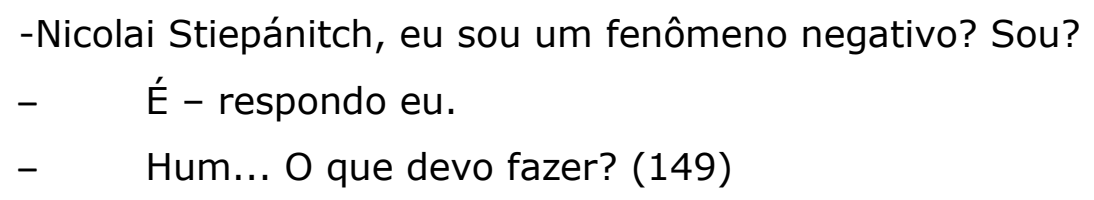

Discordamos radicalmente da opinião (Katáev, Linkov e outros), segundo a qual Kátia não compreende a dor do seu amigo e padrasto e não a sente, nem nota a sua doença. Inúmeros pormenores, ao contrário, indicam precisamente que ela a sente e 
nota.

Ela visita-o todos os dias e recebe-o em casa todas as noites. Seguindo-o, ela muda-se para a datcha e aluga casa nas proximidades; leva-o a passear todos os dias e passa todos os fins de tarde e começo da noite com ele. Esses são os únicos acontecimentos na vida dela. Cínica e desiludida, com que sentimento ela escuta os seus relatos da vida passada!

Como isso não se parece com aquelas meias horas, em que ela, outrora, o obrigava a escutá-la! Nós já assinalámos o que significa um símbolo tão essencial como uma mesa de trabalho, e o facto de Kátia organizar na sua própria casa, no seu espaço pessoal, um lugar de trabalho para ele, diz bem da confiança ilimitada que ele via nos seus olhos infantis.

Ela oferece-Ihe todo o seu dinheiro, isto é, em essência, a única coisa que pode oferecer-lhe. Tal atitude lembra-nos a decepção, que Nikolai Stepánovitch experimenta em relação aos próprios filhos, e as suas censuras a eles, que não querem notar a sua humilhação diante da pobreza. Cria-se a nítida impressão de que toda a vida de Kátia se encerra em Nikolai Stepánovitch; ela não consegue passar nem um dia sem ele, os seus pensamentos são nele, e tudo o que faz, é por ele. Ele é a "ideia geral" dela, o seu "estojo" .

E a progressiva moléstia do professor é o que não dá sossego a Kátia, mudando o seu comportamento, estado de espírito e tom da voz. A primeira cena com Kátia termina com o seguinte diálogo: 
severidade da cabeça aos pés e diz, magoada:

-Está emagrecendo sempre! Por que não se trata? Vou procurar Sierguiéi Fiódorovitch e pedir que examine.

- $\quad$ Não precisa, Kátia.

- Não compreendo como a sua família não percebe! Boa gente, pode-se dizer. (124)

Na cena seguinte (na casa de Kátia), esta estava com preguiça, a falar mal dos outros e a rir, e, de repente, a conversa passa à doença de Nikolai Stepánovitch e o estado dela muda repentinamente. Não podemos deixar de assinalar este pequeno pormenor:

- O que tem? Está doente?

- Sim, um pouquinho

- E não se trata... - acrescenta Kátia, taciturna. (141)

A doença do professor é o que torna a cínica e a tudo indiferente Kátia "severa e sombria" e o que é verdadeiramente sério para ela na sua vida desprovida de objetivos.

Pelo convívio diário com o padrasto e pela sua concentração nele, ela não pode deixar de notar o desenvolvimento da doença dele. Por que, então, julga a crítica unanimemente que Kátia não o escuta e não o compreende?

Kátia não está em condições de compenetrar-se dos sentimentos e pensamentos do padrasto; é inacessível a ela, a realidade de outra pessoa. (...) Nikolai Stepánovitch fala duas vezes a ela, a pessoa mais cara a ele, da sua morte e, em ambas as vezes, não encontra simpatia. Quando ela the oferece dinheiro, ele responde: "O teu dinheiro, agora, é completamente inútil para mim". As palavras "agora, é completamente inútil para mim", parece, poderiam pelo menos inquietar Kátia, que sabe da grave moléstia de Nikolai Stepánovitch. Mas ela não consegue ouvir o que Ihe dizem, e ofende-se, de modo completamente 
despropositado: "Eu compreendo-o... Tomar dinheiro emprestado duma pessoa como eu... uma atriz retirada..." Kátia emprega a forma estereotipada "Eu compreendo-о" ("Я вас понимаю"), mas o facto é que não compreende. Sentimentos "de escravo" ("рабские") excluem qualquer contacto verdadeiramente humano. ${ }^{98}$

Voltemos ao episódio, referido pelo crítico, a chegada inesperada de Kátia numa noite dos pardais.

Mas eis que range o portão do jardim, alguém se esgueira ali e, quebrando um ramo de uma das arvorezinhas esquálidas, bate com ele cautelosamente na janela.

- Nicolai Stipánitch! - ouço um murmúrio. - Nicolai Stiepánitch!

Abro a janela e tenho a impressão de estar vendo um sonho: embaixo, apertada contra a parede, está uma mulher de negro, fortemente iluminada pelo luar, e dirige para mim os olhos grandes. Tem o rosto pálido, severo e fantástico devido ao luar, como que de mármore, treme-lhe o queixo.

- Sou eu... - diz ela. - Eu... Kátia!

Ao luar, todos os olhos de mulher parecem grandes e negros, as pessoas, mais altas e mais pálidas, e provavelmente por isso não a reconheci no primeiro instante.

- O que você quer?

- Desculpe - diz ela. - De repente, não sei por quê, tive um sentimento intoleravelmente penoso... Não pude suportar e vim para cá... Havia luz na sua janela, e..., eu resolvi chamá-lo... Desculpe... Ah, se o senhor soubesse como era penoso o que senti! O que está fazendo agora?

- Nada... Insônia.

- $\quad$ - Tive não sei que pressentimento. Aliás, é ninharia.

As suas sobrancelhas se levantam, brilham-lhe os olhos de lágrimas, e todo o seu rosto se ilumina, como que por uma luz, por uma expressão conhecida, há muito não vista, de confiança.

${ }^{98}$ V.LINKOV, Moscou, 1982, p.64. 
- $\quad$ Nicolai Stiepánitch! - diz ela súplice, estendendo para mim ambas as mãos. - Meu querido, peço-lhe... imploro... Se não despreza a minha amizade e o meu respeito pelo senhor, aceda ao meu pedido!

- $\quad$ O que é?

- $\quad$ Aceite dinheiro de mim!

- Ora, o que inventou! Para que preciso do seu dinheiro?

- O senhor vai tratar-se em alguma parte... O senhor precisa tratar-se. Vai aceitar? Sim? Meu querido, sim?

Fita avidamente o meu rosto e repete:

- Sim? Vai acertar?

- Não, minha amiga, não aceitarei...- digo eu. Obrigado.

Volta-me as costas e baixa a cabeça. Provavelmente, expressei a minha recusa num tom que não admitia mais conversas a respeito de dinheiro.

- Vá para casa dormir - digo. - Vamos ver-nos amanhã.

- Desculpe... - diz ela, baixando a voz toda uma oitava. -

Eu compreendo o senhor... Ficar devendo a uma pessoa como eu... uma atriz aposentada... Bem, adeus...

E ela se afasta com tamanha pressa que não consigo sequer dizer-Ihe também o meu adeus. (155-156)

Na tradução brasileira, infelizmente, omitiu-se um dos elementos mais importantes, que muda todo o quadro do que está a ocorrer (em letras gordas):

-- Поезжай домой спать,-- говорю я.-- Завтра увидимся. [Vai para casa dormir, - digo-lhe eu —. Amanhã nos veremos].

-- Значит, вы не считаете меня своим другом? -спрашивает она уныло. [Quer dizer que não me considera sua amiga? - pergunta ela pesarosamente.]

-- Я этого не говорю. Но деньги твои теперь для меня бесполезны. [Não é isso o que eu digo. Mas o teu dinheiro, agora, é inútil para mim.]

-- Извините...-- говорит она, понизив голос на целую октаву. 
[Desculpe, - diz ela, baixando... (...). ${ }^{99}$

À diferença de Nikolai Stepánovitch, que vai para junto de Kátia, fugindo a uma condição insuportável, para que o escutem e para estar na companhia duma pessoa simpática a ele, Kátia procura-o por ele próprio e por maus pressentimentos, para certificar-se de que esteja tudo em ordem com ele. A inquietação não a abandona. Tendo padecido tantas perdas, agitada e assustada, ela tenta afugentar o pensamento de que a espera mais uma, a perda do seu único ente querido. Ela está pálida, e o queixo treme-lhe. Tendo verificado que ele está vivo, que está tudo em ordem e que tudo não passa duma insónia, Kátia volta a ser a de antes, quase feliz como uma criança. E precisamente então:

As suas sobrancelhas se levantam, brilham-lhe os olhos de lágrimas, e todo o seu rosto se ilumina, como que por uma luz, por uma expressão conhecida, há muito não vista, de confiança. (155)

Que acontece em seguida? Kátia oferece dinheiro, Nikolai Stepánovitch não o aceita e alude a uma morte próxima; Kátia "ofendese" e vai-se. Dinheiro é tudo o que poderia oferecer, contanto que isso pudesse melhorar o mais importante para ela: o estado e a saúde dele; e ela está disposta a entregar tudo isso e até implora que ele o aceite. Poderia Kátia pensar seriamente que Nikolai Stepánovitch a despreze como atriz retirada? Dificilmente.

Em compensação, logo após a alusão de Nikolai Stepánovitch acerca da inutilidade do dinheiro para ele naquele momento, a voz de Kátia "baixa uma oitava inteira". Um importantíssimo pormenor musical simplesmente "grita": Kátia compreendera tudo. Ela ouvira precisamente o que mais temia, e o cérebro recusa-se a aceitá-lo. Tal qual a imensa maioria das personagens de Tchékhov, incapazes de confessar o mais

\footnotetext{
${ }^{99}$ A.TCHÉKHOV, Moscou,1977, p.303-304.
} 
importante a si próprias e aos outros, Kátia está aterrorizada e, como se se defendesse, diz a primeira tolice que lhe vem à cabeça. E foge precipitadamente. A fuga apresenta-se como uma ilusão de salvamento.

A cena seguinte é em Khárkov.

Uma batida leve na porta. Alguém precisa de mim.

- Quem está aí? Entre!

Abre-se a porta e, surpreso, dou um passo para trás e apressome a juntar as abas do roupão. Quem está diante de mim é Katía.

- Bom dia - diz ela, respirando pesado, em consequência da escada. - Não me esperava? Também eu... também eu vim para cá.

Senta-se e prossegue, gaguejando e sem me olhar:

- Por que não me diz bom-dia? Eu também cheguei...hoje... Soube que o senhoe estava neste hotel e vim vê-lo.

- Estou muito contente de ver você - digo, dando de ombros - , mas estou surpreendido... Você como que caiu do céu. Para que está aqui?

- Eu? Assim... simplesmente, peguei e vim.

Silêncio. De repente, ela se ergue num arranco e caminha na minha direção.

- Nicolai Stiepánitch! - diz, empalidecendo e apertando as mãos sobre o peito - Nicolai Stiepánitch! Não passo mais viver assim! Não posso! Pelo amor do Deus verdadeiro, diga-me o quanto antes, já: o que devo fazer?

- O que posso dizer? - fico perplexo. - Não posso nada.

- Mas fale, eu Ihe imploro! - continua ela, ofegante, o corpo todo trêmulo. - Juro-Ihe que não posso mais viver assim! Não tenho mais forças!

Cai sobre uma cadeira e põe-se a soluçar. Jogou a cabeça para trás, estrala os dedos, bate os pés; o chapeuzinho caiu-lhe da cabeça e balança-se sobre o elástico, o penteado está desfeito.

- Ajude-me! Ajude-me! - implora. - Eu não posso mais!

Tira da sua bolsinha de viagem um lenço e, com ele, algumas cartas que the caem dos joelhos para o chão. Levanto-as, 
reconheço numa delas a letra de Mikhail Fiòdorovitch e, sem querrer, leio o fragmento de uma palavra: "apoixonad..."

- Não posso dizer nada a você, Katía.

- Ajude-me! - soluça ela, agarrando-me a mão e beijando-a. - O senhor é meu pai, o meu único amigo! É inteligente, culto, viveu muito! Foi professor! Diga-me: o que devo fazer?

- Pela minha consciência, Katia: não sei...

Estou perplexo, confuso, comovido por aqueles soluços, e mal me seguro sobre as pernas.

- Vamos almoçar, Kátía - digo, sorrindo tenso. - Chega de chorar!

E logo acrescento, a voz caída:

- Em breve, deixarei de existir, Katía...

- Ao menos uma palavra, ao menos uma palavra! - chora ela, estendendo-me os braços. - O que fazer?

- Que mulher esquisita, realmente... - balbucio. - Não compreendo! Tão inteligente, mas num átimo - aí está! - caiu um pranto...

Segue-se um silêncio. Katía ajeita o penteado, põe o chapéu, depois amassa as cartas e enfia-as na bolsinha - e tudo isso em silêncio, sem se apressar. Tem o rosto, o peito e as luvas molhados de lágrimas, mas a expressão do seu rosto já é seca, severa... Olhando-a, tenho vergonha de ser mais feliz que ela. Foi somente pouco antes da morte, no ocaso dos meus dias, que notei em mim a ausência daquilo que os meus colegas filósofos denominam uma ideia geral, mas a alma dessa infeliz não conhece e não há de conhecer abrigo a vida toda, toda!

- Vamos almoçar, Katía - digo.

- Não, obrigada - responde ela com frieza.

Mais um minuto de silêncio.

- Não gosto de Khárkov - digo. - Há muita cor cinza. Uma cidade cinzenta.

- Sim, realmente... É feia... Vou passar pouco tempo aqui... Estou de passagem. Partirei hoje mesmo.

- Para onde?

- Para a Criméia...isto é, para o Cáucaso. 
- Bem, por muito tempo?

- Não sei.

Kátía levanta-se e, tendo sorrido com frieza, estende-me a mão sem me olhar.

Tenho vontade de perguntar: "Quer dizer que não virá ao meu enterro?" Mas ela não me olha, tem a mão fria, como que alheia. Acompanho-a calado pelo corredor comprido, sem olhar para trás. Sabe que a sigo com olhos, e, provavelmente, voltar-se-á na curva.

Não, não se voltou. O seu vestido negro apareceu pela útima vez, não se ouviram mais os seus passos... Adeus, meu tesouro! $(161)$

Segundo a opinião unânime da crítica, Kátia chega a Khárkov com a esperança de que Nikolai Stepánovitch lhe ensinará como viver, porquanto a sua vida se tornara insuportável pela falta de sentido. Mas ele não tem nada por oferecer-lhe, a não ser um "vamos desjejuar" ("давай завтракать"). É nisso que consiste o tédio de toda a história (Katáev).

Que acontece, a nosso ver, no último encontro dos dois? Com a partida de Nikolai Stepánovitch, quando Kátia não tem a possibilidade de vê-lo diariamente, a angústia dela e os maus pressentimentos aumentam muito. Parece mais natural que ela, tal como na "noite dos pardais", se tenha arrancado do seu lugar e corrido para ele, indo para outra cidade para dissipar a inquietação, tranqüilizar-se e certificar-se de que com ele estava tudo certo, e não para obter urgentemente um conselho sobre como tornar a sua vida consciente, sensata. E que vê ela dessa vez?

Nikolai Stepánovitch, no ambiente estranho dum hotel, conta com indiferença o tempo que Ihe resta; está apático, à espera da morte; ademais, começa-Ihe um tique nervoso na face; ele está a morrer. É nesse estado que Kátia o encontra.

E então, diante do aspecto dele, é que lhe vem a histeria. As personagens de Tchékhov raramente dizem o que verdadeiramente pensam, e Kátia não é exceção. O seu grito é uma súplica de consolo. 
Assim grita uma pessoa de medo, sem saber exatamente o que está a gritar: "Socorro! Que devo fazer?!" É Nikolai Stepánovitch, cujas reflexões num balanço da vida Kátia interrompe, que acha que ela sofre do mesmo que ele: na vida dela, não haveria uma ideia geral. Parece-nos que, contrariamente à opinião dos críticos, uma "ideia geral" é a última coisa que a possa preocupar naquele momento. Ela compreende o que se passa: logo estará cara a cara com a sua inútil vida. E tudo o que ela quer - que ele a tranquilize e diga que com ele está tudo bem, - eis aí a "uma palavra" que ela espera dele e a ele implora. No acesso de histeria, ela de repente ouve claramente, em resposta à sua súplica de ajuda, o que é o mais horrível de tudo para ela, e já não uma indireta, mas uma afirmação direta: em breve, ele já não estaria entre os vivos. E como se não houvesse entendido imediatamente a frase dele, ela ainda grita e estendeIhe a mão, mas o terrível significado das palavras chega-lhe aos poucos. Kátia ali chegara com uma frágil esperança, e ele privara-a dela.

E bruscamente, depois da tomada de consciência do irreparável, tudo muda; sobrevém o silêncio, o tempo para, o rosto torna-se já seco, grave... Esse é o ápice do sofrimento; ela é já incapaz até de chorar. Tudo duma vez perde o sentido. Ela não consegue olhar para ele, a conversa torna-se sem sentido, e depois é só o frio, a mão fria como que dum desconhecido, o vestido negro. Como se também para Kátia a vida houvesse acabado.

Katáev, num dos seus livros ${ }^{100}$, compara "Uma história enfadonha" com "Fausto", de Goethe, e traça uma correspondência entre os pares Fausto-Wagner e Nikolai Stepánovitch-Piotr Ignátievitch.

Kubássov ${ }^{101}$ foi mais longe, com a observação da semelhança entre Kátia e Margarita e entre Mikhail Fiódorovitch e Mefistófeles. Tendo

\footnotetext{
100 KATÁEV, V. B. Literaturnye svjazi Tchekhova (Contactos literários de Tchékhov). Moscou, Ed. da Univ. Estatal de Moscou,1989.

101 KUBÁSSOV, A. Proza A. P. Tchekhova. Iskusstvo stilizacii (A prosa de A. P. Tchékhova. Arte da estilização). Ekaterinburg, 1998
} 
ressaltado que o papel do último no texto permanece obscuro, ele dá a sua interpretação à figura da personagem. Ele observa, antes de mais nada, que as iniciais do nome e do patronímico (M. F.) não foram escolhidas ao acaso, mas apontam para determinado protótipo literário, à semelhança do nome e do apelido de Dmítri Gúrov "A dama do cachorrinho") por analogia como Don Guán (Don Juan, em russo). Uma semântica complementar provém de características da aparência (cabelos grisalhos e sobrancelhas negras), que se encontrariam na figura de outro Mefistófeles, o monge negro de "O monge negro". Kubássov analisa o léxico da personagem, no qual são recorrentes algumas réplicas sugeridoras da origem "infernal", como, por exemplo, "адски холодно" (um frio dos infernos) е "к чёрту" (o diabo que o carregue), e acrescenta que, por ironia, essa personagem se dirige a deus com mais frequência do que as outras ( $A i$, meu Deus!, Deus me livre etc ), e assinala o cinismo de Mikhail Fiódorovitch, principalmente quando se fala de outros membros da Igreja, o que, na opinião do estudioso, fala duma genealogia literária, dum oculto parentesco com Mefistófeles.

Nós concordamos em muito com as conclusões de Kubássov, mas ele deixou escapar dois pormenores substanciais, que não apenas complementam a figura da personagem, senão também a modificam.

O primeiro é que a personagem não é simplesmente um colega de universidade, mas um filólogo; mais do que isso:

Pertence a uma antiga e nobre família, bastante feliz e talentosa, que desempenhou um papel apreciável na historia da nossa literatura e da nossa instrução. (134)

E isso significa que, desde a infância, Mikhail Fiódorovitch vive num meio, em que se fala de literatura, e num mundo de personagens literárias, provando em si as personalidades delas, como quem prove uma camisa a ver se ela the serve.

Ele cita Liérmontov, o seu modo de falar lembra a Nikolai 
Stepánovitch o tom dos coveiros de Shakespeare, e, em relação a isso, podemos lembrar mais um filólogo de Tchékhov, que também opera com nomes de escritores e de personagens literárias e prova em si os papéis delas: Laiévski ("Duelo").

O segundo pormenor é um daqueles "fortuitos": barbeado.

E, de fato, um instante, depois, entra meu colega, o filólogo Mikhail Fiódorovitch, alto, bem proporcionado, de uns cinquenta anos, com cabelos densos e grisalhos, sobrancelhas negras e rosto barbeado. (134)

À diferença de outras características exteriores, dadas no seu retrato, das sobrancelhas negras e dos cabelos grisalhos, o seu "estar barbeado" não o define de modo nenhum, mas, em compensação, liga-o diretamente a outra personagem "barbeado", o ator-amante de Kátia.

Com a carta, vinha a fotografia dum jovem de rosto barbeado... (121)

Para além de ambos estarem relacionados com Kátia, um estivera apaixonado por ela no passado, o outro no presente; os dois são pessoas da mesma têmpera, naturezas artísticas, criativas. Talvez seja precisamente essa característica o que atrai Kátia. E o paralelo com o ator, estabelecido pelo pormenor, ressalta que Mikhail Fiódorovitch apenas desempenha o papel de Mesfistófeles, identificando-se com ele.

A impressão de ele agir como ator e fazer cena para os outros é reforçada pelo jogo de paciência, a que se dedica. Agradam-Ihe tanto o papel quanto a atenção de Kátia. Pode notar-se que eles se compreendem maravilhosamente.

Katia acompanha-o, com atenção as suas jogadas e ajuda-o mais com mímica do que com palavras. (137)

Infunde muito respeito a Kátia o seu cinismo, os seus chistes, a 
elegante dignidade afetada, o artisticismo. No entanto, de tempos em tempos, por influência do amor, que ele é incapaz de controlar, a máscara cai-lhe:

Quando ele recebe de Kátia um copo ou ouve uma observação, ou se acompanha com o olhar, se ela sai por uns instantes do quarto, a fim de buscar qualquer coisa, noto nos olhos dele algo humilde e puro, algo que reza. (136)

E, quer-nos parecer, precisamente nos momentos em que ele sai do papel, ele, do modo mais natural, não na qualidade de ironia, emprega frases como "Graças a deus!"e assim por diante. E, quanto mais forte se torna o seu amor a Kátia, tanto menos ele lembra Mefistófeles.

Há muito tempo já que Mikhail Fiódorovitch devia ter viajado para o estrangeiro, mas ele adia a partida cada semana. Nos últimos tempos, aconteceram com ele certas modificações: parece mais acabado, passou a embriagar-se com vinho, o que antes nunca Ihe acontecera, e as suas sobrancelhas negras estão começando a branquear. Quando a nossa carruagem pára junto ao portão, ele não esconde sua alegria e impaciência. Agitandose, ajuda Kátia e a mim a descer do carro, apressa-se a fazer perguntas, ri, esfrega as mãos, em que há de humildade, puro, de reza, que eu já notara apenas em seu olhar, espraia-se agora por todo o seu rosto. Alegra-se e, ao mesmo tempo, envergonhase da sua alegria, envergonha-se desse costume de ir à casa de Kátia todas as noites, e julga necessário motivar a sua vinda com algum contrassenso evidente, no gênero de "Estava passando por aqui, a serviço, e pensei: vamos entrar um instantinho". (151)

À medida que a natureza demoníaca com tom permanentemente brincalhão e mistura de filosofia com chalaça, como no caso dos coveiros de Shakespeare, vai cedendo o papel ao apaixonado comum, o interesse 
de Kátia diminui. A carta amassada com um pedacinho da palavra "apaix.", uma franca confissão em que a chalaça é impossível, é uma clara derrota de Mikhail Fiódorovitch.

E, se ele nisso se revela apenas um ator no papel do "espírito impuro", o Diabo, então outra personagem às ocultas, gradualmente, passa a personificar esse espírito impuro. É Aleksandr Adólfovitch Hnekker. Simultaneamente a "Uma história enfadonha", em 1889, Tchékhov escrevia a peça "O silvano", que, posteriormente, seria reelaborada e se tornaria "Tio Vánia", cujas personagens, tal como Mikhail Fiódorovitch, provam, em si e em outras personagens, diversas máscaras literárias. Assim, o título "Silvano", para alguma decepção do público, que esperava ver, no palco, uma figura das lendas do folclore, revela-se tãosomente a alcunha duma personagem.

Sem entrarmos na análise dos paralelos entre os dois textos, e tais paralelos existem, queremos assinalar que para nós o importante é o facto de que, no período de escrita de "Uma história enfadonha", era grande o interesse de Tchékhov por mitologia e, principalmente, no presente caso, pelo folclore e que tal interesse se materializa nas figuras das personagens e nos papéis desempenhados por elas.

Como escreve M. Odiésskaia, no estudo da peça:

A figura folclórica do silvano é ambivalente: ela, por um lado, está relacionada com as forças das trevas, infernais e hostis ao homem e, por outro, o silvano recebeu frequentemente traços cómicos e constitui uma das personagens dos contos natalinos. ${ }^{102}$

Recordemos o retrato de Hnekker:

É um jovem louro, que não tem mais de trinta anos, de estatura média, muito corpulento, de ombros largos, com suíças ruivas

102 M.ODESSKAJA. Tchékhov i problema ideala, Moscou, 2011, p. 167 
junto às orelhas e bigodinho pintado, que dá ao seu rosto cheio e liso um quê de brinquedo. Veste paletó muito curto, colete colorido, calças de xadrez graúdo, muito largas em cima e muito estreitas embaixo, e usa sapatos amarelos, sem salto. Tem olhos esbugalhados, de lagosta, a gravata lembra pescoço de lagosta e até, parece-me, todo esse moco exala um cheiro de sopa de lagosta. (126)

Nós já assinalámos, no capítulo dedicado à simbologia da gama cromática da sua aparência e traje, a sua associação, no nível dos pormenores simbólicos, pela cor ruiva das suas suíças, ao mercador ruivo e ao samovar de cobre deste, e também o facto de que o colorido do seu traje simboliza alheamento em relação ao mundo estimado e caro ao professor, do que este fala sem rodeios, chamando a Hnekker "corpos estranhas", um ser sem nada em comum com os outros e até o compara a um "zulu". Para além disso, no folclore russo, a cor ruiva frequentemente associa-se a vigaristas e embusteiros. ${ }^{103}$ Propp supõe que o epíteto "de cobre"; (por exemplo, Медный лоб - Fronte de cobre), frequentemente empregado em relação aos demónios da floresta, como Silvano e Silen, nos contos de fadas, pode estar relacionado precisamente com a cor ruiva do cobre ${ }^{104}$ (o que mais uma vez leva de volta ao mercador e ao seu samovar).

Um traço característico do silvano, no folclore russo, era a capacidade de deixar confusa a cabeça às pessoas, depois de que elas caíam inteiramente no seu poder. Assim sob o poder de Hnekker caem Liza, Vária e, para a admiração do professor, muitos outros.

\footnotetext{
${ }^{103}$ Por exemplo, no conto recolhido por A. Afanássiev e intitulado "C рыжим, да красным не связывайся" (Com o ruivo e o vermelho não te metas).
}

Disponível em: http://hyaenidae.narod.ru/story5/339.html.

${ }^{104}$ V. PROPP. Istoricheskie korni volshebnoj skazki, Moscou, Labirint, 2000, p.133.

Disponível em: https://www.e-reading.club/book.php?book=46789 
...emite juízos sobre música, com grande autoridade, e, eu notei, os demais concordam com ele de bom grado. (126)

$\mathrm{E}$, o que é o mais interessante, em muitos contos de fadas russos, o silvano rouba a filha da personagem, para com ela casar-se. ${ }^{105}$

Para além disso, a roupa vistosa, colorida e grotesca suscita associação com o bufão, que aparece frequentemente na figura dum ser mesquinho e maldodo ("шут" - bobo, histrião, bufão - é um dos eufemismos para "Diabo").

Os demónios assumem, nas crendices, o aspecto de animais do velho culto: bodes, lobos, cães, corvos, serpentes etc. Julgava-se que, no todo, eles tivessem aparência antropomorfa, mas com o acréscimo de alguns fantásticos ou monstruosos. Esses eram, sobretudo, cornos e rabo ou pernas ou patas de bode; às vezes, pelagem ou focinho de porco, unhas, asas de morcego e assim por diante. Embora aos demónios houvesse sido dado o mundo todo para as suas andanças, eles, ainda assim, tinham os seus sítios preferidos para domicíklio permanente. De mais bom grado estabelecem-se em lugares onde bosques espessos sejam cortados por faixas contínuas de pântanos inacessíveis, nunca pisados por pés humanos. Ali, nos tremedais ou lagos cobertos de vegetação, onde ainda se conservam camadas de terra misturada a raízes de alga entrelaçadas, o pé humano afunda rapidamente... Não é aqui que oculta a força maligna do diabo?... Isso refletiu-se nos ditados russos "В тихом омуте черти водятся" ("No pego calmo escondem-se demónios", com o sentido de "Guarda-te do homem que não fala e do cão que não ladra"), "Было бы болото, а черти будут" (Sempre haverá mãos ociosas para fazerem o trabalho do diabo. Haja cibo no pombal, que pombas não faltarão. $)^{106}$

105 Conto" Silvano", na redação de A. Afanássiev.

Disponível em: http://hyaenidae.narod.ru/story5/333.html.

106 V.ARTEMOV Mify i predanija slavjan.

Disponível em: https://www.e-reading.club/bookreader.php/1034505/Artemov_- 
Na sua figura, há algo de brinquedo, isto é, artificial, não humano, e ninguém, no fundo, sabe o que quer que seja dele:

Ninguém de minha família sabe qual a sua origem, onde estudou e quais os seus meios de vida.(126)

Fazendo um balanço, temos, diante de nós, um ser ruivasco desagradável, de outro mundo, de que não se sabe nada, que subjuga pessoas, que possui traços exteriores, associados a um animal (caranguejo), que exala um cheiro a rio e pântano e rapta a filha duma personagem para casar-se com ela. Claramente, Hnekker apresenta-se na figura do espírito impuro do folclore, seja dum silvano, seja dum demónio, não dotado da pujança diabólica de Mefistófeles, é verdade, mas semeador do mal e do embuste em torno de si. E não foi por acaso que Tchékhov lhe deu a nacionalidade alemã.

Pode recordar-se o conto "O sapateiro e o espírito impuro", escrito em 1888, um ano antes de "Uma história enfadonha"; nele, apesar do tom irónico, também se encontram motivos de "Fausto" e um encomendador de botas, com um apelido alemão difícil de pronunciar, aparece em sonho a um sapateiro, na forma do Diabo, e compra a alma da personagem por bens mundanos.

Nas obras de Tchékhov, há muitas personagens alemãs, a começar dos primeiros, humorísticos, nos quais se aproveitam as particularidades do caráter nacional e os chavões literários e nos quais se tornam procedimentos cómicos os apelidos engraçados ${ }^{107}$, a pronúncia errada de palavras russas ou a inclusão da fala alemã na russa. Nos contos mais

_Mify_i_predaniya_slavyan.html

107 No conto "Isto e aquilo", da primeira fase, encontram-se os apelidos Klopson (russo клоп "percevejo" + alemão son - "filho": "filho dum percevejo") e Verfluchtenschwein (literalmente: проклятая свинья - "porco maldito"). 
tardios, diminui o efeito cómico, até quase desaparece, mas permanece a contraposição das particularidades de caráter de alemães e russos, que leva as personagens à não aceitação um do outro, à incompreensão ou conflito; dum lado, despreocupação, largueza, espontaneidade, emotividade; do outro, seriedade e ponderação, concentração, parcimónia e previdência, falta de autoanálise, estreiteza de vistas (von Koren de "Duelo", von Dideritz de "A dama do cachorrinho" e outros).

Precisamente esses traços, "alemães", encontram-se, em medida cabal, no chefe do serviço de necropsia de Nikolai Stepánovitch, o russo Piotr Ignátievitch, pessoa modesta e laboriosa mas limitada e desprovida de talento, que, em quaisquer situações graves e excepcionais:

...continuando calmamente a olhar em seu microscópio, o olho entrecerrado. (110)

Pela sua afeição aos cientistas alemães, que tanto irrita o professor, e a falta de autoanálise estabelece-se, indubitavelmente, um paralelo com o alemão Hnekker:

Quando ele começa, como de costume, a exaltar os cientistas alemães, eu não brinco mais bonachão, como antes, mas balbucio taciturno:

- $\quad$ Esses seus alemães são uns burros...

Isso já se parece com o seguinte: duma feita, o falecido Professor Nikita Krilov banhava-se em companhia de Pirogov em Revel e, irritando-se com a água, que estava muito fria, xingou: "Alemães canalhas". (147)

Ele vive no seu mundo microscópico, usando a profissão como um meio de isolar-se de tudo o mais, e é partidário apenas das tradições da Medicina, tais quais, por exemplo, o uso de gravata branca. Semelhante personagem ainda se encontrará em páginas de obras de Tchékhov, e pode recordar-se, sobretudo, o professor Biélikov ("Homem no estojo"), figura, claro, mais exagerada mas, ainda assim, representativa do mesmo 
tipo humano. Tanto a Piotr Ignátievitch quanto a Biélikov suscita interesse tão-somente o que estiver relacionado com a sua atividade profissional; no primeiro caso, a Medicina; no segundo, a língua grega. Em ambos os casos, há uma alusão a um campo "morto" das suas atividades. Porquanto Piotr Ignátievitch realiza necropsias, o seu trabalho não está relacionado apenas com os preparados que ele confecciona, mas também com a preparação de cadáveres; o idioma grego, que Biélikov ensina, é uma língua "morta". A confiança inquebrantável dos dois nos seus princípios e a negação de quaisquer outros alheios, em Biélikov, suscitam tédio e medo às outras pessoas e, em Piotr Ignátievitch, "inspiram enfado a todos os presentes" (146).

Como assinalámos já, este segundo vem acompanhado, no texto, de epítetos simbólicos, como "cinzento", "tedioso" e "seco": chapéu cinzento, secos relatórios.

...não inventará a pólvora. Para a pólvora, é preciso ter imaginação, capacidade inventiva, espírito divinatório, e Piotr Ignátievich não possui nada no gênero. Em suma, não é um patrão em ciência, mas um operário. (110)

É assim que Nikolai Stepánovitch o caracteriza, repetindo duas vezes a palavra "pólvora". A correspondente palavra russa, "порох", está etimologicamente relacionada com "прах" (cinzas, restos mortais), isto é, "пыль" (рó, poeira) ${ }^{108}$, acrescentando mais um matiz à mediocridade (Recordemos: o relógio de Biélikov fica num estojo de camurça cinzenta.). Para além disso, nesse fragmento, há uma alusão a um conto de fadas de Tolstói, "O patrão e o empregado"109, cuja moral é que só se pode considerar gente aquele que for capaz de pensar e tomar decisões sem ajuda de ninguém.

Piotr Ignátievitch aparece duas vezes no texto, no primeiro

\footnotetext{
108 http://www.classes.ru/all-russian/russian-dictionary-Vasmer-term-10082.htm

${ }^{109}$ Disponível em: http://hobbitaniya.ru/tolstoyln/tolstoyln50.php
} 
capítulo, na universidade, e no quarto, na datcha, como que para contraste, em seguida ao aparecimento do vigia Nikolai, pessoa de natureza oposta à sua. É impossível não notar que o vigia é um homónimo da personagem principal, e o próprio narrador aponta tal facto. E que o nome escolhido, tão caro a Tchékhov, nome dum irmão que acabara de falecer, tenha sido dado a duas personagens duma só vez, é muito significativo e obriga-nos a prestar atenção a esse pormenor "fortuito" e ao paralelo entre os dois, realçado pelo autor. Que pode haver de comum entre os dois, o vigia Nikolai e o professor mundialmente famoso Nikolai Stepánovitch, entre um soldado e um general, um simples mujique e um intelectual?

Nós acreditamos que tal questão está diretamente relacionada com o tema principal da novela: o tema da existência humana individual no infinito fluxo geral da vida, da natureza, do tempo e do espaço, isto é, no cronótopo. E aqui, como no caso de Vária e Kátia, a união baseia-se na contraposição, nos pólos opostos da concepção de mundo.

$\mathrm{Na}$ memória fenomenal do vigia da universidade, retratado com simpatia irónica, as pessoas e os acontecimentos do passado transformam-se e adquirem traços heroicos, fantásticos, encontrados nas bylinas. E o léxico nas páginas, a ele dedicadas, possui precisamente esse matiz semântico: fantásticas, misteriosa, secreta, guardião, herança, sábios extraordinários, numerosos mártires, vítimas da ciência, lendas, fábulas, heróis.

No que conto, o bem sempre triunfa sobre o mal, o fraco vence o forte, o sábio o estúpido, o modesto o presunçoso, o jovem o velho. (108)

Portador de consciência histórica e mitológica, ele vive livremente na fluidez do tempo; o passado, para ele, está indissociavelmente ligado ao presente e ao futuro, as pessoas reais com as lendárias. E Nikolai Stepánovitch, para ele, é um dos heróis, de quem logo se teceriam 
lendas. Isso determina a sua veneração e a invariável forma de tratamento "Vossa Excelência". Ele não é inclinado a longas reflexões lógicas, mas, graças à sua experiência de vida e intuição, quase sempre acerta nas suas previsões:

...um cientista disfarçado em soldado. (109)

Quase todas as suas réplicas diretas contêm um léxico referente à natureza, e as descrições, que o caracterizam, referem-se ao amor; ele gosta do seu trabalho, da universidade, da Ciência, das histórias lendárias, dos estudantes e dos professores com sinceridade e um maravilhamento de criança; em suma, ele ama a sua vida:

Deixando-me entrar, funga e diz:

- Que frio, Vossa Excelência! (107)

Или же, если моя шуба мокрая, то:

- Дождик, ваше превосходительство! ${ }^{110}$

- Que um raio me fulmine aqui mesmo!(145)

...olhando-me com o êxtase de um apaixonado. (145)

Somente quem ama pode lembrar assim. (108)

É pouco para a sociedade instruída. Se ela amasse a ciência, os cientistas e os estudantes como Nicolai os ama, a sua literatura possuiria há muito sobre esse tema verdadeiras epopéias, lendas e hagiológios, que infelizmente ela não tem agora. (108)

Mais um pormenor não destituído de importância: as portas, que ele abre, são um sinal simbólico da ampliação do espaço:

a porta abre-se de par em par...corre na frente e abre todas as portas no meu caminho (107)

No nível do subtexto, essa encantadora personagem parece constituir um guardião místico não apenas de lendas, senão também da

\footnotetext{
${ }^{110}$ Omitido na tradução brasileira: Ou, se a minha peliça está molhada, então: - Uma chuvinha, Vossa Excelência!
} 
ligação do homem com as forças da natureza, do tempo e do espaço. Essa é precisamente a ligação, que em sessenta e dois anos (mais um importante pormenor: não são apenas homónimos, mas também coetâneos) um adquiriu e o outro perdeu. Aquela ligação, cuja falta sente vagamente Nikolai Stepánovitch, tentando compreendê-la, captá-la e revesti-la dos termos costumeiros e familiares à sua lógica, chamando-Ihe "ideia geral". No entanto, essa matéria sutil não é suscetível de pensamento racional, uma vez que se encontra algures no campo dos sentimentos, pressentimentos, da sabedoria natural e da intuição, enfim, de tudo o que possui em medida cabal o simples soldado, vigia da universidade.

Para além das personagens principais, há, na novela, mais três, que aparecem uma única vez, os que vêm à casa de Nikolai Stepánovitch visitá-lo: um colega, o doutorando e o estudante preguiçoso. Via de regra, a sua presença no texto credita-se pelos estudiosos à necessidade de mostrar o dia-a-dia do professor, um meio informal. A nós, porém, tal explicação parece insuficiente. Nós achamos que cada qual deles, à sua maneira, está inserido na estrutura e composição da obra.

O colega de universidade é o único que não recebe nenhuma característica pessoal; ele funde-se completamente com a personagem principal, aprofundando a figura desta. Nikolai Stepánovitch, na atmosfera de cortês hipocrisia aceita, como que se duplica. Como espelhos, que reflitam um ao outro, Nikolai Stepánovitch e o seu visitante repetem as mesmas ações. O principal pronome usado no fragmento é "nós".

Nós já mostrámos como os pormenores cromáticos da roupa ligam o doutorando duma só vez com três personagens: Piotr Ignátiev, o criado Egor e Kátia. Mas, no fragmento da sua conversa com o professor, há mais um paralelo. Nikolai Stepánovitch grita duas vezes a palavra "venda":

- Pensam que isto aqui é uma venda? Eu não faço comércio de temas!...Isto aqui não é venda! (117) 
Essa réplica estende um fio até a uma personagem, que aparece momentaneamente nas recordações do professor:

Ali está a venda de secos e molhados; antigamente, pertencia a um judeuzinho, que me vendia cigarros... (107),

Tal fio une essa personagem ao jovem doutorando.

E, por fim, o estudante de Medicina. Não encontramos nenhum pormenor, que o ligue a outras personagens, nem situação, que lembre alguma análoga. Por que, então, foi posto na novela? Julga Kubássov que o protótipo desse jovem preguiçoso, no contexto de "Fausto", é o estudante de quem escarnece Mefistófeles.

$\mathrm{Na}$ nossa hipótese, analogamente ao professor recordar-se como seminarista, o próprio autor, com um tanto duma ironia verdadeiramente tchekhoviana, recorda a si próprio como estudante de Medicina. Infelizmente, há poucos testemunhos do tempo dos seus estudos na universidade, tanto nas reminiscências de contemporâneas, quanto nas suas próprias cartas. É sabido que, em verdade, Tchékhov, em todo o período universitário, nunca foi reprovado em exames e frequentou diligentemente todas as aulas e atividades laboratoriais ${ }^{111}$, contudo, o estudo nunca Ihe foi fácil: a literatura tomava tempo de mais. Por algumas referências à Medicina em cartas desses anos, pode ver-se como the era difícil combinar a atividade literária com as aulas e os exames:

Eu tenho agora... os exames finais... Repercutem no gato as lagrimazinhas do rato; do mesmo modo repercute em mim, agora, a minha incúria dos anos passados. Ai de mim! Impõe-se estudar quase tudo desde o começo. Para além dos exames (que, a propósito, ainda estão pela frente), estão às minhas ordens o trabalho em cadáveres, atividades de clínica com as inevitáveis histórias de morbo, a ida a hospitais... Trabalho e sinto a minha impotência. A memória ficou ruim para decoreba [decoração], fiquei mais velho, a preguiça, a literatura... vós cheirais a vodca etc. Vontade de descansar, mas ... o verão ainda está tão longe!

${ }^{111}$ SUKHIKH, I. Tchékhov v Jizni (Tchékhov na vida). Moscou, Ed. "Vremia"'", 2010, p.90 
(112).

No entanto, nesse episódio, o mais importante é outra coisa; nele, sente-se uma clara nostalgia pelos anos pândegos de estudante, com festas ruidosas após a meia-noite, bebedeira, a ida regular a teatros, romances juvenis e, infelizmente, a "dor de cabeça" à véspera de exames. Tal é a vida, fora do âmbito do trabalho tenso, que o próprio Tchékhovestudante vivera (do que se tem, a propósito, uma grande quantidade de testemunhos), aquela acerca da qual o professor com muito prazer escutaria falarem.

Segue-se um silêncio. Levanto-me, espero que o visitante se vá, mas ele fica parado, olha para a janela, puxa um pouco a barbicha e pensa.

A voz do sanguíneo é agradável, cheia, os olhos inteligentes, zombeteiros, o rosto bonachão, um pouco amassado pelo uso frequente de cerveja e pelas longas horas deitado no divã, ele poderia contar-me muito de interessante sobre a ópera, sobre as suas aventuras amorosas, sobre os colegas de que ele gosta, mas infelizmente, não se costuma falar sobre isso. (116)

Nota-se claramente com que simpatia é feito o retrato desse sanguíneo, em cuja aparência se reconhecem traços do próprio autor: os olhos inteligentes e zombeteiros, o baixo profundo e a barbicha. ${ }^{113}$.

Até numa história tão "enfadonha", encontrou-se lugar para o suave humor tchekhoviano.

Como pode ver-se, todas as personagens, das principais às apresentadas só de passagem, a par de outros elementos da composição, relacionados com o enredo, a semântica e a estilística, duma forma ou de outra, revelam-se entrelaçadas umas com as outras, e cada qual delas constitui um fragmento do quadro uno e inconsútil, desenhado por Tchékhov.

\footnotetext{
112 Carta ao irmão Aleksandr Tchékhov, entre 15 e 28 de Outubro de 1883.

${ }^{113}$ Carta a N. A. Liéikin, de 25 de Dezembro de 1883.
} 


\subsection{Cronótopo}

À essencial interligação das relações temporais e espaciais, aproveitadas artisticamente pela literatura, chamaremos cronótopo (M. Bakhtin 15)

Separando o pessoal, referente à personagem principal e ao seu nome, e o tempo e o espaço históricos e mitológicos e analisando o funcionamento da "palavra alheia" (citações, alusões, reminiscências) e pormenores "fortuitos", nós acompanhámos a formação do cronótopo da novela, o qual produz o eixo de toda a composição da obra.

O tempo pessoal de Nikolai Stepánovitch é, em primeiro lugar, a extensão da escrita dos apontamentos, de três a quatro meses e facilmente determinada por sinais do texto. Bem no início, mencionam-se peliças e luvas; consequentemente, a estação do ano é o Inverno; a personagem diz que não Ihe resta mais do que meio ano de vida. Em seguida, "chega o Verão", e ela supõe que morrerá dentro de três meses. Em segundo lugar, a sua vida passada, traçada pelas recordações, das primeiras, referentes à infância e mocidade, passando pelo período de formação da personagem, até ao presente, até ao momento em que ela se põe a escrever a sua confissão, isto é, os sessenta e dois anos vividos. $E$, finalmente, o futuro, próximo e distante, que se encontra além dos limites da sua vida. Nikolai Stepánovitch conjectura se Kátia estará no seu funeral, qual será a sua sepultura, quem lecionará no seu lugar e o que será da Ciência.

Mas o mais importante de tudo é a sua sensação interior do tempo, com a qual ele vive e a qual impregna o estado de espírito do seu diário: a vida flui monotonamente, sempre igual e desprovida de sentido, ao passo que os preciosos últimos meses, dias e minutos passam impetuosamente.

No texto, encontram-se praticamente todas as categorias temporais existentes: segundo, minuto, quarto de hora, meia hora, hora, 
dia, semana, mês, ano, século, eternidade, toda a vida, passado, futuro (por exemplo, minuto aparece 20 vezes; hora - 28; ano - 38 e assim por diante).

Ademais, é preciso saber o que se pretende, e vigiar tudo atiladamente, não perdendo por um instante sequer o campo visual. (111)

Кроме того, надо быть человеком себе на уме, следить зорко и ни на одну секунду не терять поля зрения. ${ }^{114}$

Não dormir de noite significa ter consciência, a cada momento, de ser anormal...(103)

Не спать ночью - значит, каждую минуту сознавать себя ненормальным... ${ }^{115}$

Discorre um quarto de hora, meia hora, e eis que, observa-se, os estudantes começam a olhar para o teto...(112)

Apenas ele acaba de gritar, já sei que uma hora depois, embaixo, o porteiro há de acordar ... (103)

O meu dia começa com a vinda de minha mulher. (103)

Há muito tempo já que Mikhail Fiódorovitch devia ter viajando para estrangeiro, mas ele adia a partida a cada semana. (151)

Pagar dez rublos por mês é muito mais fácil que entregar de uma vez cinquenta. (105)

Antes de passar meio ano, recebi uma carta atualmente eufórica e poética. (121)

Faz um ano que estamos de relações tensas. (115)

É melhor perder cinco anos ... (116)

Há trinta anos já que dá as suas aulas...(133)

...a alma dessa infeliz não conheceu e não há de conhecer abrigo a vida toda, toda! (161)

A ciência, graças a Deus, já viveu o que tinha de viver. (137)

${ }_{114}^{11}$ A. Tchékhov, Moscou,1977, p. 261

115 ------------------------------ p.254 
Наука, слава богу, отжила свой век.$^{116}$

Com a minha disposição atual, bastam cinco minutos para que ele me enjoe como se eu o tivesse visto e ouvido durante uma eternidade.

...mas o que ela conserva do passado é apenas o temor pelo minha saúde. (104)

Imagino nitidamente o seu futuro. (110)

Encontram-se, mais de uma vez, a palavra "tempo" e o léxico semanticamente relacionado a ela:

Passa um longo período de tempo penoso... (103)

Com a graça de Deus, com o tempo, há de se empregar em alguma parte. (129)

Você, minha amiga, tem horas vagas demais. (150)

Ao mesmo tempo, é preciso fazer de si cientista, um pedagogo, um orador... (112)

$E$, antes, eu nunca soube conformar-me como agora com a lentidão do tempo. (157)

No sexto e último capítulo, por meio da repetição da própria palavra "последний" ("último"), acentua-se (o que, infelizmente, nesse caso, quase se perde na tradução) o facto de que o tempo de vida do narrador está a terminar:

os últimos dias da minha vida serão inatacáveis mesmo [correto: pelo menos - E. $\boldsymbol{V}$.] pelo lado formal. (156)

последние дни моей жизни будут безупречны хотя с формальной стороны. ${ }^{117}$

Ademais absolutamente tanto faz para onde viajar, para Khárkov, Paris ou Biérditchev (156)

К тому же в последнее время я так оравнодушел ко всему, что мне положительно всё равно, куда ни ехать, в Харьков, в Париж ли, или в Бердичев. ${ }^{118}$

Os meses derradeiros da minha vida, enquanto espero a morte, parecem-me bem mais compridos que a toda a minha existência

${ }_{116}$ A. Tchékhov, Moscou,1977, p.286 
anterior (157)

Последние месяцы моей жизни, пока я жду смерти, кажутся мне гораздо длиннее всей моей жизни. ${ }^{119}$

eu ter ensombrecido os meses derradeiros da minha vida com pensamentos e sentimentos dignos dum escravo e bárbaro. (159) последние месяцы своей жизни я омрачил мыслями и чувствами, достойными раба и варвара, ${ }^{120}$

A tomada de consciência, pela personagem, da sua "existência" põe-se em correspondência com indicações exatas da hora do dia e da estação do ano e com quantos minutos, horas e anos se passaram desde este ou aquele acontecimento.

Indica-se não somente a idade da personagem principal, senão também a das outras. Nós ficamos a saber que Kátia tem 25 anos; Piotr Ignátievitch, cerca de 35; Hnekker não tem 30; Mikhail Fiódorovitch, cerca de 50; e Nikolai, 62. Cria-se a impressão de que, no subconsciente do professor, se faz um balanço permanente do tempo passado e em passagem, o que se salienta com ajuda da estilística e do ritmo, o qual ora diminui a sua marcha, ora a acelera, e com ajuda da antítese"antesagora" e do léxico correspondente (outrora; agora; no passado; lembrome; desde então).

Nikolai Stepánovitch vive no tempo corrente, que possui começo e fim e já tende ao seu termo; o professor dirige-se em pensamento, por um lado, ao futuro e à eternidade e, por outro, ao passado, idealizado, no qual a vida ainda não tinha perspectivas e não havia necessidade de meditar no valor de cada instante.

O espaço em que Nikolai Stepánovitch existe, é um bom tanto fechado: a esfera citadina (universidade, o seu lar, o apartamento de Kátia), a datcha (a sua e a de Kátia) e Khárkov (o quarto de hotel). Dias e anos (com a exceção de Khárkov), ele percorre os mesmos caminhos, vai aos mesmos sítios e convive com as mesmas pessoas. $O$ antigo conforto psicológico do lar e das paredes de casa torna-se uma rotina insuportável,

${ }^{119}$ A. Tchékhov, Moscou,1977, p.305

120 - 
e surge a necessidade de alguma mudança, que o impele a uma fuga constante, dum espaço a outro. Da universidade para casa, de casa para a de Kátia:

Certa força invisível e incompreensível empurra-me rudemente para fora de minha casa. (130)

Dali, uma vez que o estreito círculo se mantém fechado, novamente para casa. A mudança para a datcha revela-se a malograda esperança de que, com a mudança de espaço, também a vida mudaria. $E$ em Khárkov, realmente, sítio inteiramente novo para a personagem, ela apanha-se a pensar na absoluta irremediabilidade do que se passava. A mudança de espaço é apenas uma mudança de decoração, de cena; onde quer que esteja, aonde quer que vá, para onde quer que fuja, esteja ela cercada de gente ou não, ela em toda a parte vê-se sozinha consigo, com a sua doença, com os seus pensamentos, decepção e medo. E até a inesperada aparição de Kátia, que, aparentemente, poderia acabar com aquela surda e desesperada solidão, só agrava a situação e acrescenta nova dor. Fica claro que Kátia se encontra na mesma situação: a fuga, que Ihe parece salvação, não passa duma tentativa fadada ao malogro.

No entanto, no passado de Nikolai Stepánovitch, se julgarmos pelas suas recordações, não apenas o tempo, mas também o espaço, eram sentidos por ele como mais largos e mais abertos. Salienta-se isso por pormenores como os sons duma harmónica (sanfona) que lhe chegam de longe, a comparação do auditório estudantil a um mar, a mudança de cidades na viagem de Kátia.

E o cronótopo do "nome" da personagem principal ultrapassa em muito os limites do seu tempo e espaço pessoal. Vivo fora dos limites duma cidade e até do país, ele sobreviverá em muito à vida real da pessoa:

É membro de todas as universidades russas e de três estrangeiras. ... Esse meu nome é popular. Na Rússia, ele é 
conhecido por toda pessoa alfabetizada e, no estrangeiro, é citado do alto das cátedras, com o acréscimo: conhecido e respeitado (101)

...li a minha biografia até numa revista alemã... (157)

Agora o meu nome passeia tranquilamente por Khárkov; daqui a uns três meses, gravado em letras de ouro sobre a tumba, ele há de brilhar como o próprio Sol, e isso quando eu já estiver coberto de musgo... (160)

Como já mostrámos nos capítulos anteriores do nosso trabalho, com a indicação de datas concretas, nomes de pessoas reais, do país (já nos primeiros parágrafos da novela, menciona-se duas vezes a Rússia) e nomes de cidades, restabelecem-se facilmente o tempo histórico e o lugar dos acontecimentos: metade dos anos 1880, Moscou (menção a Gruber e Babúkhin, professores da Universidade de Moscou) e Khárkov. Já o tempo mitológico cria-se com a referência a heróis do folclore e à figura de Nikolai, o vigia da universidade.

Os estudiosos têm-se debruçado, nos últimos tempos, com cada vez mais frequência sobre a questão das relações intertextuais de Tchékhov, porém o tema é inesgotável e por isso permanece aberto. Os estudos tratam tanto do conjunto da obra do escritor quanto de obras isoladas; examinam-se inúmeros paralelos com textos literários famosos, a polémica com estes, a paródia a eles (feitas principalmente na fase inicial) e a referência a acontecimentos históricos e culturais e nomes; citam-se, sobretudo, textos bíblicos e nomes como Púchkin, Tolstói, Shakespeare e Goethe (V. Katáev, N. Kapústin, V. Kubássov, A. Sóbennikov e outros).

Não foi exceção "Uma história enfadonha". Ainda em vida de Tchékhov, notou-se a sua relação com "A morte de Ivan Ilitch", de Tolstói, e "O discípulo", de Bourget; mais tarde, estudou-se o diálogo com Goethe, Marco Aurélio e o Eclesiastes.

A atenção, nesses estudos, concentra-se nos aspectos semânticos e na dialogicidade de ideias, motivos, enredos e personagens. No entanto, nós acreditamos que as diversas inserções da "palavra alheia" 
no texto tchekhoviano, tais como as citações, as reminiscências e alusões (claras e ocultas), junto com a menção à História e a pessoas famosas, desempenham mais um papel: elas ampliam o tempo e o espaço artístico, formando o cronótopo.

Dispostos os meios supracitados em ordem cronológica (do mesmo modo como fizemos com as recordações da personagem), tem-se um quadro de toda a história humana, da remota Antigüidade ao fim do século $\mathbf{X X}$; reunidos em conjunto os pormenores fortuitos de caráter geográfico e naional, obtém-se um extenso mapa do mundo. Alguns exemplos:

Mundo Antigo (século 13 antes da nossa era - século 1 da nossa era).

Antigo Testamento:

Frequentemente, extasio-me vendo um menino e uma menina, ambos esfarrapados e de cabelos muito claros, treparem no muro do jardim e rirem da minha calva. Leio nos seus olhos brilhantes: "Veja, um careca!" (145)

Antigüidade: (séc. 6 antes da nossa era- séc 4 e 5 da nossa era).

E eu penso que Hércules, após a mais picante das suas proezas, não sentiu tão doce langor como o que eu experimentava depois de cada aula. (112)

Numa palavra, não tem nada a ver com Hécuba. (110)

- Epíteto (anos 50 -138 da n. e.)

- Marco Aurélio (anos 161 - 180 n.e) 
deixam-se influenciar facilmente pelos escritores mais recentes, mesmo de segunda classe, mas são de todo indiferentes a clássicos como Shakespeare, Marco Aurélio, Epícteto ou Pascal...(139)

-Idade Média (séc. 5-14):

A mulher moderna é tão chorosa e rude de coração como na Idade Média. (125)

A sarcástica frase "a Rússia ser invadida por exércitos chineses..." suscita uma associação com a invasão da Rússia pelas hordas tártaromongóis no século 13.

Época da Renascença (séc. 15-16):

Shakespeare (1564-1616)

...eu amei apaixonadamente pela sua inteligência lúcida e boa, pela alma pura, pela beleza e, como Otelo a Desdêmona, pela "compaixão em relação à minha ciência... (104)

Modernidade (séc. 16-17):

-Pascal (1623 - 1662)

Século 18: 
-Bach (1685-1750)

As mãos e Hnekker falam de fugas, contrapontos, cantores e pianistas, de Bach e Brahms...(128)

-Karamzin, "Pobre Lisa" (1792)

- De ninguém tenho tanta pena como da nossa pobre Lisa. (105)

\section{Século 19:}

-Está representado inteirinho por nomes e citações, a começar por Krylov (fábulas de 1808):

Assim aconteceu um dia, passei muito tempo olhando Hnekker com desdém e de repente, sem mais nem menos, soltei:

-"Sucede às águias descer mais que as galinhas.

-Mas estas nunca hão de subir às nuvens..." (147)

- Araktchéev (1769-1834):

...e então a minha visão do mundo pode ser resumida nas palavras do famoso Araktchéiev numa das suas cartas íntimas: "Tudo o que há de bom no mundo não pode existir sem ruim, e há sempre mais coisas ruins que boas" (142)

- Tchádski "Infelicidade devida ao espírito" (1823-1827): 
...quando ele procura convencer-me a todo custo de que Tchátzki, que conversava muito com imbecis e amava uma imbecil, era um homem muito inteligente... (120)

-Turguénev, "Diário dum homem supérfluo" (1849):

A cabeça e as mãos tremem-me de fraqueza; o pescoço, a exemplo de uma heroína de Turguiêniev... (102)

- Nekrássov (1821-1877)

- Kaviélin (1818 -1885)

- Pirogov (1810-1881)

- Skóbelev (1843-1882)

\section{Século 20:}

Não sei o que será daqui a cinquenta ou cem anos...(120) Gostaria de acordar daqui a uns cem anos e espiar, ao menos com um olho, o que será da ciência. (159)

Como pode ver-se, um alargamento extraordinário dos limites temporais: do século 13 antes da nossa era ao fim do século 20 da nossa era.

Com isso, a palavra história adquire um significado especial no título da novela.

$\mathrm{Na}$ narrativa, está entrelaçada uma grande quantidade de nomes de países e cidades, reminiscências-associações (Hékuba-Grécia), Marco Aurélio-Roma, Shakespeare-Inglaterra, Patti-Itália etc.) e pormenores de caráter geográfico:

Geralmente, ela está lendo, deitada sobre o divã turco ou o sofá. (131) 
Mas eis que percorremos a escada, depois o corredor escuro, com uma janela italiana, e entramos no quarto de Lisa. (153)

e nacionalidades:

Todas essas notícias se parecem e podem ser reduzidas ao seguinte tipo: um francês fez uma descoberta, outro, um alemão, pilhou-o em flagrante, demonstrando que essa descoberta já fora feita em 1870 por certo americano, e um terceiro, igualmente alemão, foi mais esperto que ambos, demonstrando-lhes que eles cometeram uma gafe, confundindo, sob o microscópio, bolinhas de ar com o pigmento escuro. (146)

Provavelmente, a Patti podia cantar-Ihe bem junto ao ouvido, a Rússia ser invadida por exércitos chineses, ocorrer um terremoto, e ele não moveria um membro sequer, continuando calmamente a olhar em seu microscópio, o olho entrecerrado.(110)

...mas assim mesmo não compreendo a sua presença; ela desperta em mim a mesma perplexidade que se fizessem um zulu sentar-se à mesa comigo. (126)

Desse modo, se fizermos um balanço, nas páginas da novela, encontraremos, claramente ou às ocultas, por associação, a Rússia, Varsóvia, Khárkov, Ialta, Ufá, a Criméia, o Cáucaso, o Volga, Biérditchev, a Europa, a Alemanha, a Inglaterra, a França, a Itália, a Grécia, a China, a América e a África (zulu). Todas essas menções não possuem importância sob o aspecto do enredo ou dos motivos e são, em essência, "fortuitos", e lembram intuitivamente que, para além do lugar principal da ação, no qual 
o professor escreve os seus apontamentos, existe um mundo inteiro.

Costuma-se dizer que o homem precisa só de pouco mais de dois metros de terra. Mas, ora, esse pouco mais de dois metros é necessário a um cadáver, não a um homem. O homem precisa não desse pouco mais de dois metros de terra, não duma herdade, mas do globo terrestre inteiro, de toda a natureza, onde, no vasto espaço livre, ele possa manifestar todos os traços e peculiaridades do seu espírito livre. ${ }^{121}$

Nós vemos que o espaço, limitado por Moscou, pela datcha ao pé dessa cidade e Khárkov, e o tempo, resumido a três-quatro meses e uma vida humana (pelas recordações), nos apontamentos de Nikolai Petróvitch, feitos na própria novela (acompanhando a ideia do autor), alargam-se incomensura-velmente e abarcam quase "todo o globo terrestre" e toda a história da Humanidade.

Assim, um "acontecimento individualizado" adquire dimensão global. Tais "histórias enfadonhas" aconteceram e acontecerão sempre, independente-mente de época, em qualquer ponto da Terra.

Semelhante modo de formação do cronótopo literário é um procedimento importantíssimo de Tchékhov. Em relação a isso, podemos lembrar o conhecido mapa da África no gabinete de Voinítski ("Tio Vánia"), que motiva discussões até hoje no mundo científico, e a enfatizada interrelação entre o passado e o presente em "Luzes" e "O estudante" e o futuro irrealmente distante em "A gaivota" .

Há já milhares de séculos a terra não carrega em sua superfície nenhuma criatura viva... ("A gaivota", tradução nossa).

${ }^{121}$ A.TCHÉKHOV, Moscou, 1977, p.58. 
O estudante novamente pensou que, se Vassilissa chorara e a filha dela ficara desconcertada, então, claramente, o que ele acabara de contar e que acontecera dezanove séculos antes, tinha relação com o presente - com ambas as mulheres e, provavelmente, com aquela aldeia deserta, com ele próprio, com todas as pessoas... O passado, pensava ele, está ligado com o presente por uma corrente ininterrupta de acontecimentos, decorrentes um do outro. E pareceu a ele que ele acabara de ver as duas extremidades dessa corrente: tocara uma, e a outra tremera. ("O estudante", tradução nossa). 


\section{Conclusão}

O princípio da objetividade da narrativa, como basilar para a poética de Tchékhov do final dos anos de 1880 e começo dos de 1900, exigia um novo tratamento, uma nova expressão da posição autoral no texto. Da confissão da personagem transparece uma visão de mundo do próprio escritor, o qual, propondo de modo não impertinente nem obsessivo uma multivariedade de tratamentos das suas obras, emprega sutilíssimos sinais, ocultos nas profundezas do texto, para o diálogo com o leitor, contando com a intuição, a experiência e o faro literário deste.

A fusão do concreto e tangível com o inconstante e condicional, do individual com o genérico e do efêmero com o eterno equilibra, segundo as suas próprias palavras, todos "os prós e contras", criando um mundo simbólico com mais de um sentido mas, ao mesmo tempo, real, reconhecível e irreal.

E, com auxílio duma arquitectónica ordenada, rigorosamente regulada, Tchékhov consegue uma insuperável harmonia na representação desse mundo, agindo tanto na consciência, quanto, como a música ou a poesia, no subconsciente do leitor.

$\mathrm{Na}$ novela estudada por nós, ele enfatiza de modo muito claro precisamente a estrutura, o arranjo, colocando a própria palavra "composição", bem como a palavra "final", nos lábios da persona-gem e entreabrindo a cortina dum trabalho artístico bem pensado e, simultaneamente, guiado pela inspiração e pela intuição na cenarecordação duma conferência ministrada pelo professor.

Cada qual dos elementos do sistema estudado por nós na novela "Uma história enfadonha" por si só basta a si e possui uma dinâmica e o seu próprio sentido, e, com isso, como assinalámos, todos eles como que dialogam entre si, formando um todo uno no nível do subtexto, um novo campo de sentidos subordinado ao desígnio geral do autor, sobre cuja base está a antítese "História-indivíduo" , refletida já no título e no subtítulo, o conflito, o contraponto entre a finitude da vida individual e o fluxo do tempo e do espaço. 


\section{Bibliografia}

\subsection{Obras de A. P. Tchékhov}

TCHÉKHOV, Anton. Sobranie sotchinenii i pisem v 30tomax Moscou: Nauka, 1974, v.1

Moscou: Nauka, 1975, v.2

Moscou Nauka, 1975, v.3

Moscou: Nauka, 1976, v.4

Moscou: Nauka, 1976, v.5

Moscou: Nauka, 1976, v.6

Moscou: Nauka, 1977, v.7

Moscou: Nauka, 1977, v.8

Moscou: Nauka, 1977, v.9

Moscou: Nauka, 1977, v.10

Moscou: Nauka, 1978, v.11

Moscou: Nauka, 1978, v.12-13

Moscou: Nauka, 1978, v.14-15

Moscou: Nauka, 1979, v.16

Moscou: Nauka, 1980, v.17 
Moscou: Nauka, 1982, v.18

TCHÉKHOV, Anton Sobranie sotchinenii i pisem v 30tomax. (Cartas.) 19-30v Disponivel em: http://ruslit.traumlibrary.net/book/chekhov-pss3021/chekhov-pss30-21.html

TCHÉKHOV, Anton. Zapisnyie knijki, Moscou: Vagrius, 2000

TCHÉKHOV, Anton. "A dama do cachorrinho" e outros contos. São Paulo: Editora 34, 2011, 4a ed. Tradução de Boris Schnaiderman.

TCHÉKHOV, Anton. "O beijo" e outras histórias. São Paulo: Editora 34, 2010, 3a ed. Tradução de Boris Schnaiderman

TCHÉKHOV, Anton. Teatro I. A Gaivota, O tio Vania, Veredas, 2009. Tradução de Gabor Aranyi

ANGELIDAS, Sophia (tradutora). A.P. Tchékhov: Cartas para uma poética. São Paulo: edusp, 1995

ANÍKIN, Andrei "Tiema málienkovo tchelovieka v rússkoi klássike". IN: PETRIENKO, L., Aníkin, A., Gálkin, A. Tiémy rússkoi klássiki. Utchébnoe possóbie. (Temas da clássica russa. Manual de estudos). Moscou: Prometei, 2000.

\subsection{Obras gerais}

ANGELIDES, Sophia. Anton P. Tchékhov: Cartas para uma Poética. São Paulo: Edusp, 1995

AURÉLIO, Marco. Meditações, São Paulo:Editora Martin Claret, 2012. Tradução Alex Marins

BAKHÁNEK, S. "Skutchnaja istoria" A.P.Tchékhova $v$ svete fenomena ponimánia. Moscou,2002

BAKHTIN, Mikhail. Questões de literatura e estética. São Paulo: Annablume/ Hucitec, 2002.

BAKHTIN, Mikhail. Fórmy vrémeni i khronotópa $\mathbf{v}$ románe. IN: BAKHTIN, M. Voprosy literatury i estetiki. Moscou:Khudojestvennaia literatura, 1975

BAKHTIN, Mikhail. Estética slovésnogo tvórchestva. Moscou:Iscusstvo, 
1986

BALABÁNOVICH, Evgeni. Tchékhov i Tchajkovski. M.Moscou:Moskovski rabotchii, 1975

BALUKHÁTY, S. Ránni Tchékhov IN: Vopróssy poétiki . Leningrado: Izdátelstvo LGU, 1990

BÉRDNIKOV, Georgiy. A.P. Tchékhov. Idéinyie i tvórtcheskie iskánia. Moscou:Khudozhestvennaja literatura, 1984

BOGDÁNOV V. Labirínt stseplenii, Moscou: Detskaia literatura, 1986

DEMÍDOVA T. Probléma ottchujdénia lichnosti $v$ povesti A.P.Tchékhova "Skútchnaia istória"// Gumanitarnye nauki $v$ sfere sovremennyx problem. Komsomol'sk-na-Amure, 2001, p.80-83

DÓBIN, Evgenij. Siujét i deistvitel'nost'. Iskusstvo detali. Leningrado:Sovetskij pisatel, 1981

ÉIGES I. Múzyka u Tchékhova-beletrista Disponivel em:http://www.opentextnn.ru/music/Perception/?id=6118

ÉIGES I. Múzyka v jizni i tvórtchestve Tchékhova. Moscou: Muzgiz, 1953

EIKHENBÁUM, B. O Tchékhove. O proze. Leningrado: Khudójestvennaia literatura. Leningrádskoe otdelenie, 1969.

FILÁT T. Osóbennosti semántiki, kompozítsii i fúnktsii finála "Ognéi" A.P.Tchékhova.

Disponivel

em:http://phil.duan.edu.ua/images/stories/Files/2014/ARTICLES_11/19.p df

FÓKIN, P. (Comp.) Tchékhov bez gliántsa. SanktPeterburg:Amfora, 2010

FORTUNÁTOV, Nicolay. Puti iskánii. 0 masterstvé pisatelia. Moscou:Sovetskij Pisatel, 1975

FRANCKOVIÁK, Malgozhata. Problémy kompozitsii, fábuly v póvesti L.N.Tolstógo "Smert' Ivána Il'icha i povesti A.P.Tchékhova "Skútchnaja istoria"sravnitel'nyi analiz.Disponivel em:

http://bazhum.muzhp.pl/media//files/Studia_Rossica_Posnaniensia/Studia _Rossica_Posnaniensia-r1979-t12/Studia_Rossica_Posnaniensia-r1979t12-s57-68/Studia_Rossica_Posnaniensia-r1979-t12-s57-68.pdf 
GolovatChÉVA, Alla (Ed.) Mir Tchékhova. Prostránstvo i vrémia, Dolya, Simferopol:Dolya, 2010

GOLOVATCHÉVA, Alla (Ed.) Tchékhov I Tolstoj: K 100-letiu pámiati L.N.Tolstógo. Simferopol:Dolya, 2011

GOLOVATCHÉVA, Alla (Ed.) Tchékhovskie tchténia v Jalte. Tchékhov segódnia. Moscou: dom-muzej tchékhova v Jalte, 1987

GRÓMOV, Mikhail. Realizm A.P.Tchékhova vtorói poloviny 80 godóv. Rostov-na-Donu: Rostovskoe knizhnoe izdatelstvo, 1958

GRÓMOV, Mikhail. Etiúdy o Tchékhove, Rostov-na-Donu: Rostizdat, 1951

GVOZDÉI, V. Sekréty tchékhovskogo khudójestvennogo téksta. Astrakhan: Izdatel'stvo Astraxanskogo gosudarstvennogo pedagogicheskogo universiteta, 1999

JURAVLÉVA, A. Óbchtchnost vospominánii geróev v struktúre khudójestvennogo mira proizvedénia (I.S.Turgiénev, L.N.Tolstoj, IN: Molodye issledovateli Tchékhova.5: Materialy mezhdunarodnoi nauchnoi konferentcii. Moscou: izdatel'stvo Moskovskogo Gosudarstvennogo Universiteta, 2005, p.152-159

KATÁIEV, Vladimir. Tchékhov i ego literatúrnoe okrujénie (80-e gódy XIX vieka). Spútniki Tchékhova. Moscou:Izdátelstvo Moskóvskovo universitiéta, 1982.

KATÁIEV Vladimir. Slójnost prostotý. Moscou:Izdátelstvo Moskóvskovo universitieta, 1998

KATÁIEV , Vladimir (Ed.) Tchékhovski véstnik, Moscou: Literaturnyj muzey, 2016, v.33

KATÁIEV , Vladimir (Ed.) Tchékhovski véstnik, Moscou: Literaturnyj muzey, 2017, v.34

KATÁIEV, Vladimir. Próza Tchékhova: problémy interpretátsii. Disponivel em:http://www.chekhoved.ru/index.php/library/chekbovbooks/114-kataev

KATÁIEV , Vladimir (Ed.)Tchékhoviana. Tchékhov v kultúre XX véka. Moscou: Nauka, 1993

KIBÁLNIK S.(Ed.)Obraz Tchékhova I tchékhovskoi Rossii v sovreménnom mire. Sankt-Petersburgo: ID "Petropolis", 2010 
KHRÁMOVA, S. o muzykálnosti kompozitsii literatúrnykh proizvedénii. Disponivel em:http://duan.edu.ua/uploads/vidavnitstvo15-16/13390.pdf

KHUDJÍNSKA-PARKOSÁDZE, Anna. Fenomén pámiati v tvórtchestve Antona Tchékhova.

Disponivel em:http://bazhum.muzhp.pl/media//files/Studia_Rossica_Posnaniensia/St udia_Rossica_Posnaniensia-r2012-t37/Studia_Rossica_Posnaniensiar2012-t37-s33-44/Studia_Rossica_Posnaniensia-r2012-t37-s33-44.pdf

KLEKH, I. Tchetýrejdy Tchékhov. Moscou: Emergency Exit, 2004

KOJÉVNIKOVA, N. Stil' Tchékhova. Russkaia retch, 2013, n.1 Disponivel em:http://russkayarech.ru/files/issues/2013/1/22-kozhevnikova.pdf

KOJÉVNIKOVA, N. Povtór kak spósob izobrajénia personájei v prose A.P.Tchékhova. Disponivel em:https://www.ereading.club/chapter.php/114034/7/Literaturnyii_tekst_Problemy_i_meto dy_issledovania._IV_\%28Sbornik_nauchnykh_trudov\%29.html

KOJUBÓVSKAIA, G.(Ed.) A.P.Tchékhov: variánty interpretátsii.(Sbornik naúchnykh statej) Барнаул : БГПУ, 2007Barnaul: Barnaulskij Gosudarstvennyj Pedagogicheskij universitet, 2007, v.1

KÓROBOV, Vladimir. Putechéstvie k Tchékhovu, Moscou: Chkola-Press, 1996

KÚZICHEVA, A. (Ed.)Tchékhoviana. Stat'i, publikátsii,esse. Moscou:Nauka, 1990

KUZNETSÓV C. O fúnktsiiakh remárki v tchékhovskoi dráme, Russkaia literatura, $\mathrm{n}$ 1., 1985

LAKCHÍN, Vladimir. Tolstói i Tchékhov. Moscou: Sovetskii pisatel', 1975

LARIÓNOVA, M. (Ed.) Tvórtchestvo A.P.Tchékhova: tekst, kontekst, intertekst. 150 let so dnia rozdenia pisatelja.Sbornik materialov Mezdunarodnoi nautchnoi konferentsii. (Rostov-na-Donu, 1-3 oktiabria 2010)Rostov-na-Donu:NMC "Logos",2010.

LÉBEDEV, A. Individuálnaia sub'iektivnost $\mathbf{v}$ poétike Tchékhova. Utchenye zapiski Kazanskogo gosudarstvennogo universiteta, 2006, v. 148

LÉLIS, E. Filologítcheskoe tolkovánie khudójestvennogo téksta kak poisk podtékstovykh smýslov ( $\mathrm{Na}$ materiale rasskáza A.P.Tchékhova "Tchérny monákh").

Vestnik Udmurtskogo universiteta, 2008, n.3, p.123 
LÉLIS, E. K probléme vidov podtéksta $v$ rasskáze A.P.Tchékhova "Spat" khóchetsia"

Vestnik Udmurtskogo universiteta, 2011, n.2, p.146

LÉLIS, E. Slóvo i podtékst v rasskáze Tchékhova "Arkhieréi". Disponivel

em:http://www.unn.ru/pages/issues/vestnik/99999999_West_2009_6(2)/ 50.pdf

LINKÓV, Vladimir. Tcheloviék pered litsóm jizni (o tvórtchestve A.P.Tchékhova) Istorija russkoj literatury XIX veka $v$ ideiax.Moscou:Izdátelstvo Moskóvskovo universitieta, 2002

LINKÓV, Vladimir. Khudójestvennyi mir prózy Tchékhova, Moscou: Izdátelstvo Moskóvskovo universitieta, 1982.

LIPOVÉNKO, E. (Ed.)Litchnaia bibliotéka Tchékhova: literatúrnoe okrujénie i epókha. IN:Sbornik materialov Mejdunarodnoi nauchnoi konferentsii. (Taganrog, sentiabr 2015). Rostov-na-Donu: Foundation, 2016.

LICHÁEV,S. A.P.Tchékhov: kritika býta kak presentátsia bytiá. (Obraz Tchékhova $v$ prostranstve metafiziki). Disponivel em:http://www.phil63.ru/a-p-chekhov-kritika-byta-kak-prezentatsiyabytiya

LICHÁEV, S. A.P.Tchékhov: Jizn' duchi v zérkale sostoiánii. ( $K$ analizu effekta neopredelennosti $v$ proizvedeniakh A.P.Tchékhova. Disponivel em:http://www.phil63.ru/a-p-chekhov-zhizn-dushi-v-zerkale-sostoyanii

LICHÁEV, S. Vyrazítel'nost' nevyrajénia. (O metafizitcheskom smysle "sderjannosti" i"pauzy" V "mire" A.P.Tchékhova). Disponivel em:http://www.phil63.ru/ap-chekhov-vyrazitelnost-nevyrazheniya

MAMÉDOVA T. Ritmomelodítcheskaia organizátcia opisánii priródy v póvesti A.P.Tchékhova "Step"". Disponivel em:https://studwood.ru/1279097/literatura/mamedova_ritmomelodichesk aya_organizatsiya_opisaniy_prirody_povesti_chehova_step

MEERKHÓLD, Vsevolod. Stat'i, pís'ma, rétchi, besédy.Moscou:"Iskusstvo" 1968

MELETÍNSKI Eliasar. Ot mifa $\mathbf{k}$ literatúre. Moscou: Rossíiski gossudárstvennyi gumanitárnyi universitet, 2001

MORUÁ, AnrI Literatúrnye portréty. Moscou: "Pressa" , 1992 
NIKÓLINA N. Temporál'naia organizátsia finálov v p'ésakh A.P.Tchékhova. Disponivel em:http://www.docme.ru/doc/1624359/temporal._naya-organizaciyafinalov-v-p._esah-a.-p.-chehova.pdf

NUMM, Elena. Téma "bolézni" $\mathbf{v}$ próze i perepiske A.P.Tchékhova 1890-yx godov.Toronto Slavic Quarterly. Disponivel em: http://sites.utoronto.ca/tsq/13/nymm13.shtml

ODÉSSKAJA, Margarita. Tchékhov i probléma ideala, Moscou:Rossijskij gosudarstvennyj gumanitarny universitiet, 2011

OPÚLSKAJA, L. (Ed.) Tchékhov I Lev Tolstoi, Moscou: Nauka, 1980

ÓSUCH, Tadeuch. Zvúki múzyki kak srédstvo otkrýtia nóvogo mira v izbrannykh rasskázakh A.P.Tchékhova. Disponivel em:http://www.arch.apsl.edu.pl/polilog/pliki/nr2/08.pdf

PAPÉRNY, Zinovii. Táina sia... Moscou:BSG-press, 2002

RAZUMÓVA, N. Tvórtchestvo A.P.Tchékhova v aspékte prostránstva. Disponivel em:http://elib.tomsk.ru/purl/1-576/

RÉINFILD, Donald. Jizn' Antóna Tchékhova. Moscou:B.S.G.-press, 2007

SCHNAIDERMAN, Boris. "Prefácio". IN: A. Tchékhov. "O beijo" e outras histórias. São Paulo: Editora 34, 2010, 3a ed. Tradução de Boris Schnaiderman.

SCHNAIDERMAN, Boris. Tradução: ato desmedido. São Paulo: Perspectiva, 2011.

SEMÉNOVA, M. Tchékhov- khudójnik. Moscou: Prosvewenie, 1976

CHOSTAKÓVITCH, Dmitry. Vospominánia. Disponível em:http://tapirr.livejournal.com/1016995.html

SOBÉNNIKOV, Anatoli. Ecclesiástskie motivy $v$ póvesti A.P. Tchékhova "Ogni". (Motivos de Ecclesia na novela A.P. Tchékhova "Os luses"). Sibirski filologitcheski jurnal, n.3, 2016

SOBÉNNIKOV, Anatoli (Ed.).Filosófia A.P.Tchékhova. Materialy Mejdunarodnoi nautchnoi konferentsii (Irkutsk 27 iunia-2 iulia 2006). Irkutsk:Izdatel'stvo Irkutskogo gosudarstvennogo universiteta, 2008.

STEPÁNOV, I. O sub'ektivizátsii tchékhovskogo povestvovánia. Russkaia literatura, 2001, n.4, p.16-31 
SUKHÍKH I. Problémy poétiki A.P.Tchékhova, Leningrado: Izdátelstvo LGU , 1987

SUKHÍKH I. Tchékhov $\mathbf{v}$ jizni. Siujéty dlia nebol'chógo rasskáza, Moscou:"Vremia",1975.

SUKHIKH I. S výschei tótchki zrénia...,Voprósy literatúry, Moscou, n. 1., p.150,1985.

SUKHIKH, I. (Comp.)A.P.Tchékhov: Pro et contra São-Petersburgo:Izvo Russkogo Khristianskogo gumanitarnogo instituta, 2002. $1 \mathrm{v}$.

SYKHIH, I. (Comp.)A.P.Tchékhov: Pro et contra São-Petersburgo:Iz-vo Russkogo Khristianskogo gumanitarnogo instituta, 2010. 2v.

SUKHIKH, I. (Comp.)A.P.Tchékhov: Pro et contra São-Petersburgo:Izvo Russkogo Khristianskogo gumanitarnogo instituta, 2016. 3v.

TCHÉKHOV, Aleksandr $\mathbf{v}$ gostiákh u bábuchki i déduchki...Disponível em: http://az.lib.ru/c/chehow_aleksandr_pawlowich/text_0070.shtml

TCHUBÁROVA V. "Skútchnaia istória" A.P.Tchékhova: ópyt interpretátsii. Disponivel em:http://www.philoljournal.sfedu.ru/index.php/sfuphilol/article/view/326/309

TCHUDAKÓV, Aleksandr. Poétika Tchékhova. Moscou:"Nauka", 1971.

TCHUDAKÓV, Aleksandr (Ed.)Tchékhoviana Iz veka XX v XXI. Itogi I ojidania. Moscou: Nauka, 2007

TCHUDAKÓV, Aleksandr(Ed.) Tchékhoviana. Tchékhov i serebrianny vek. Moscou:Nauka, 1996

TRUAIÁ Anry. Antón Tchékhov. Moscou:"Eksmo" 2004.

TIÚPA, V. Khudójestvennost' tchékhovskogo rasskáza. Moscou: Vyschaia chkola, 1989.

TYNIÁNOV, Iryj. Probliéma stikhotvórnovo iazyká . Moscou: KomKniga, 2007.

VDÓVIN A. A.P.Tchékhov, ópyt mifopoetitcheskogo soznánia. Barnaul, $2000 . \quad$ Disponível em:.http://samlib.ru/w/wdowin_a_n/chekhov.shtml

VELICHKO, E. Otsénotchnost' v jazykovói kartine mira A.P.Tchékhova. Seminar "Mir iazyka A.P.TchékhovaDisponivel em:http://www.philol.msu.ru/ rlc2010/abstracts/rlc2010_abstracts_sem2 
2.pdf

VETÓKHINA, V. Detal' $v$ rasskázakh Tchékhova. Vestnik VGU. Seria filologia, jurnalistika, 2004, n.2 Disponivel em:http://www.vestnik.vsu.ru/pdf/phylolog/2004/02/vetohina.pdf

XAINÁDI, Zoltan. Khudójestvennaia detál'. Disponivel em:http://lit.1september.ru/article.php?ID=200203005 